\title{
Analysis of Air-to-Air Heat Exchanger Performance Data Taken Under the Residential Standards Demonstration Program
}

M. K. Drost

June 1990

Prepared for the Bonneville Power Administration under a Related Services Agreement with the U.S. Department of Energy Contract DE-AC06-76RLO 1830

Pacific Northwest Laboratory Operated for the U.S. Department of Energy by Battelle Memorial Institute 


\title{
DISCLAIMER
}

This report was prepared as an account of work sponsored by an agency of the United States Government. Neither the United States Government nor any agency thereof, nor Battelle Memorial Institute, nor any of their employees, makes any warranty, expressed or implied, or assumes any legal liability or responsibility for the accuracy, completeness, or usefulness of any information, apparatus, product, or process disclosed, or represents that its use would not infringe privately owned rights. Reference herein to any specific commercial product, process, or service by trade name, trademark, manufacturer, or otherwise, does not necessarily constitute or imply its endorsement, recommendation, or favoring by the United States Government or any agency thereof, or Battelle Memorial Institute. The views and opinions of authors expressed herein do not necessarily state or reflect those of the United States Government or any agency thereof.

\author{
PACIFIC NORTHWEST LABORATORY \\ operated by \\ BATTELLE MEMORIAL INSTITUTE \\ for the \\ UNITED STATES DEPARTMENT OF ENERGY \\ under Contract DE-AC06-76RLO 1830
}

Printed in the United States of America

Available to DOE and DOE contractors from the

Office of Scientific and Technical information, P.O. Box 62, Oak Ridge, TN 37831; prices available from (615) 576-8401. FTS 626-8401.

Available to the public from the National Technical Information Service,

U.S. Department of Commerce, 5285 Port Royal Rd., Springfield, VA 22161.

NTIS Price Codes, Microfiche A01

Printed Copy

\begin{tabular}{cr}
\hline Price Code & Page Range \\
\hline A02 & $1-10$ \\
A03 & $11-50$ \\
A04 & $51-75$ \\
A05 & $76-100$ \\
A06 & $101-125$ \\
A07 & $126-150$ \\
A08 & $151-175$ \\
A09 & $176-200$ \\
A10 & $201-225$ \\
A11 & $226-250$ \\
A12 & $251-275$ \\
A13 & $276-300$ \\
A14 & $301-325$
\end{tabular}

\begin{tabular}{ll}
\hline Price Code & Page Range \\
\hline A15 & $326-350$ \\
A16 & $351-375$ \\
A17 & $376-400$ \\
A18 & $401-425$ \\
A19 & $426-450$ \\
A20 & $451-475$ \\
A21 & $476-500$ \\
A22 & $501-525$ \\
A23 & $526-550$ \\
A24 & $551-575$ \\
A25 & $576-600$ \\
A99 & $601-U p$
\end{tabular}




\section{ANALYSIS OF AIR-TO-AIR HEAT EXCHANGER PERFORMANCE OATA TAKEN UNDER THE RESIDENTIAL STANDAROS DEMONSTRATION PROGRAM}

M. K. Drost

Manuscript Completed: December 1987

Date Published: June 1990

Prepared for the Bonneville Power Administration under a Related Services Agreement with the U.S. Department of Energy Contract DE-ACO6-76RLO 1830

Pacific Northwest Laboratory Richland, Washington 99352 


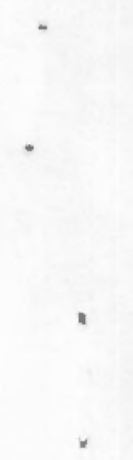




\section{SUMMARY}

The Bonneville Power Administration (BPA) initiated the Residential Standards Demonstration Program (RSDP) in 1983 to determine the costs and themal performance improvements associated with increased levels of themal integrity in new residences, as proposed by the Northwest Power Planning Council in their Model Conservation Standards (MCS). The program resulted in the construction of approximately 430 new residences, built to thermal performance standards, as dictated by the MCS in each of three climate zones in the region. A subset of the residences has been included in the End-Use Load and Consumer Assessment Program (ELCAP) being conducted by the Pacific Northwest Laboratory (PNL) for the Bonneville Power Administration (BPA). These structures are metered to record hourly energy consumption for several end-uses.

Many of the structures built to the MCS include air-to-air heat exchangers (AAHXs) to provide ventilation for maintenance of indoor air quality and comfort. Of the 71 MCS structures included in the ELCAP sample, 38 included air-to-air heat exchangers and had sufficient data to allow an analysis of both use patterns and thermal performance. This report describes the results of the analysis of the AAHX installations using the data collected as part of ELCAP.

The research had two objectives: to investigate AAHX use patterns and to determine the thermal performance of AAHX installations. The method used for analyzing use patterns consisted of determining the utilization of the AAHX, where utilization is defined as the ratio of actual AAHX energy consumption per time period divided by maximum AAHX energy consumption. Annual utilization was investigated by plotting daily average utilization as a time series. Daily utilization was investigated by determining the hourly utilization for a typical day.

Thermal performance was determined by selecting time periods with high utilization (implying nearly continuous AAHX operation). For these time periods, several thermal performance characteristics were deternined, including first law efficiency, temperature of the intake air (TIA) as it enters the living space and displaced space heating energy (Qsav). The calculation of the 
last two performance characteristics depended on knowing air flow rates through the AAHX. The ELCAP measurement protocols did not include measurement of air flow rates. Therefore, the best available information was one-time measurements of air flow made for each residence. To the extent that these values do not represent actual air flow for the time series data, errors will be introduced to the calculation of TIA and Qsav.

The results of the utilization analysis showed that there is substantial variation in AAHX utilization. The evaluation of AAHX annual utilization showed a range from almost continuous use to no use at all. Several archetypical patterns of annual utilization were identified. The average mean utilization for all 38 sites implied that the typical AAHX device would be operated approximately 7 hours per day, however, the standard deviation around the mean approximately equaled the mean value. This implied that a large variation in mean annual utilization did not appear to be influenced by either seasonal temperature variations or climate zones. Typical daily utilization values did not exhibit any dominant use patterns.

The investigation of thermal performance showed that latent heat effects (condensation of water vapor in the exhaust air stream) did not have a significant impact on thermal performance. The mean annual first law efficiency for the 25 available sites was determined to be $52 \%$, but there was a substantial standard deviation around the mean. Of the 25 sites, 11 had sufficient data to calculate the mean annual displaced space heating energy. This was $743 \mathrm{kWh} / \mathrm{yr}$ with a mean annual AAHX energy consumption of $220 \mathrm{kWh} / \mathrm{yr}$. Again, there was a large standard deviation around the mean values, suggesting a large variation in the mean values for the 11 sites.

In general, the investigations reported in this document show that mean annual AAHX utilization varies significantly between installations as do the daily use patterns. The thermal performance analysis tends to confirm results of previous investigators with the exception that this investigation seemed to show that latent heat effects are relatively important. 


\section{CONTENTS}

EXECUTIVE SUMMARY $\ldots \ldots \ldots \ldots \ldots \ldots \ldots \ldots \ldots \ldots \ldots \ldots \ldots \ldots \ldots \ldots \ldots \ldots \ldots \ldots \ldots \ldots \ldots \ldots$

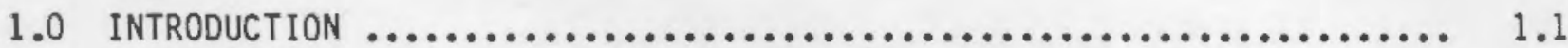

1.1 BACKGROUND $\ldots \ldots \ldots \ldots \ldots \ldots \ldots \ldots \ldots \ldots \ldots \ldots \ldots \ldots \ldots \ldots \ldots \ldots \ldots \ldots \ldots \ldots \ldots$

1.2 AIR-TO-AIR HEAT EXCHANGERS $\ldots \ldots \ldots \ldots \ldots \ldots \ldots \ldots \ldots \ldots \ldots \ldots \ldots \ldots \ldots \ldots \ldots$

1.3 ORGANIZATION OF REPORT $\ldots \ldots \ldots \ldots \ldots \ldots \ldots \ldots \ldots \ldots \ldots \ldots \ldots \ldots \ldots \ldots \ldots \ldots \ldots \ldots$

2.0 AIR-TO-AIR HEAT EXCHANGER OATA $\ldots \ldots \ldots \ldots \ldots \ldots \ldots \ldots \ldots \ldots \ldots \ldots \ldots \ldots \ldots$

2.1 AIR-TO-AIR HEAT EXCHANGER ELCAP DATA $\ldots \ldots \ldots \ldots \ldots \ldots \ldots \ldots \ldots \ldots . \ldots \ldots$

2.2 AIR FLOW DATA $\ldots \ldots \ldots \ldots \ldots \ldots \ldots \ldots \ldots \ldots \ldots \ldots \ldots \ldots \ldots \ldots \ldots \ldots \ldots \ldots \ldots \ldots \ldots$

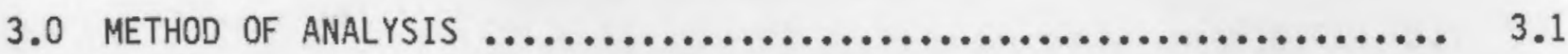

3.1 AIR-TO-AIR HEAT EXCHANGER USE PATTERNS $\ldots \ldots \ldots \ldots \ldots \ldots \ldots \ldots \ldots . . \ldots$

3.2 THERMAL PERFORMANCE ChaRACTERISTICS $\ldots \ldots \ldots \ldots \ldots \ldots \ldots \ldots \ldots \ldots . \ldots . \ldots . . . \ldots$

3.2.1 Sensible Heat Transfer Thermal Performance ........... 3.4

3.2.2 Latent Heat Effects $\ldots \ldots \ldots \ldots \ldots \ldots \ldots \ldots \ldots \ldots \ldots \ldots \ldots \ldots .3 .7$

3.2.3 Annual Performance Calculations ................. 3.7

3.3 ISSUES AFFECTING ANALYSIS TECHNIQUE $\ldots \ldots \ldots \ldots \ldots \ldots \ldots \ldots \ldots \ldots . . . . \ldots$

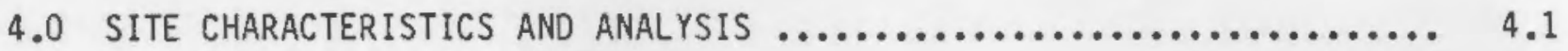

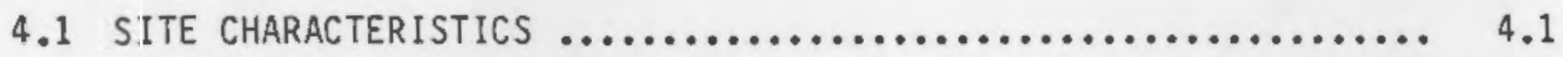

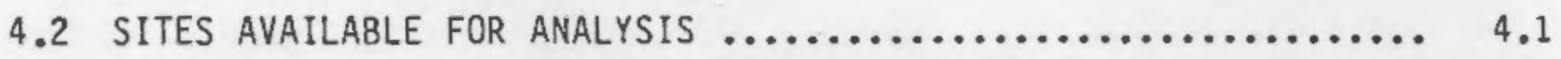

5.0 RESULTS OF THE AIR-TO-AIR HEAT EXCHANGER EVALUATION $\ldots \ldots \ldots \ldots \ldots \ldots . . . .$.

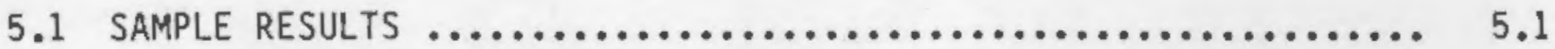

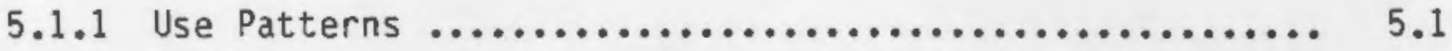

5.1.2 Sensible Heat Thermal Performance $\ldots \ldots \ldots \ldots \ldots \ldots \ldots \ldots . \quad 5.1$

5.1.3 Latent Heat Performance $\ldots \ldots \ldots \ldots \ldots \ldots \ldots \ldots \ldots \ldots \ldots . . \ldots . \ldots$

5.1 .4 Annual Performance $. . \ldots \ldots \ldots \ldots \ldots \ldots \ldots \ldots \ldots \ldots \ldots \ldots . \ldots \ldots$ 
5.2 UTILIZATION OF AIR-TO-AIR HEAT EXCHANGER UNITS $\ldots \ldots \ldots \ldots \ldots \ldots . .6 .6$

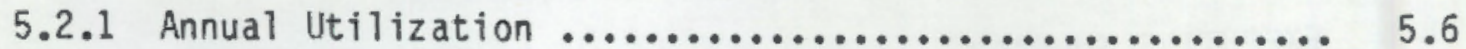

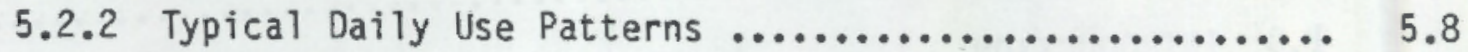

5.2 .3 Mean Utilization $\ldots \ldots \ldots \ldots \ldots \ldots \ldots \ldots \ldots \ldots \ldots \ldots \ldots \ldots . . . \ldots . \ldots$

5.3 MeAsures of THERMal PERformance $\ldots \ldots \ldots \ldots \ldots \ldots \ldots \ldots \ldots \ldots \ldots \ldots \ldots \ldots \ldots \ldots$

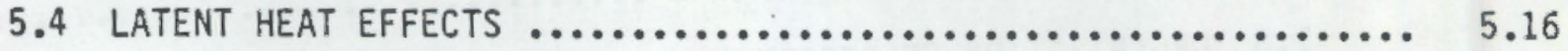

5.5 ANNUAL ENERGY CONSUMPTION $\ldots \ldots \ldots \ldots \ldots \ldots \ldots \ldots \ldots \ldots \ldots \ldots \ldots \ldots \ldots \ldots \ldots \ldots \ldots \ldots$

6.0 CONCLUSIONS $\ldots \ldots \ldots \ldots \ldots \ldots \ldots \ldots \ldots \ldots \ldots \ldots \ldots \ldots \ldots \ldots \ldots \ldots \ldots \ldots \ldots \ldots \ldots . \ldots \ldots$

6.1 CONCLUSIONS CONCERNING RESULTS $\ldots \ldots \ldots \ldots \ldots \ldots \ldots \ldots \ldots \ldots \ldots \ldots \ldots \ldots \ldots \ldots$

6.2 CONCLUSIONS CONCERNING ANALYSIS METHOD $\ldots \ldots \ldots \ldots \ldots \ldots \ldots \ldots \ldots . \ldots . \ldots . \ldots$

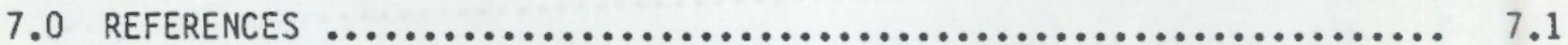

APPENDIX A - ANNUAL THERMAL PERFORMANCE OF INDIVIDUAL SITES $\ldots \ldots \ldots \ldots \ldots .1$

APPENDIX B - DEFINITION OF ID NUMBER $\ldots \ldots \ldots \ldots \ldots \ldots \ldots \ldots \ldots \ldots \ldots \ldots \ldots \ldots \ldots \ldots$ 


\section{FIGURES}

1.1 Schematic of Typical Air-to-Air Heat Exchanger $\ldots \ldots \ldots \ldots \ldots \ldots \ldots \ldots .2$

2.1 Typical Air-to-Air Heat Exchanger Instrumentation $\ldots \ldots \ldots \ldots \ldots \ldots \ldots$ 2.2

3.1 Daily Average Utilization for Site ID $41111-151 \ldots \ldots \ldots \ldots \ldots \ldots \ldots . . . .3$

3.2 Utilization for a Typical Day for Site ID $41111-151 \ldots \ldots \ldots \ldots \ldots \ldots$

3.3 Characteristics of a Box Plot $\ldots \ldots \ldots \ldots \ldots \ldots \ldots \ldots \ldots \ldots \ldots \ldots \ldots \ldots \ldots . \ldots \ldots$

4.1 Climate Zone $\ldots \ldots \ldots \ldots \ldots \ldots \ldots \ldots \ldots \ldots \ldots \ldots \ldots \ldots \ldots \ldots \ldots \ldots \ldots . \ldots \ldots . \ldots \ldots$

5.1 First Law Efficiency as a Function of $\Delta T$ for Site IO $41111-151 \ldots \ldots .2$

$5.2 Q_{S a v}$ as a Function of $\Delta T$ for Site ID $41111-151 \ldots \ldots \ldots \ldots \ldots \ldots \ldots \ldots$

5.3 Supply Air Temperature as a Function of $\Delta T$

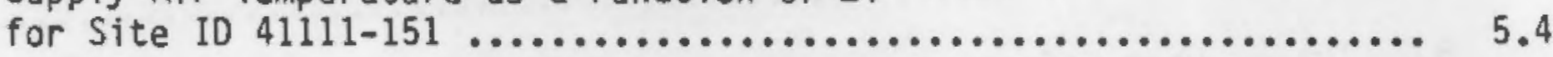

5.4 Daily Average Utilization for Site $41311-189$................. 5.8

5.5 Daily Average Utilization for Site $41111-217 \ldots \ldots \ldots \ldots \ldots \ldots \ldots \ldots \ldots$

5.6 Daily Average Utilization for Site 11211-136 ................ 5.10

5.7 Daily Use Pattern for Site $42311-224 \ldots \ldots \ldots \ldots \ldots \ldots \ldots \ldots \ldots \ldots \ldots \ldots . \ldots \ldots \ldots$

5.8 Daily Use Pattern for Site $23211-558 \ldots \ldots \ldots \ldots \ldots \ldots \ldots \ldots \ldots \ldots \ldots \ldots \ldots . \ldots \ldots$

5.9 Daily Use Pattern for Site $42111-021$...................... 5.12

5.10 Daily Use Pattern for Site $41111-237$...................... 5.12

5.11 First Law Efficiency for Site $12111-117 \ldots \ldots \ldots \ldots \ldots \ldots \ldots \ldots \ldots \ldots \ldots$.......... $5 . \ldots$ 


\section{TABLES}

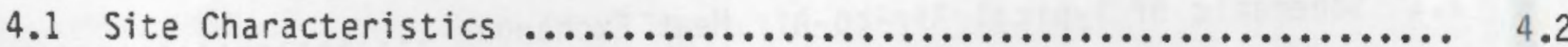

4.2 Site with Data for Utilization, Efficiency, and Energy Saving Calculations ...................................... 4.4

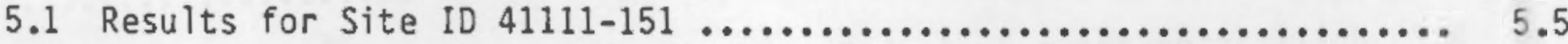

5.2 Therma1 Performance of Site ID $41111-151 \ldots \ldots \ldots \ldots \ldots \ldots \ldots \ldots \ldots . .6 .7$

5.3 Annual Performance of Air-to-Air Heat Exchanger Installations ...... 5.13

5.4 Mean Utilization of Air-to-Air Heat Exchangers by Climate Zone ..... 5.14

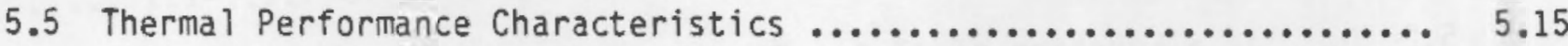

5.6 Mean First Law Efficiency of Air-to-Air Heat Exchangers

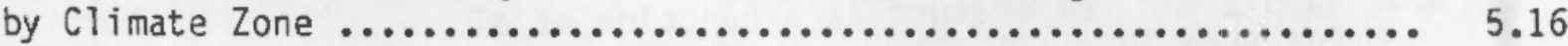

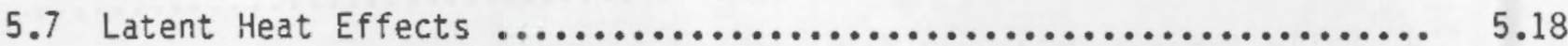

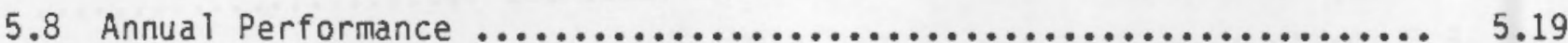




\subsection{INTRODUCTION}

This report documents the results of an evaluation of the performance of 38 residential air-to-air heat exchangers (AAHXs) installed in structures built as part of the Residential Standards Demonstrations Program (RSDP). The evaluation was conducted at the Pacific Northwest Laboratory (PNL).

\subsection{BACKGROUND}

The Bonneville Power Administration (BPA) initiated the RSDP in 1983 to determine the costs and thermal performance improvements associated with increased levels of thermal integrity in new residences as proposed by the Northwest Power Planning Council in their Model Conservation Standards (MCS). The program resulted in the construction of approximately 430 new residences built to thermal performance standards as dictated by the MCS in each of three climate zones in the Northwest. A subset of the residences has been included in the End-Use Load and Consumer Assessment Progran (ELCAP) being conducted at PNL. These structures are metered to record hourly energy consumption for several end uses.

Many of the structures built to MCS criteria include AAHXs to provide ventilation for maintenance of indoor air quality and comfort. Of the 71 MCS structures included in ELCAP, 38 include air-to-air heat exchangers and had sufficient data to allow an analysis of use patterns and thermal performance. This report describes the results of the analysis of the 38 AAHX installations using data collected as part of ELCAP.

\subsection{AIR-TO-AIR HEAT EXCHANGERS}

An AAHX is a device that provides ventilation with heat recovery. During periods requiring heating, indoor air (exhaust air) is exhausted from a structure and is used as a heat source to warm the cold incoming outdoor air (intake air). The AAHX is shown schematically in Figure 1.1. An AAHX system consists of the following components.

- Exhaust Air Ducting--This component collects exhaust air from vents throughout the structure and transports it to the AAHX. 


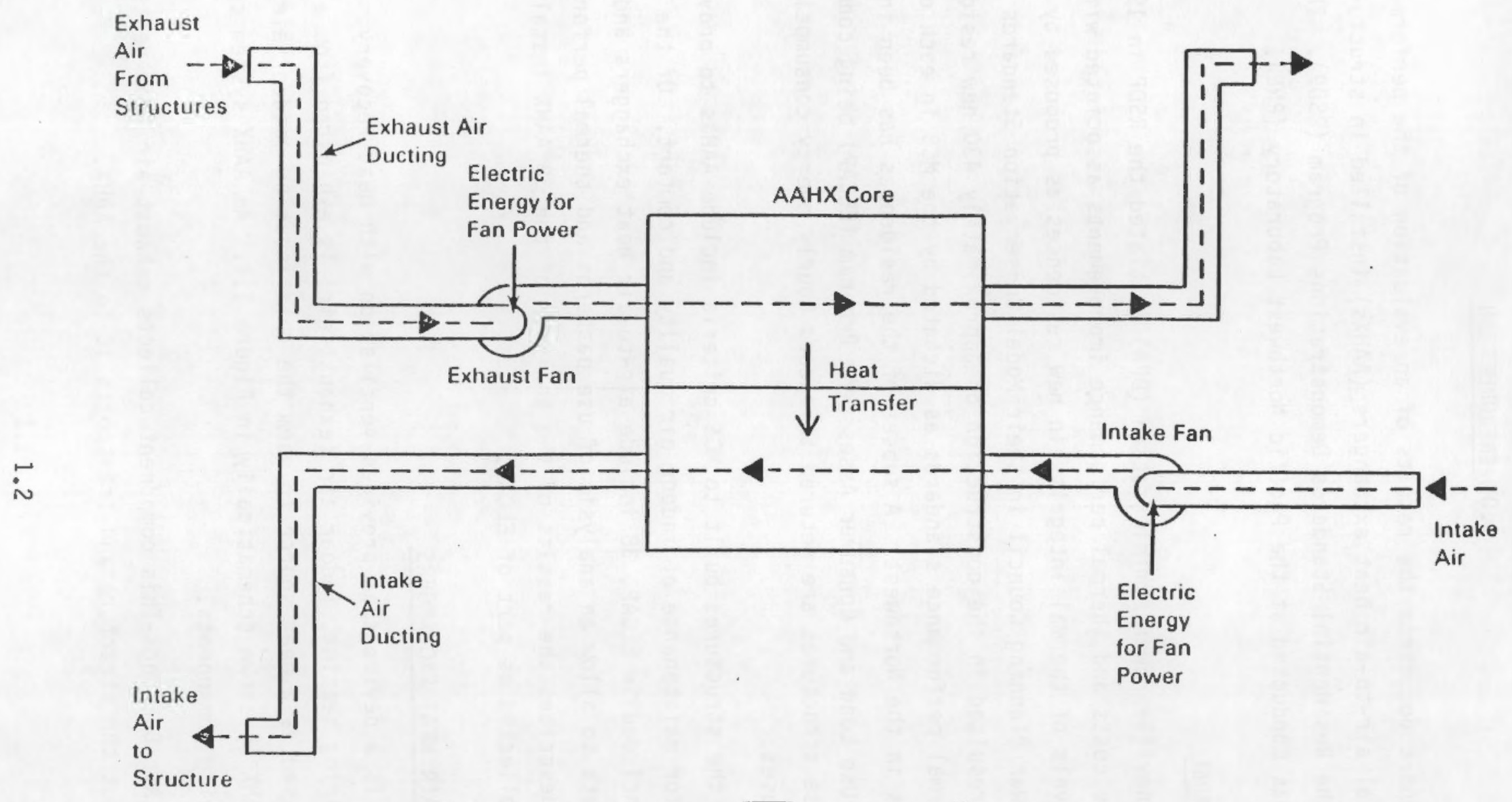

FIGURE 1.1. Schematic of a Typical Air-to-Air Heat Exchanger 
- Exhaust Air Fan-- The exhaust air fan draws exhaust air from the structure, forces the air through the AAHX core and exhaust ducting to the outside.

- AAHX Core--The AAHX core consists of the heat exchanger surfaces that actually transfer energy from the warm exhaust to cold intake air.

- Intake Air Ducting--This component transports intake air from the outside through ducting to vents throughout the structure.

- Intake Air Fan--The intake air fan draws air into the structure and blows it through the AAHX core and ducting to the intake air vents.

- Controls--The AAHX can be controlled manually or automatically. Automatic control normally measures indoor humidity and activates the AAHX system when the humidity exceeds a set point value.

The AAHX system can provide ventilation in an energy efficient manner but system cost effectiveness has not been demonstrated (Alexander 1985; Fisk and Turiel 1983). System cost effectiveness will depend on thermal performance and use patterns. This study investigates both use patterns and various measures of thermal performance. A more complete discussion of AAHX technology is presented in NCAT (1984), Schaub (1983), and Shurcliff (1982).

\subsection{ORGANIZATION OF REPORT}

There are five principal sections in this report. Section 2.0 describes the data available for analysis. Section 3.0 presents the analysis methodology. Section 4.0 discusses the characteristics of the sample available for analysis; Section 5.0 presents the results. Conclusions are presented and discussed in Section 6.0 . 
-

$x$

-

$-$ 


\subsection{AIR-TO-AIR HEAT EXCHANGER DATA}

The AAHX installations included in this study were instrumented to measure various air temperatures, fan power, and indoor humidity. Air flow rates were provided by the BPA.

\subsection{AIR-TO-AIR HEAT EXCHANGER ELCAP DATA}

The instrumentation for a typical AAHX installation is shown in Figure 2.1. Indoor air temperature is measured at two or three locations throughout the structure and averaged to obtain the indoor air temperature used in this study. The use of this value for the AAHX exhaust air inlet temperature implies that average structure air temperature is the same as the AAHX exhaust air inlet temperature. Intake air temperature is measured by a sensor located on the northern exterior of the structure. Exhaust air exit temperature is measured by a temperature sensor located in the exhaust air duct. Indoor humidity is measured in the structure and fan power consumption is measured at the circuit breaker. The temperature sensors have a measurement uncertainty of $\pm 1{ }^{\circ} \mathrm{C}$. The ELCAP data logger takes measurements 30 times per second, and hourly average values are recorded. Periodically the loggers are polled over phone lines and the data is transmitted to a central data storage and analysis center located at PNL.

\subsection{AIR FLOW DATA}

Air flow rates were not continuously monitored. Air flow rate data was taken from Reiland, Mckinstry, and Thor (1985). Reiland, McKinstry, and Thor report the results of a one-time measurement of intake and exhaust airflow during high speed operation. The details of the measurement procedure are also included in that report.

The relationship between the one-time air flow measurements, taken during high-speed operation, and the "as operated" air flows is not clear. To the 
Inside Air

Temperature

$\left(\mathrm{T}_{\mathrm{i}}\right)$

15

Inside

Humidity

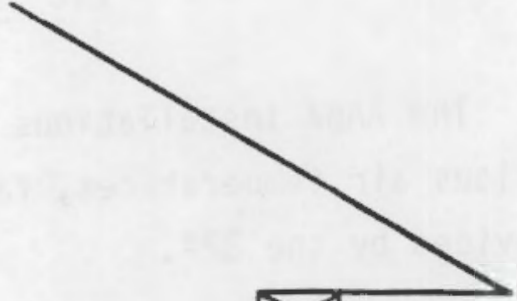

Inside

Structure
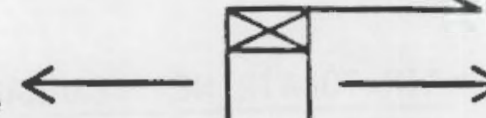

Outside

Structure

Outside

Air Temperature

$\left(T_{0}\right)$

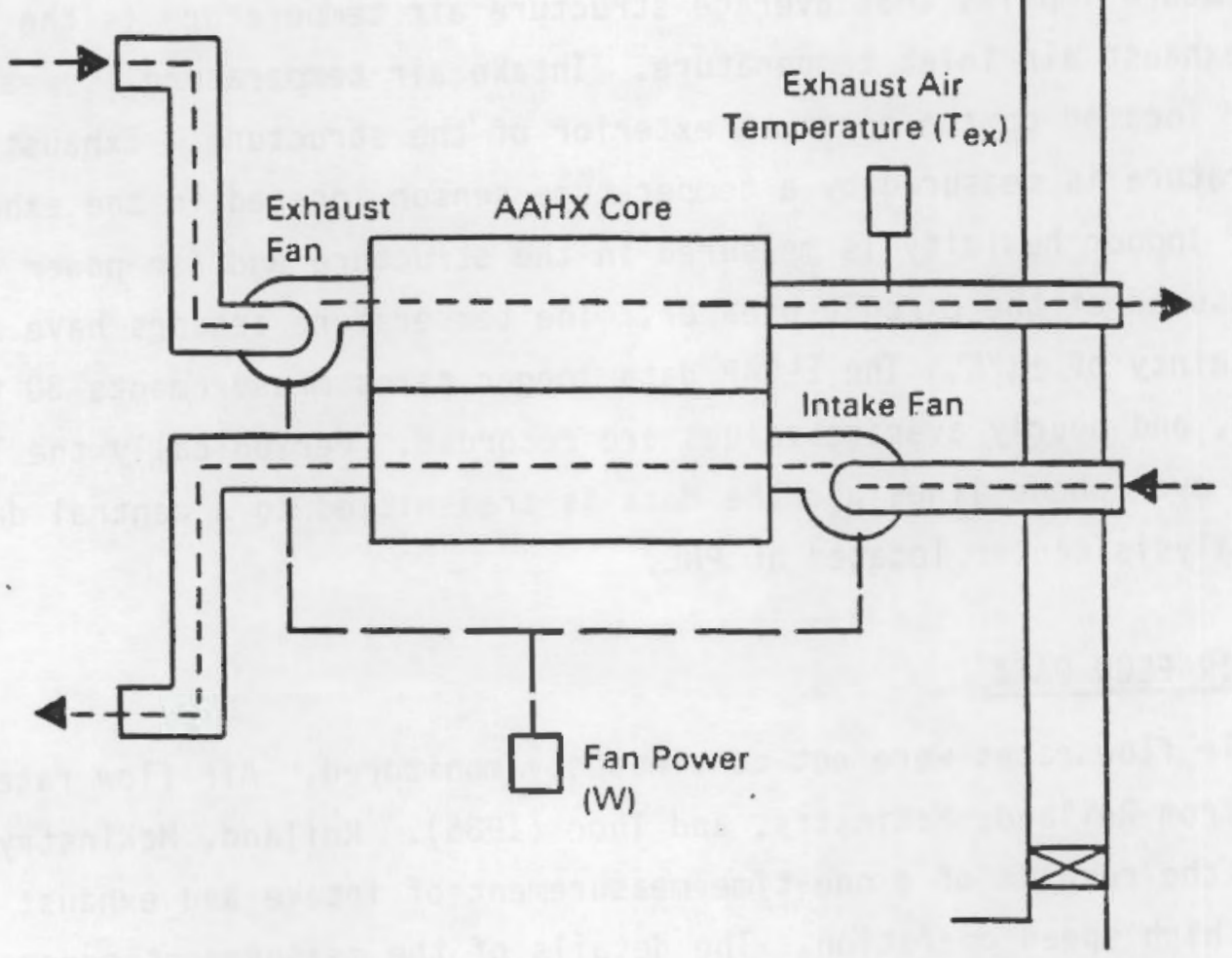

FIGURE 2.1. Typical Air-to-Air Heat Exchanger Instrumentation 
extent that "as operated" air flow deviates from the measured air flow, an error will be introduced into the calculation of space heating energy savings and the temperature of the intake air entering the structure. As discussed in Section 3, the calculation of first law efficiency does not depend on air flow data. 
. 


\subsection{METHOD OF ANALYSIS}

This section describes the objectives of the research followed by a discussion of the method used to analyze AAHX use patterns and AAHX thermal performance. The research had two objectives.

- AAHX Use Patterns--Currently, actual usage of AAHX installations is not well understood. The first objective of this study was to investigate and document the AAHX use patterns and, where possible, identify factors influencing AAHX use.

- Thermal Performance--The second objective of this study was to investigate and characterize the thermal performance of the AAHX installations included in this sample.

Section 3.1 discusses the investigation of use patterns, while Section 3.2 presents the method of analysis used in analyzing the thermal performance of the AAHX. Section 3.3 discusses assumptions and limitations associated with the analysis technique.

\subsection{AIR-TO-AIR HEAT EXCHANGER USE PATTERNS}

The AAHX use patterns were investigated by defining AAHX utilization, which is given as:

$$
\text { utilization }=\left(\begin{array}{c}
\text { actual AAHX power } \\
\text { consumption per time } \\
\text { period }
\end{array}\right)\left(\begin{array}{c}
\text { maximum AAHX power } \\
\text { consumption per time } \\
\text { period }
\end{array}\right)
$$

where maximum AAHX power consumption is the maximum fan power, exciuding electric energy used for freeze protection. A utilization of 1.0 would indicate that the AAHX was operated at full capacity for the complete time step. A utilization of 0.0 would indicate that the AAHX was not operated during the time period of interest. When the results of the utilization analys is are often reported as hours of operation per day, utilization, as defined by Equation (3.1), is multiplied by 24 . 
Maximum AAHX power was identified by sorting the hourly fan power data by magnitude. The largest frequently occurring hourly averaged AAHX energy consumption was selected as the maximum AAHX energy consumption. Occasionally several very high values of AAHX energy consumption occurred. These were interpreted as freeze protection loads and the next largest hourly AAHX energy consumption was used for the maximum. In most cases, maximum AAHX could be unambiguously identified.

With maximum AAHX energy consumption identified from hourly data, both hourly utilization and daily average utilization could be calculated. Figure 3.1 is an example of a plot of daily average utilization (reported as hours of operation during a day) for the 1986 heating season. Daily use patterns can be investigated by "folding" hourly data for a given period into a typical day. In this case, all available data for a given hour are combined to form a typical hour. As an example, assume that data are available for 30 days. The typical 10:00 hour would be calculated by examining the 30 readings for the

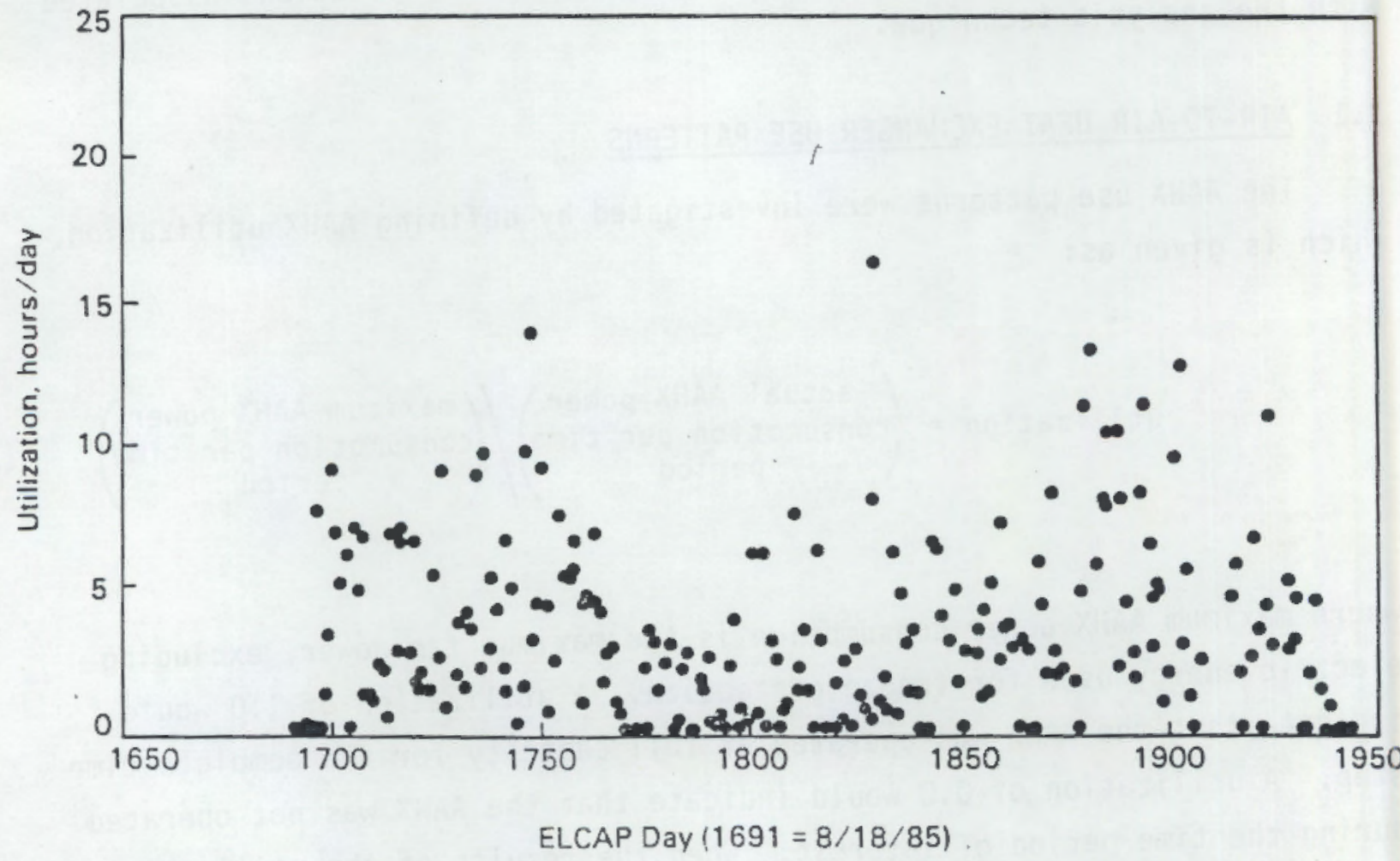

FIGURE 3.1. Daily Average Utilization for Site ID 41111-151 
10:00 hour from the 30 days of data. The median and quartiles are determined and reported for the 10:00 hour. This procedure is repeated for each hour of the day. The resulting day is typical of the 30 days being considered. Figure 3.2 presents hourly utilization for a typical day. Utilization is presented as "box plot" with one box plot for each hour. The characteristics of a box plot are described in Figure 3.3 (Becker and Chambers 1984).

\subsection{THERMAL PERFORMANCE CHARACTERISTICS}

The thermal performance of the AAHX installations was investigated using ELCAP data. First, the performance calculations only considered sensible heat transfer, then latent heat effects (condensation in the exhaust air flow) were estimated. Section 3.2.1 discusses the sensible heat transfer analysis procedure, Section 3.2.2 describes analysis of latent heat effects, and Section 3.2.3 presents a discussion of annual performance calculation methodology.

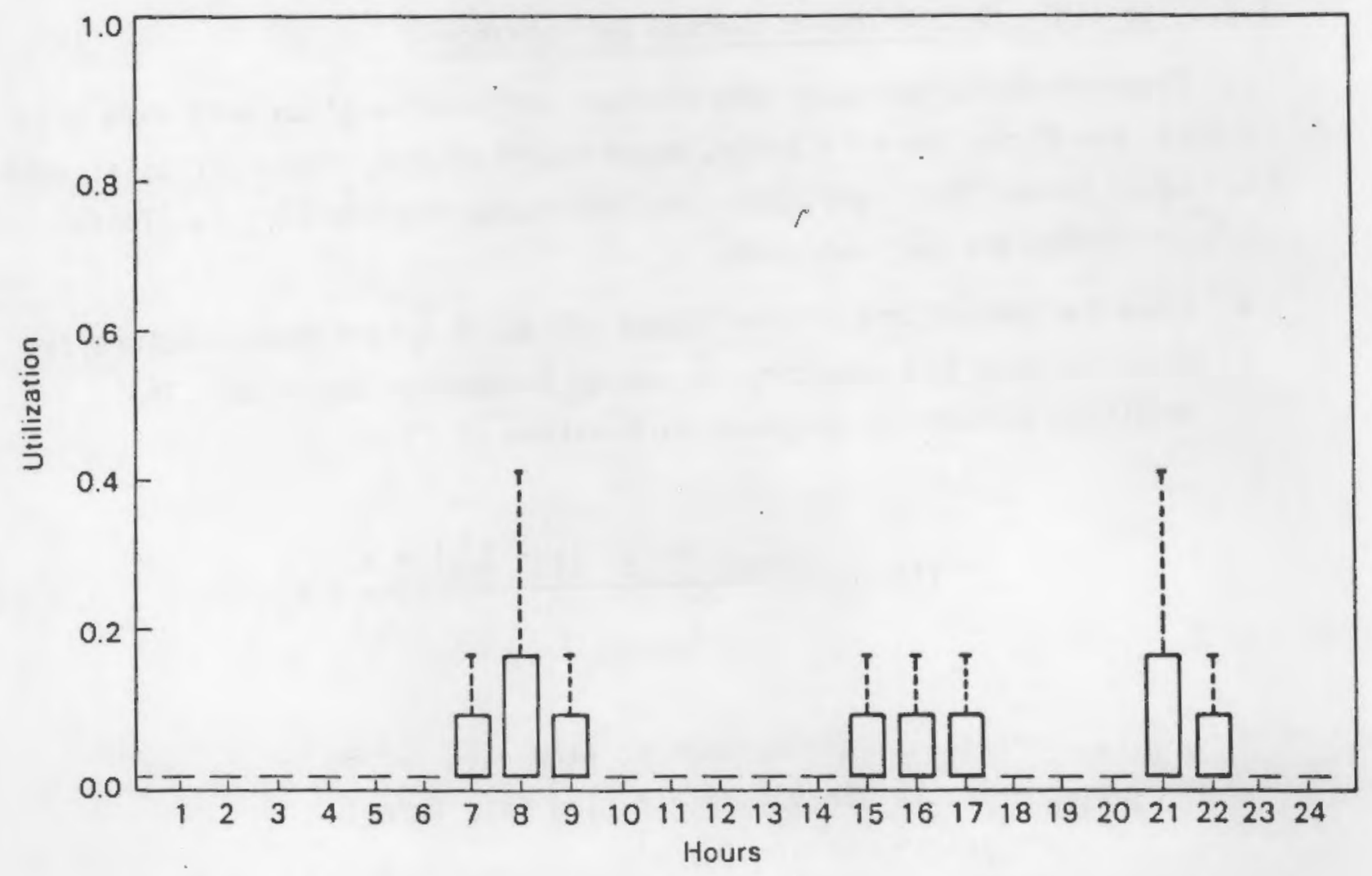

FIGURE 3.2. Utilization for a Typical Day for Site ID 41111-151 


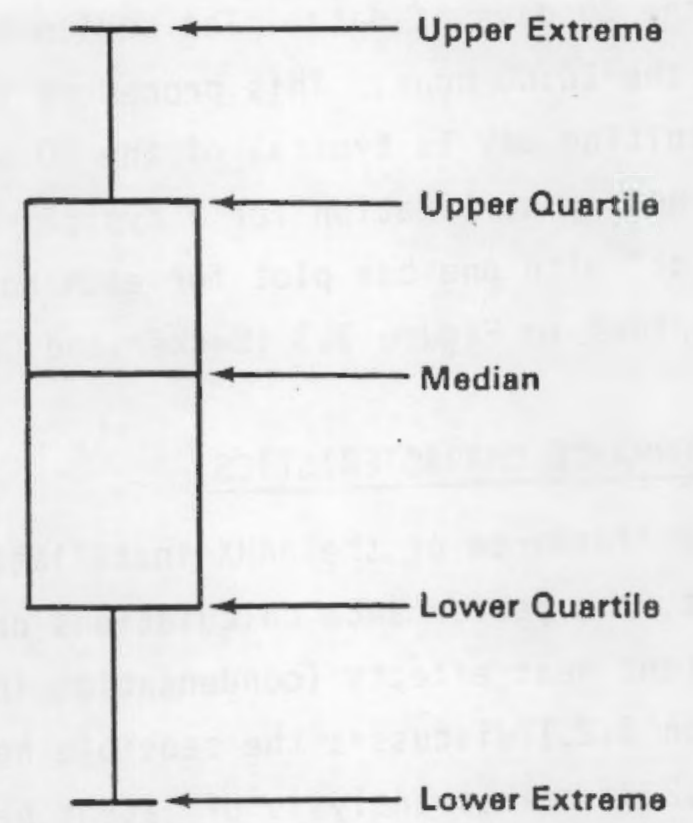

FIGURE 3.3. Characteristics of a Box Plot

\subsubsection{Sensible Heat Transfer Thermal Performance}

Three characteristics of the thermal performance of an AAHX were calculated; the first law efficiency, temperature of the intake air as it enters the living space (TIA), and space heating energy savings $\left(Q_{\text {sav }}\right)$. These characteristics are defined below.

- TIA--The temperature of the intake air as it enters the structure can be calculated by conducting an energy balance on the AAHX. The resulting expression is given by Equation (3.2).

$$
\text { TIA }=\frac{\dot{V}_{\text {exhaust }} \rho C_{p}\left(T_{i}-T_{\text {ex }}\right)+W}{\dot{V}_{\text {intake }} \rho C_{p}}+T_{0}
$$

$$
\text { where } \begin{aligned}
\dot{V}_{\text {exhaust }} & =\text { exhaust air volumetric flow rate }\left(\mathrm{m}^{3} / \mathrm{s}\right) \\
v_{\text {intake }} & =\text { intake air volumetric flow rate }\left(\mathrm{m}^{3} / \mathrm{s}\right) \\
\rho & =\text { density of air }\left(\mathrm{kg} / \mathrm{m}^{3}\right) \\
C_{p} & =\text { specific heat of air }\left(\mathrm{kJ} / \mathrm{kg}^{\circ} \mathrm{C}\right)
\end{aligned}
$$




$$
\begin{aligned}
T_{i} & =\text { inside air temperature }\left({ }^{\circ} \mathrm{C}\right) \\
T_{\text {ex }} & =\text { exhaust air temperature }\left({ }^{\circ} \mathrm{C}\right) \\
T_{0} & =\text { outside air temperature }\left({ }^{\circ} \mathrm{C}\right) \\
W & =\text { fan power }(\mathrm{kW}) .
\end{aligned}
$$

- First Law Efficiency--Several definitions of AAHX efficiency have been proposed (Alexander 1985). The most meaningful figure of merit is the first law efficiency. This figure of merit only includes the effects of heat transfer between air streams and does not include air steam temperature rises caused by viscous dissipation of fan work. The first law efficiency is given by Equation (3.3).

$$
\text { First Law Efficiency }=\frac{\left(T I A-T_{0}\right) \dot{V}_{\text {intake }} \rho C_{p}-W}{\left(T_{i}-T_{0}\right) \dot{V}_{\text {exhaust }} \rho C_{p}}
$$

The first law efficiency can be further simplified by substituting Equation (3.2) for TIA. The resulting expression is given in Equation (3.4).

$$
\text { First Law Efficiency }=\frac{\left(T_{i}-T_{\text {ex }}\right)}{\left(T_{i}-T_{0}\right)}
$$

This relationship elearly indicates that, while first law efficiency is a function of air flow, the actual calculation of first law efficiency does not require information on air flow.

- Q Qav--The space heating energy saved by the AAHX is calculated by determining the space heating energy that would be required to heat the incoming air to TIA. This is the energy savings that can be credited to the AAHX, assuming that the ventilation was required and would be supplied by some other means if the AAHX was not installed. 


$$
Q_{\text {sav }}=\dot{V}_{\text {fresh }} \rho C_{p}\left(T F R-T_{0}\right)
$$

Thermal performance characteristics are only meaningful for time periods when the AAHX is operating; therefore, some method of identifying AAHX operation was required. The selected method consisted of using hourly average data and calculating utilization for each hour. Utilization was then used to identify hours with substantial operation. Any hour with a utilization greater than 0.9 was identified as a high utilization period. The characteristics of thermal performance were then calculated for each hour with a utilization exceeding 0.9. Because operating patterns often resulted in many low utilization hours, it was not possible to obtain continuous time series data for performance characteristics. It is more appropriate to view the resulting characteristics of thermal performance as the results of a series of one hour performance tests on the AAHX.

Initial analysis of the performance data showed that either when the AAHX exhaust temperature $\left(T_{e x}\right)$ was close to the AAHX exhaust inlet temperature $\left(T_{j}\right)$ or when the outdoor temperature $\left(T_{0}\right)$ approached the AAHX exhaust air inlet temperature unrealistic results could be obtained. Due to the uncertainty in the temperature sensors, situations were encountered where first law efficiency exceeded 1.0, which is impossible for an adiabatic AAHX. To avoid this problem, two additional tests were performed on each high utilization hour. To be included in the thermal performance analysis, the data for a specific hour must meet the following tests:

$$
\begin{aligned}
& \text { utilization }>0.9 \\
& T_{i}-T_{e x}>2{ }^{\circ} \mathrm{C} \\
& T_{i}-T_{0}>5{ }^{\circ} \mathrm{C}
\end{aligned}
$$

These tests ensured that each analyzed hour for a given AAHX installation had high utilization and that the relevant temperature difference exceeded the uncertainty associated with the temperature sensors. 


\subsubsection{Latent Heat Effects}

The analysis described in Section 3.2.1 only considers sensible heat transfer, but under certain operating conditions latent heat effects can have a significant impact on AAHX performance. Exhaust air from inside the structure will include water vapor. As the exhaust air passes through the AAHX it will cool and the capacity of the air to carry water vapor will decrease. When the temperature reaches the saturation temperature, associated with the partial pressure of the water vapor, condensation will begin. As condensation continues heat will be released and transferred to the incoming intake air.

The analysis procedure consists of a series of calculations that are conducted on hourly data which has met the requirements of the three tests described in Section 3.2.1. These steps include the following.

- The water vapor pressure in the exhaust air stream at the inlet to the AAHX is calculated and compared to the saturation pressure based on AAHX exhaust air temperature (Van Wylen and Sonntag 1973). If the saturation pressure exceeds the vapor pressure then condensation has occurred during the hour currently being processed; consequently, latent heat effects may be significant.

- The relative humidity for AAHX exhaust stream inlet and outlet conditions is calculated for each hour demonstrating latent heat effects. The difference between the two relative humidity values can be used to determine the amount of condensed water vapor. An energy balance is then conducted on a control volume drawn around the exhaust side of the AAHX to determine the combined sensible and latent thermal energy transferred between the exhaust and intake air streams.

\subsubsection{Annual Performance Calculations}

The calculation of AAHX performance characteristics gave hourly results for hours with high utilization. Using hourly data, the indoor/outdoor temperature difference $(\Delta T)$ was plotted against TIA, first law efficiency, and $Q_{\text {sav }}$ with $\Delta T$ being the independent variable. A least-square linear fit was used to model the data. The resulting correlations can be used with information on $\Delta T$ 
to predict first law efficiency, Q $Q_{\text {Sav }}$, and TIA. Intuitively, $Q_{S a v}$ and TIA should be a function of $\Delta T$ but heat exchanger theory shows that first law efficiency should be independent of $\Delta T$. As the results presented in Chapter 5.0 will show, first law efficiency often shows a correlation with $\Delta T$.

Annual performance was determined by dividing the heating season (September 1, 1985 to April 27, 1986) into 17 two-week periods. For each period, the mean utilization, mean indoor/outdoor temperature difference, and mean AAHX energy consumption were determined. The mean utilization and indoor/outdoor temperature differences were used with the $Q_{\text {Sav }}$ correlation to determine the total reduction in space-heating energy consumption for the two-week period attributable to the AAHX. The mean AAHX energy consumption was used to calculate the total electric energy consumption of the AAHX for the two-week period. With this information available, the annual reduction in space-heating energy consumption, the annual AAHX energy consumption and the ratio of these two quantities was determined for all sites with sufficient data.

\subsection{ISSUES AFFECTING ANALYSIS TECHNIQUE}

The analysis method described in this report depends on assumptions and procedures that have the potential to bias the results. Key issues affecting the accuracy of the analysis procedure include:

- Identification of Maximum AAHX Energy Consumption--In most cases it was possible to unambiguously identify the maximum AAHX energy consumption but in several cases there was some uncertainty. One site was not included in the analysis because of difficulty in identifying maximum AAHX energy consumption.

- Air Flow Data--The determination of TIA and $Q_{s a v}$ depends on knowing exhaust and intake air flows. Air flow rates are taken from Reiland, McKinstry, and Thor (1985) and are the results of a one-time measurement of intake and exhaust air flow during high-speed operation. To the extent that measured air flow rates do not represent actual air flows, the calculations of TIA and Q Q will be affected. 
- AAHX Temperatures--The temperature used for AAHX exhaust inlet temperature is the average of two or three sensors measuring indoor air temperature. In this study, AAHX exhaust inlet temperature was assumed to equal the average indoor air temperature. In a similar manner, the AAHX intake air temperature was assumed to equal the outside air temperature. It is not clear that the AAHX inlet temperatures are accurately modeled by using the average indoor air temperature and outdoor air temperature as the AAHX inlet temperatures.

- Leakage--Leakage across the core was assumed to be negligible. Transport of energy in the core was assumed to consist solely of heat transfer without significant mass transfer. 


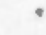




\subsection{SITE CHARACTERISTICS AND ANALYSIS}

Sufficient data have been obtained on 38 AAHX installations to allow the analysis of use patterns. Of these, 25 had sufficient data for determining the first law efficiency and 22 had sufficient data for calculating other measures of thermal performance. This section presents characteristics of the various sites and identifies the sites available for each level of analysis. A more complete discussion of overall site characteristics is presented in Drost et al. (a)

\subsection{SITE CHARACTERISTICS}

Table 4.1 presents selected characteristics of the AAHX installations. The first column is the RSDP site identification number. The significance of the site identification number is explained in Appendix B. The second column indicates the climate zone in which the structure containing the AAHX is located. A climate zone is a geographical region with similar meteorology. Climate zone one includes Oregon and Washington west of the Cascade Mountains. Climate zone two includes eastern Oregon and Washington and much of Idaho; climate zone three includes the Rocky Mountain region. Figure 4.1 shows the three climate zones. Column three presents the heated floor area of the structure containing the AAHX. The fourth and fifth columns present the inlet and outlet air flows respectively, while the sixth column gives the maximum AAHX fan energy use. The "comments" section includes comments on the site. Normally these indicate some shortcoming in the available data.

\subsection{SITES AVAILABLE FOR ANALYSIS}

Sites can be in one of three categories. If data on fan power consumption are available then the utilization can be calculated and analyzed for the site. If, in addition to fan power, temperature data from all temperature sensors and humidity are available, then the first law efficiency and latent heat effects can be calculated. Finally, if air flow rates are available in

(a) Analysis of Thermal Performance Data Taken Under the Residential Standards 


\section{TABLE 4.1. Site Characteristics}

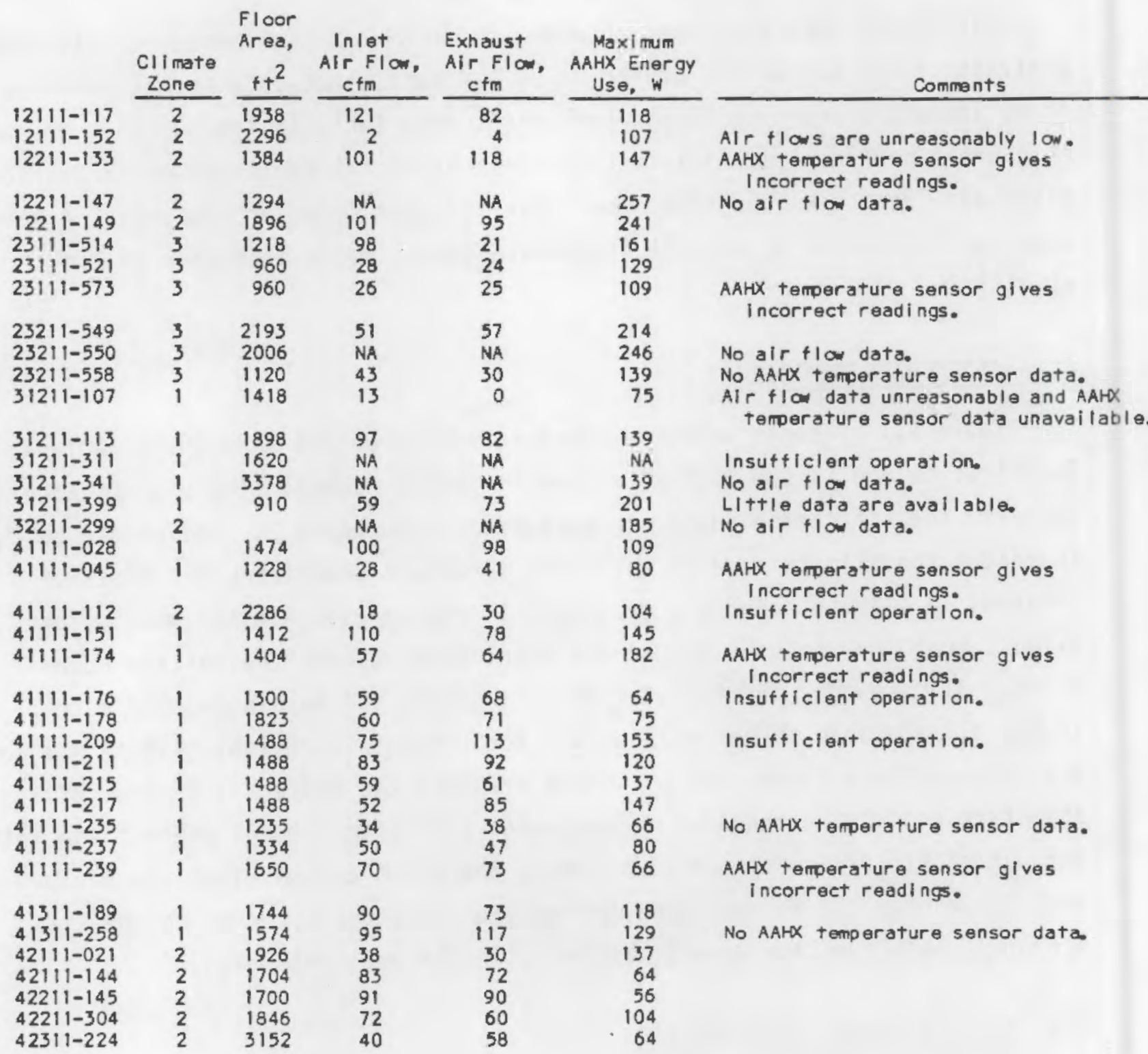

addition to temperature data and fan power, then the savings in space heating energy consumption, and incoming air temperature can be determined. Table 4.2 indicates which sites were available for each level of analysis. 


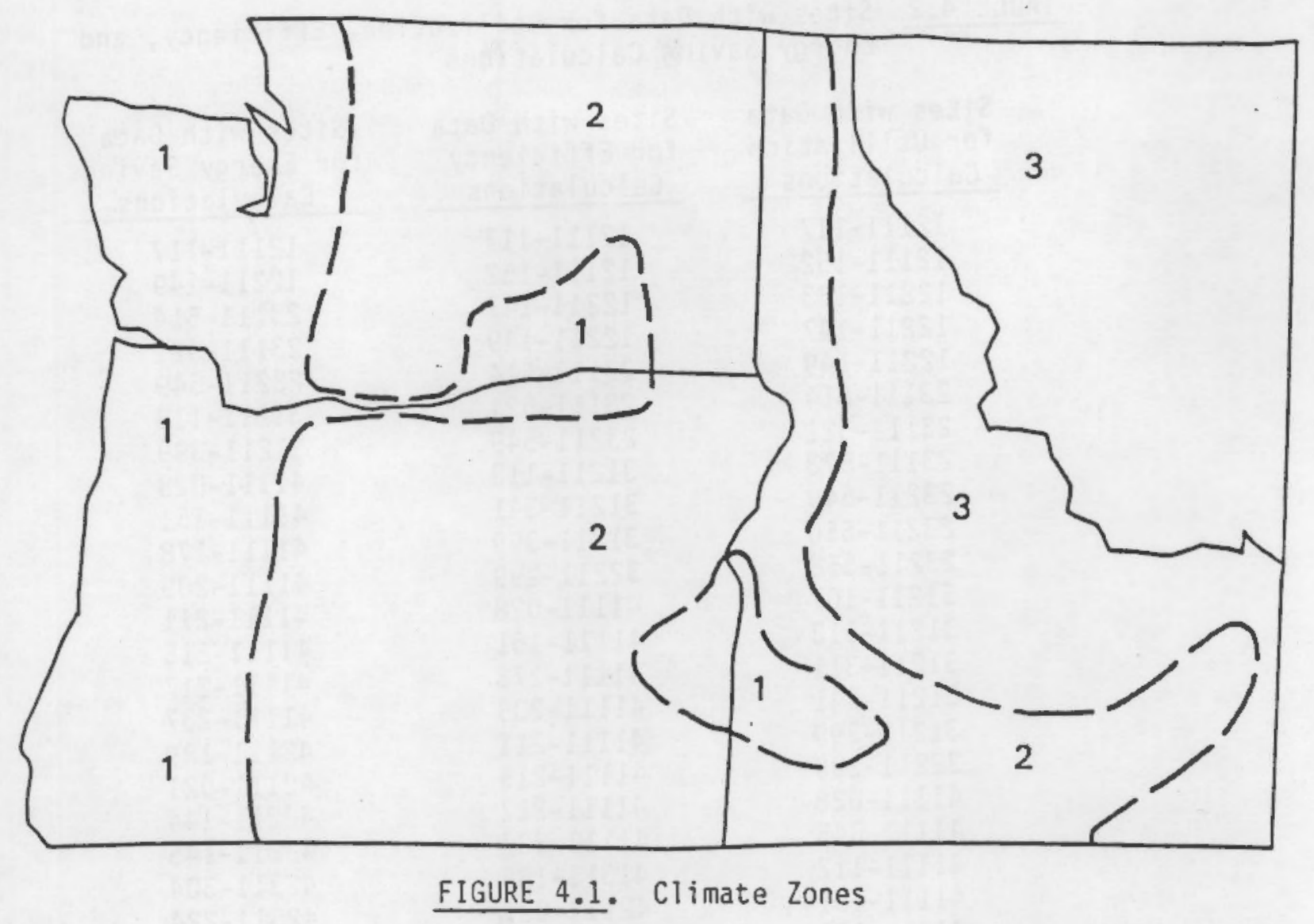


TABLE 4.2 Sites with Data for Utilization, Efficiency, and Energy Saving Calculations

\begin{tabular}{|c|c|c|}
\hline $\begin{array}{l}\text { Sites with Data } \\
\text { for Utilization } \\
\text { Calculations } \\
\end{array}$ & $\begin{array}{l}\text { Sites with Data } \\
\text { for Efficiency } \\
\text { Calculations } \\
\end{array}$ & $\begin{array}{l}\text { Sites with Data } \\
\text { for Energy Savings } \\
\text { Calculations } \\
\end{array}$ \\
\hline $\begin{array}{l}12111-117 \\
12111-152 \\
12211-133 \\
12211-147 \\
12211-149 \\
23111-514 \\
23111-521 \\
23111-573 \\
23211-549 \\
23211-550 \\
23211-558 \\
31211-107 \\
31211-113 \\
31211-311 \\
31211-341 \\
31211-399 \\
32211-299 \\
41111-028 \\
41111-045 \\
41111-112 \\
41111-151 \\
41111-174 \\
41111-176 \\
41111-178 \\
41111-209 \\
41111-211 \\
41111-215 \\
41111-217 \\
41111-235 \\
41111-237 \\
41111-239 \\
41311-189 \\
41311-258 \\
42111-021 \\
42111-144 \\
42211-145 \\
42211-304 \\
42311-244\end{array}$ & $\begin{array}{l}12111-117 \\
12111-152 \\
12211-147 \\
12211-149 \\
23111-514 \\
23111-521 \\
23211-549 \\
31211-113 \\
31211-341 \\
31211-399 \\
32211-299 \\
41111-028 \\
41111-151 \\
41111-178 \\
41111-209 \\
41111-211 \\
41111-215 \\
41111-217 \\
41111-237 \\
41311-189 \\
42111-021 \\
42111-144 \\
42211-145 \\
42211-304 \\
42311-224\end{array}$ & $\begin{array}{l}12111-117 \\
12211-149 \\
23111-514 \\
23111-521 \\
23211-549 \\
31211-113 \\
31211-399 \\
41111-028 \\
41111-151 \\
41111-178 \\
41111-209 \\
41111-211 \\
41111-215 \\
41111-217 \\
41111-237 \\
42111-189 \\
42111-021 \\
42211-144 \\
42211-145 \\
42311-304 \\
42311-224\end{array}$ \\
\hline
\end{tabular}




\subsection{RESULTS OF THE AIR-TO-AIR HEAT EXCHANGER EVALUATION}

This section presents the results of the AAHX evaluation. Section 5.1 discusses typical results for one installation. Section 5.2 presents the results of the use pattern investigation while Section 5.3 describes the sensible heat transfer thermal performance characteristics. Latent heat effects are discussed in Section 5.4 and the results of the annual performance calculations are presented in Section 5.5 .

\subsection{SAMPLE RESULTS}

Each AAHX installation was investigated in a variety of ways. This section will describe the results of each investigation for one site, ID 41111-151, while the following sections present the results for the completed sample.

\subsubsection{Use Patterns}

The results of the analysis of use patterns for site ID 41111-151 are presented in two ways. Figure 3.1 shows daily average utilization (in hours of operation per day) for the 1986 heating season, where the heating season is defined as the time period between August 18, 1985 and April 28, 1986. Figure 3.2 presents utilization for a typical day. In this case the typical utilization for each hour is reported in a box plot.

\subsubsection{Sensible Heat Thermal Performance}

The three measures of thermal performance, TIA, first law efficiency, and $Q_{\text {sav }}$, were calculated for each hour with high utilization. The results were then modeled by determining a linear fit to the data plotted as a function of indoor-outdoor temperature difference ( $\Delta T$ ). The results for site ID 41111-151 are presented on three figures: Figure 5.1 shows the first law efficiency as a function of $\Delta T$, Figure 5.2 plots $Q_{S a v}$ as a function of $\Delta T$, and Figure 5.3 presents the temperature of the intake air as it enters the structure as a function of $\Delta T$. The thermal performance can be summarized by four results: mean first law efficiency and the three linear fits. The linear fits were determined for $\Delta T$ in ${ }^{\circ} \mathrm{C}$. Table 5.1 presents the results for site ID 41111-151. 


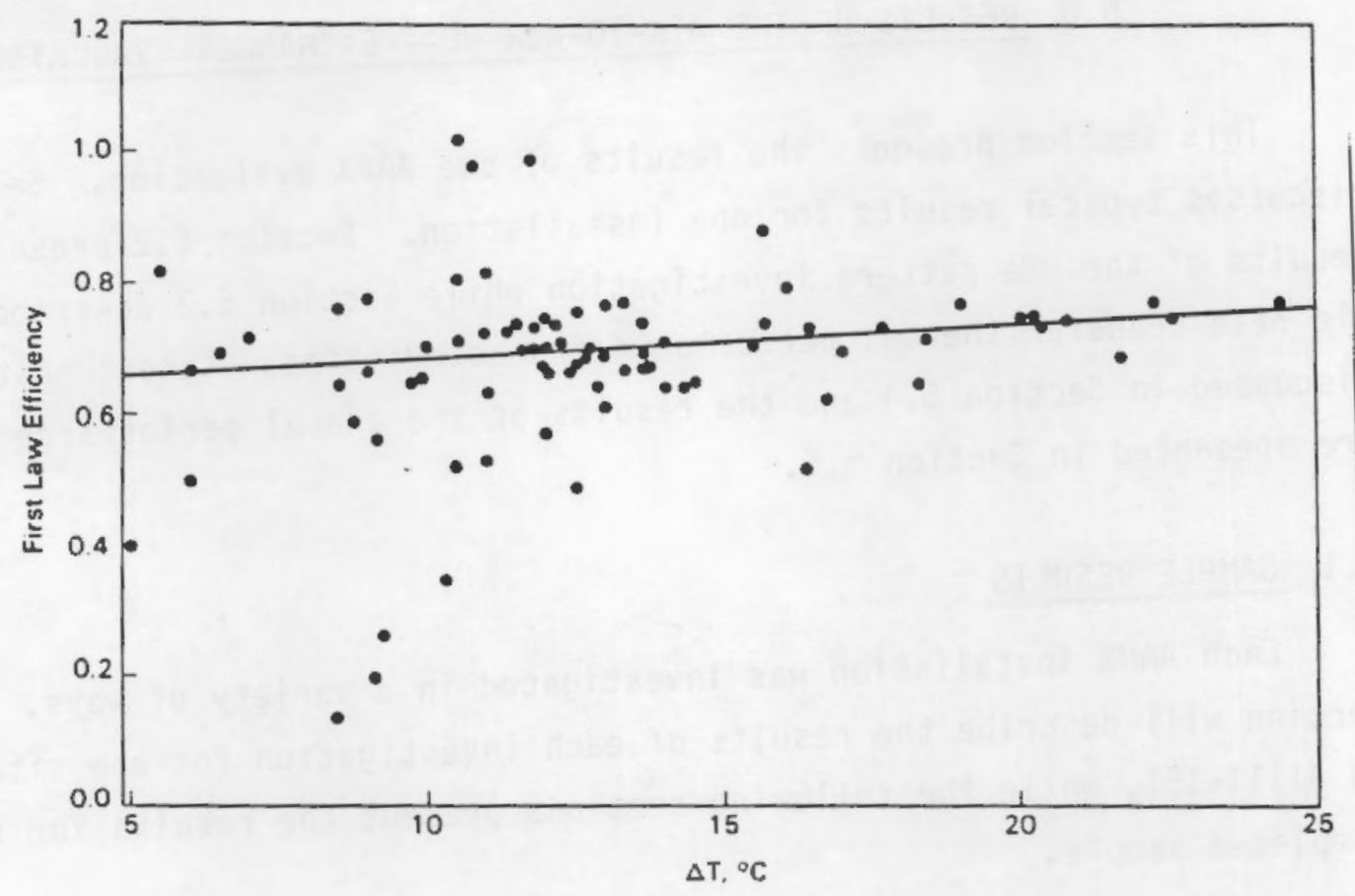

FIGURE 5.1. Daily Average Utilization for 41111-151

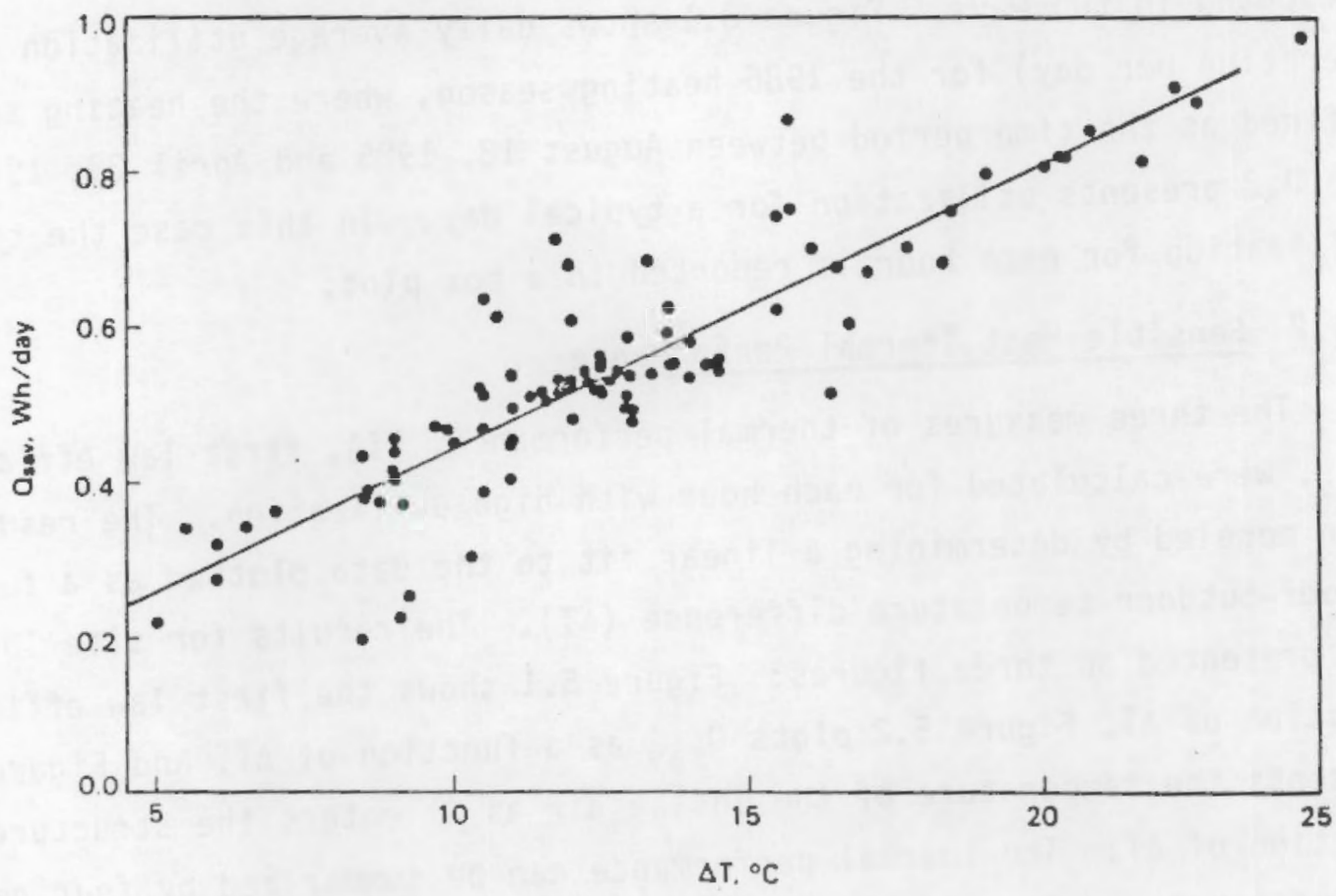

FIGURE 5.2. Utilization for a Typical Day for 41111-151. 


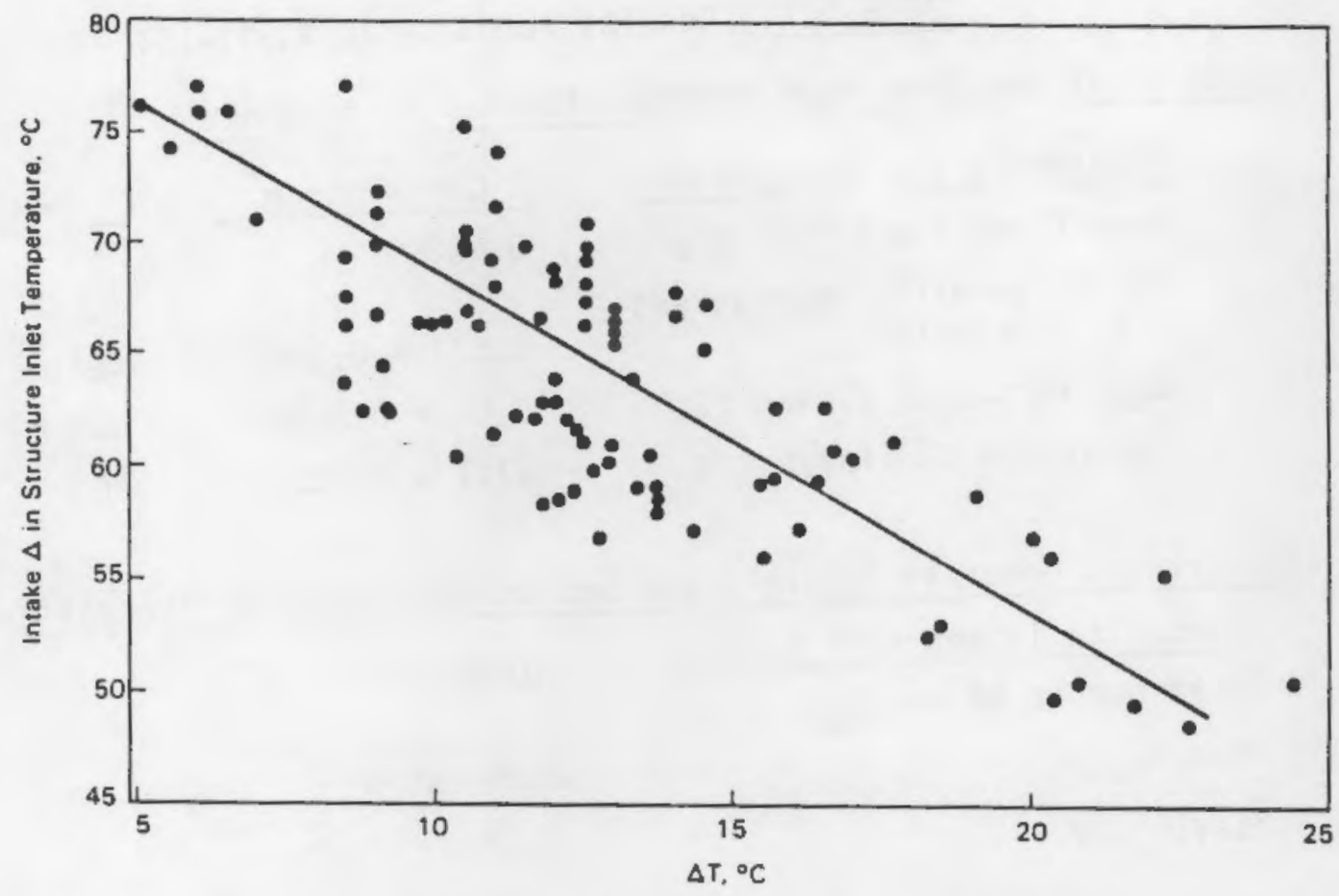

FIGURE 5.3. 1st Law Efficiency Versus $\Delta T$ for 41111-151

\subsubsection{Latent Heat Performance}

Each high utilization hour was checked for latent heat effects. If condensation was occurring then the reduction in space heating energy consumption caused by the AAHX, including both sensible and latent heat transfer $\left(Q_{\text {Savl }}\right)$, was calculated for that hour. The potential impact of latent effects was indicated by three results. The first significant result was the number of high utilization hours with exhaust stream condensation. This indicated the frequency of condensation. The second result was $Q_{s a v l}$, which is the displaced space heating energy consumption including both latent and sensible heat transfer. Finaliy, the ratio of $Q_{s a v l}$ to $Q_{\text {sav }}$ for hours with exhaust stream condensation was calculated. This indicates the importance of latent heat effects when they occur. Table 5.1 presents these measures of thermal performance.

\subsubsection{Annual Performance}

Annual performance of site ID 41111-151 for 17 two-week periods is reported in Table 5.2. For each period, the mean utilization, mean $\Delta T$, and 
TABLE 5.1. Results for Site ID 41111-151

Measures of Sensible Heat Transfer Thermal Performance

\begin{tabular}{|c|c|c|}
\hline Peformance characteristics & Correlation & Units \\
\hline Mean first law efficiency & 0.683 & \\
\hline $\begin{array}{l}\text { First law efficiency versus } \\
\Delta T \text { linear fit }\end{array}$ & $0.573+0.008 \Delta T$ & decimal \% \\
\hline$Q_{\text {Sav }}$ versus $\Delta T$ linear fit & $0.86+0.360 \Delta T$ & $\mathrm{kWh} / \mathrm{h}$ \\
\hline TIA versus $\Delta T$ linear fit & $27.1-0.731 \Delta T$ & ${ }^{\circ} \mathrm{C}$ \\
\hline
\end{tabular}

Measures of Combined Sensible and Latent Heat Transfer Thermal Performance hours with latent heat effects $20 / 98$

Total number of hours

$\begin{array}{ll}\text { Mean } Q_{\text {Savi }} & 0.89 \mathrm{kWh} / \mathrm{d} \\ \mathrm{Q}_{\text {Savl }} / \mathrm{Q}_{\text {Sav }} & 1.19\end{array}$

Annual Performance

\begin{tabular}{|c|c|c|}
\hline Mean utilization & 3.3 & $h / d$ \\
\hline Mean $\Delta T$ & 26.1 & ${ }^{\circ} \mathrm{F}$ \\
\hline $\begin{array}{l}\text { Mean } Q_{\text {sav }} \text { (sensible } \\
\text { heat transfer only) }\end{array}$ & 455 & $\mathrm{kWh} / \mathrm{d}$ \\
\hline Mean AHE & 113 & $\mathrm{kWh} / \mathrm{d}$ \\
\hline Mean ( $\mathrm{Q}_{\text {sav }} /$ AHE $)$ & 4.2 & \\
\hline
\end{tabular}

mean AAHX energy consumption (AHE) are reported. The $Q_{\text {sav }}$ versus $\Delta T$ correlation was used to calculate the mean $Q_{\text {sav }}$. The ratio of $Q_{S a v}$ to mean AHE is also reported. This last result can be viewed as a coefficient of performance for the device. The annual mean utilization, $\Delta T$ and $Q_{S a v} / A H E$ are reported in addition to the total annual $Q_{\text {sav }}$ and AHE. If a site is missing more than 3 weeks of data then total $Q_{S a v}$ and AHE are not calculated. For sites with 1 to 3 missing weeks of data the totals are calculated by taking the mean value for the available weeks and multiplying by 17 . 
TABLE 5.2. Thermal Performance of Site ID 41111-151

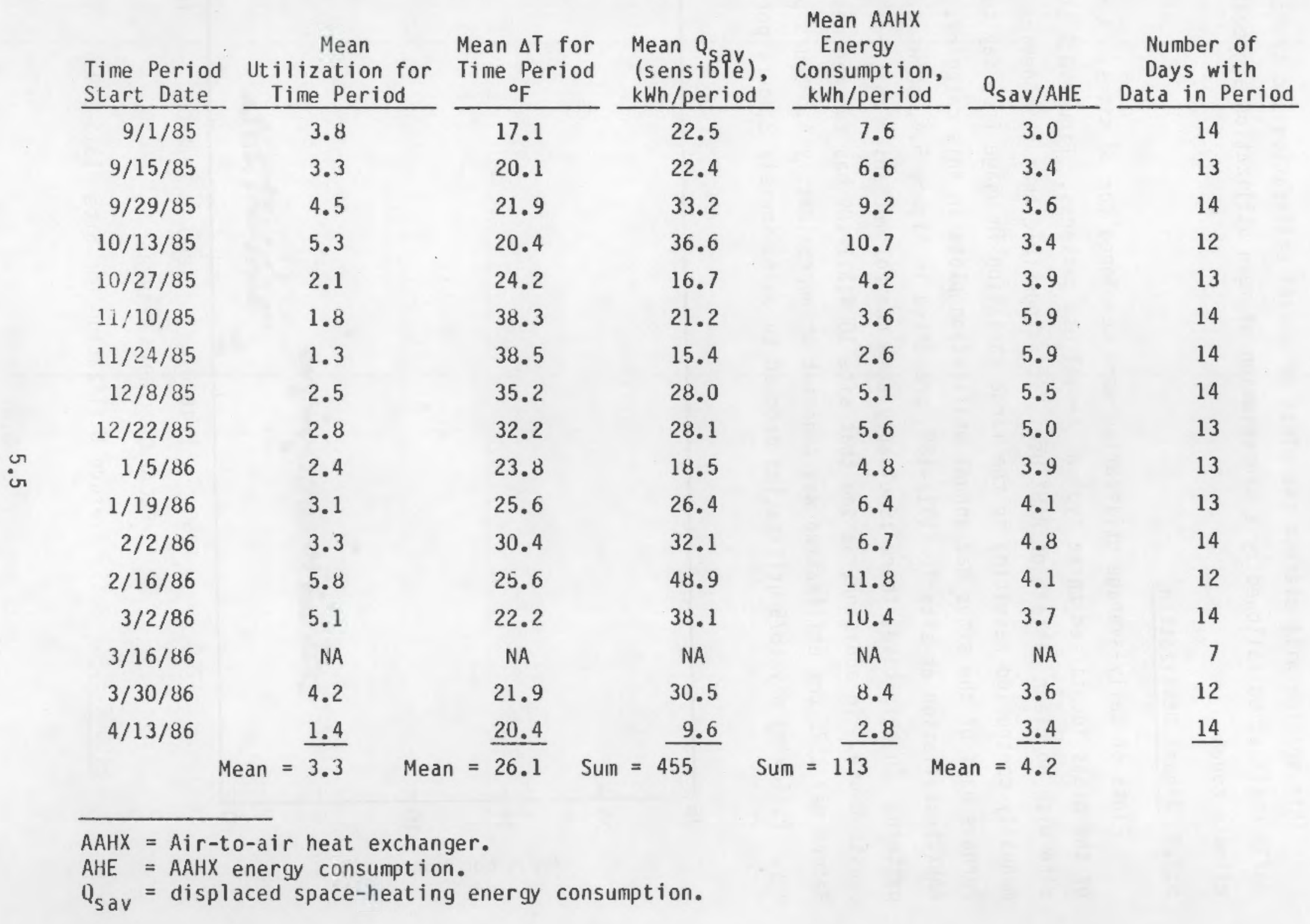




\subsection{UTILIZATION OF AIR-TO-AIR HEAT EXCHANGER UNITS}

This section will discuss the plots of annual utilization and typical daily utilization followed by a presentation of mean utilization aggregated by climate zone.

\subsubsection{Annual Utilization}

Plots of daily average utilization were developed for 38 sites. A review of the plots identified three typical annual use patterns. Figure 3.1 shows a site with no clear pattern of AAHX use. It is possible that this device is manually controlled resulting in the large variation in usage from day to day. Perhaps half of the sites had annual utilization plots in this category. The AAHX installation at site ID 41311-189, presented in Figure 5.4, shows a second pattern. In this case, there is clearly some control mechanism that results in constant use. In addition, we see that site ID 41311-189 has two regions. Before day 1875 the utilization was constant at approximately 4.5 hours per day. Following day 1875 utilization dropped to approximately 2 hours per day.

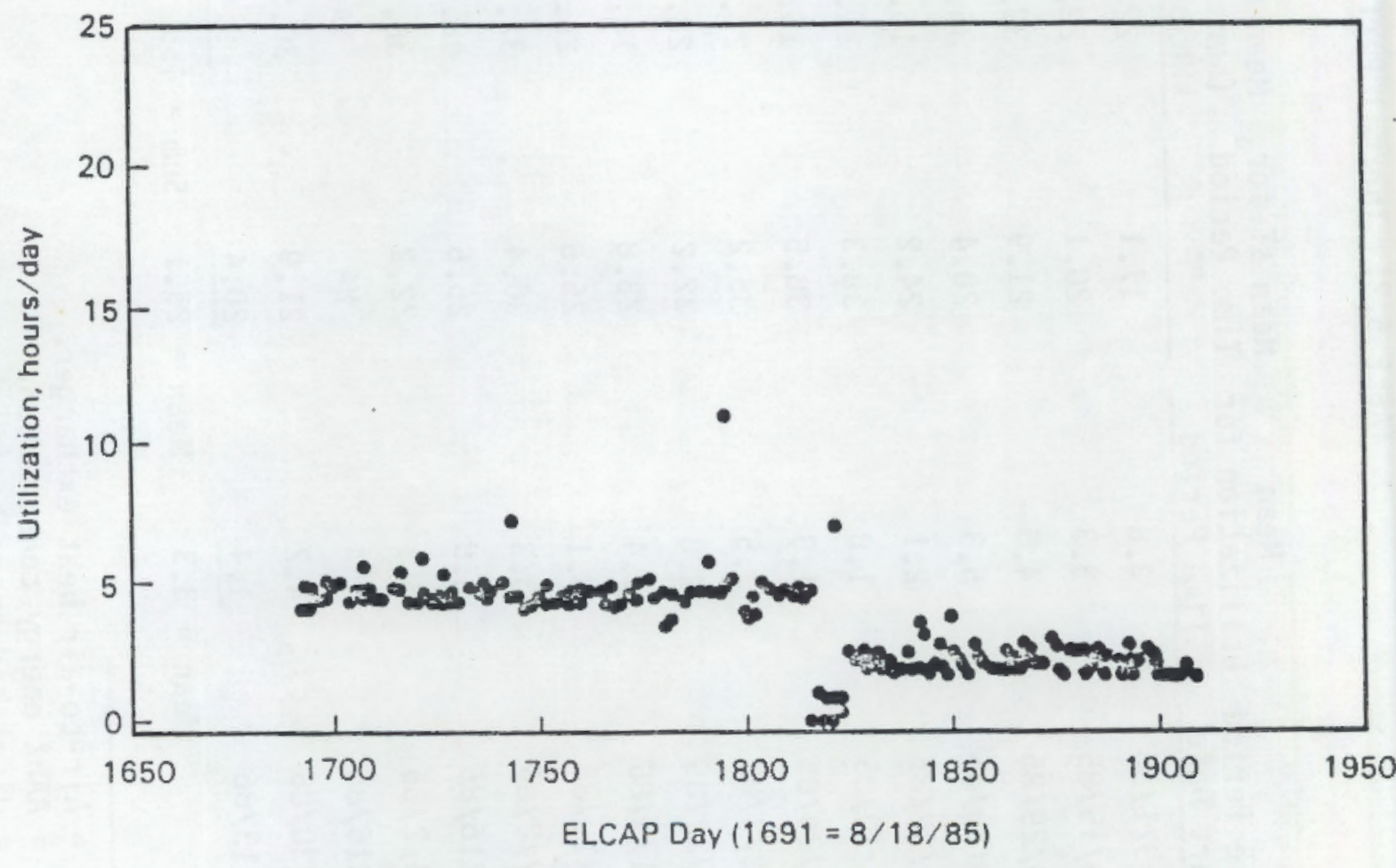

FIGURE 5.4. Daily Average Utilization for Site 41311-189 
Around $20 \%$ of the sites had substantial time periods with constant utilization. Site ID 41111-217, shown in Figure 5.5, is typical of the third use pattern. In these structures the AAHX was rarely used. This suggests that the device was normally not operated but that occasionally something would induce the operator to turn on the device. Five sites showed this behavior. Site ID 11211-136, shown in Figure 5.6, is the only site that demonstrates a clear seasonal trend, with utilization dropping during colder time periods. A visual inspection of the 38 sites did not indicate a widespread seasonally correlated variation in utilization.

\subsubsection{Typical Daily Use Patterns}

Plots of typical daily use patterns were developed for 38 AAHX installations. Of these, 13 lacked sufficient data to form a meaningful plot. In general, the daily use patterns do not show any dominant trends across the 25 installations. Eight of the AAHX installations show essentially constant utilization for all hours of a typical day. Site ID 42311-224, shown in

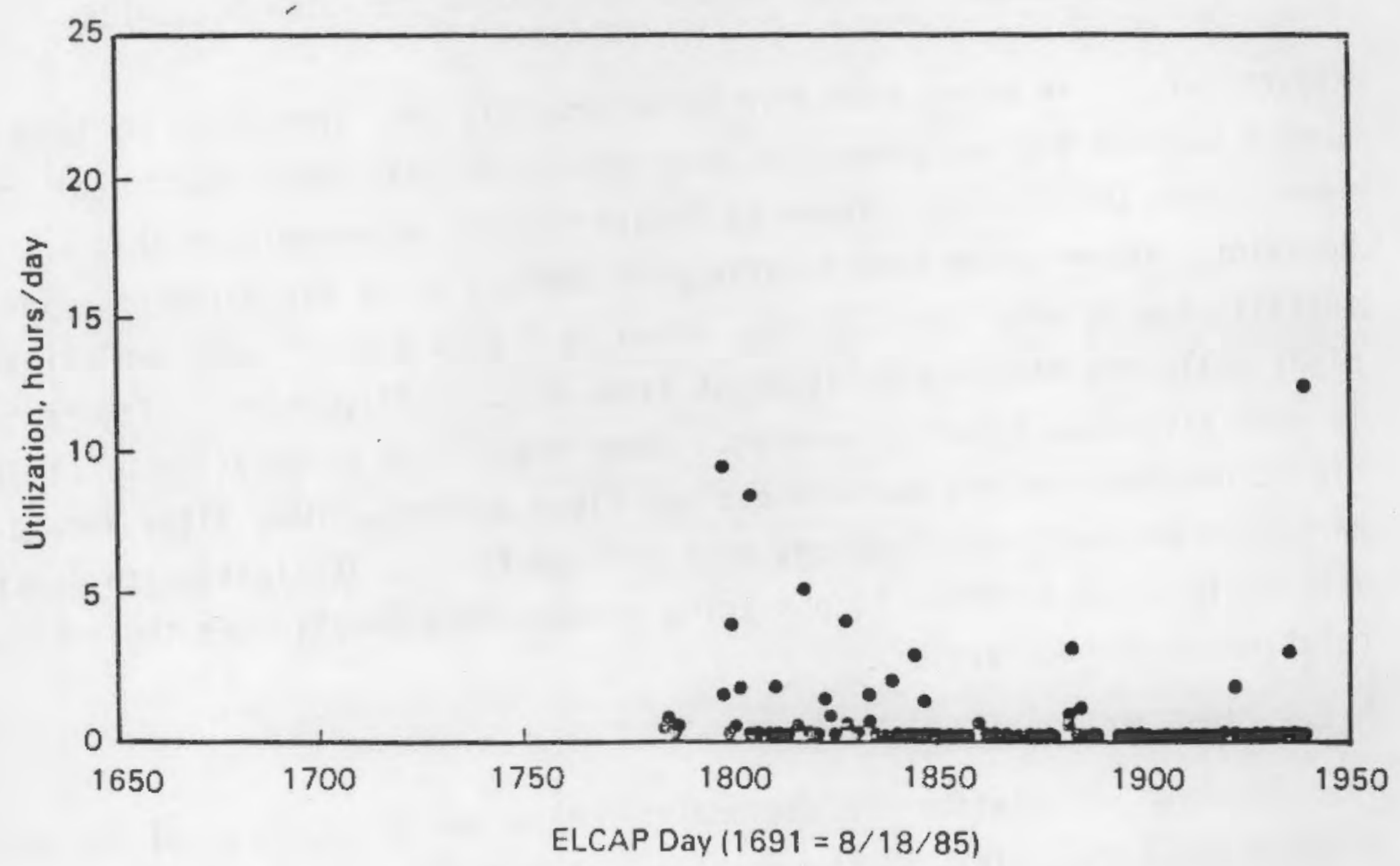

FIGURE 5.5. Daily Average Utilization for Site 41111-217 


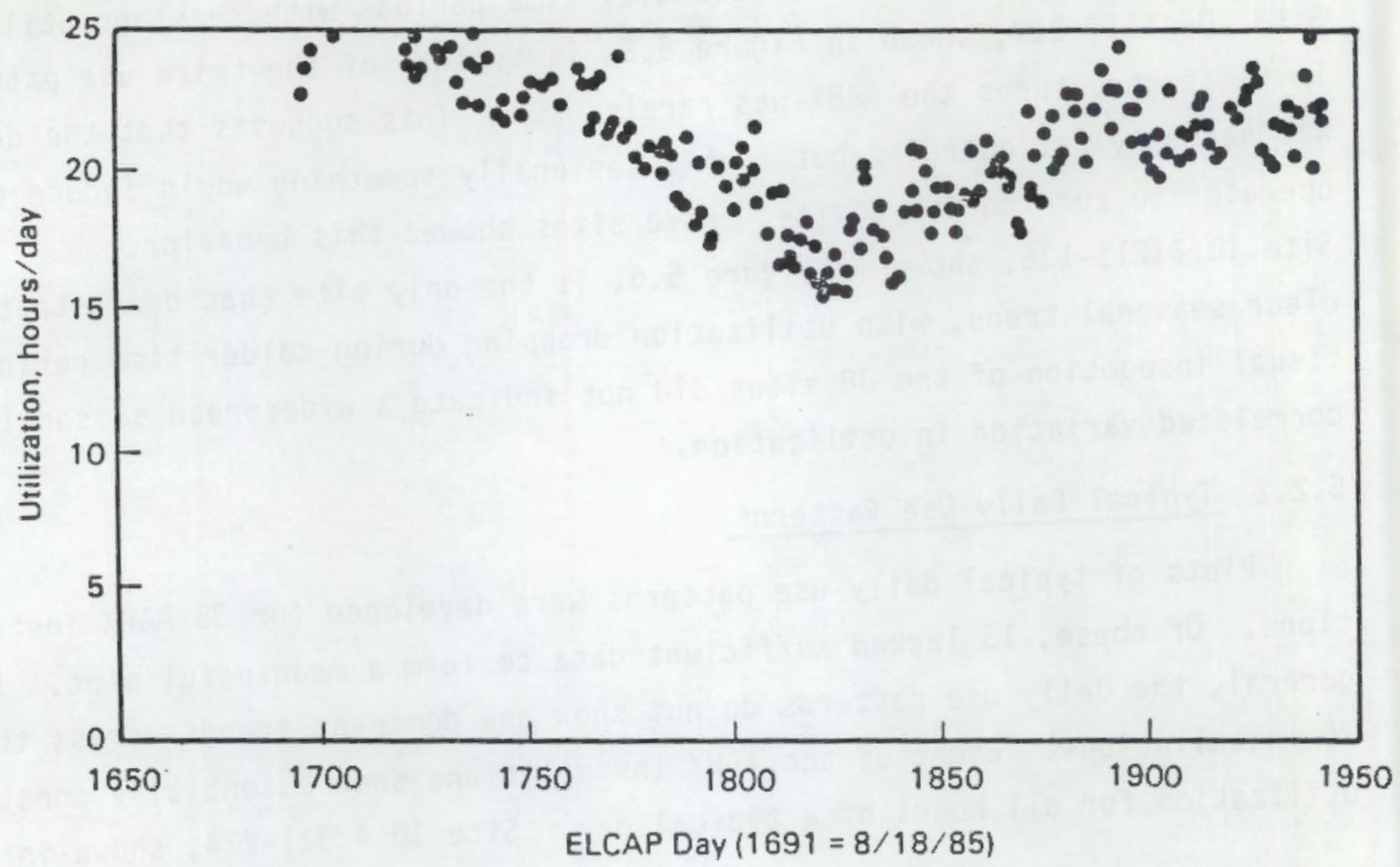

FIGURE 5.6. Daily Average Utilization for Site 11211-136

Figure 5.7, is an example of this behavior. Six AAHX installations seem to show a morning and early evening peak typical of many other electrical end uses. Site ID 23211-558, shown in Figure 5.8, is an example of this behavior. Other sites show a variety of typical daily use patterns. The AAHX installation at site ID 42111-021, shown in Figure 5.9, is used exclusively at night while the AAHX installation at site ID 41111-237, shown in Figure 5.10, is used exclusively in the morning. Other sites show a variation of utilization throughout the day but without any clear pattern. Many sites show a large variation in hourly utilization, with a range from no utilization to continuous utilization. In addition to obscuring trends, this complicates the interpretation of the box plot.

\subsubsection{Mean Utilization}

The mean utilization for the analyzed time period is reported for each site on Table 5.3. This is the best overall indicator of AAHX usage. Mean utilization was aggregated by climate zone and the results are presented in Table 5.4 . 


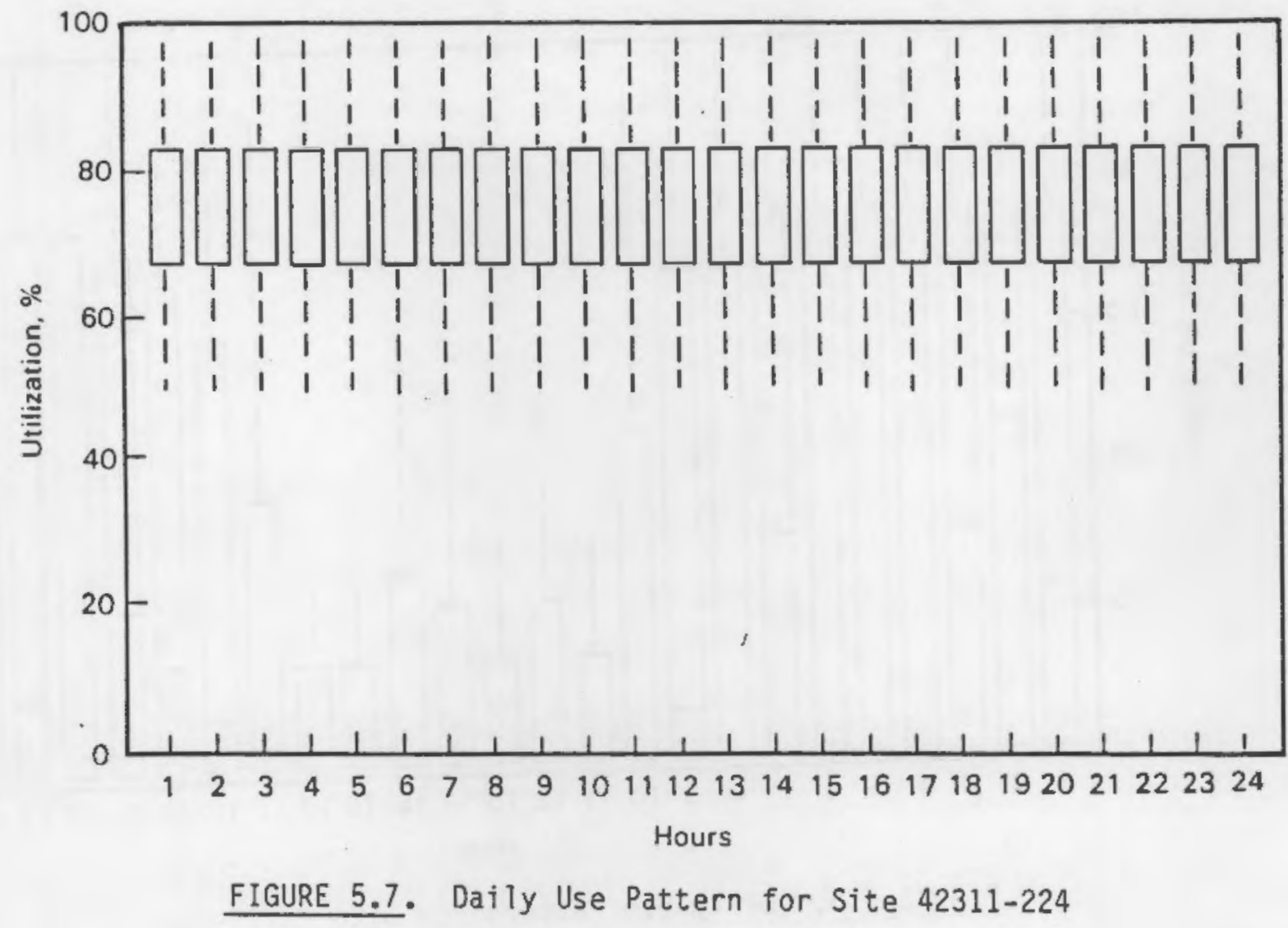

The aggregated results indicate that utilization appears to increase as one goes from warmer to colder climate zones. It had been hypothesized that AAHX utilization would decrease in colder climates but our data do not support this hypothesis. In addition, the large standard deviation relative to the mean should be noted. This indicated that there is a large variation in AAHX utilization.

\subsection{MEASURES OF THERMAL PERFORMANCE}

The coefficients of the linear fits to the plots of the various measures of thermal performance are presented in Table 5.5. The mean first law efficiency for the analyzed time period is reported in Table 5.3. As a summary of thermal performance, the mean first law efficiency was aggregated by climate zone and the results are reported Table 5.6.

The climate zone 3 sites were found to have a substantially lower mean first law efficiency but, due to the small sample size in climate zone 3 , it is 


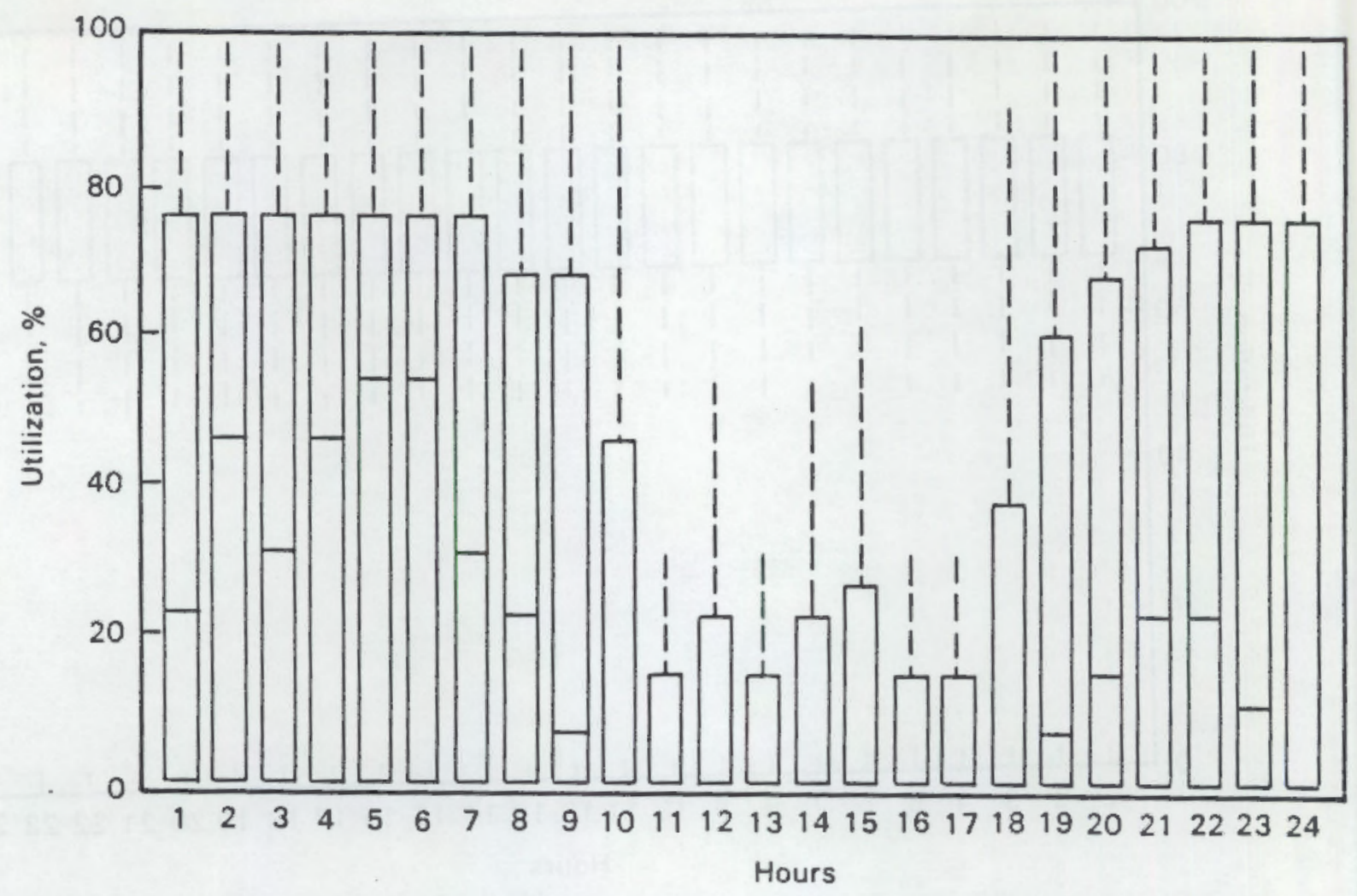

FIGURE 5.8. Daily Use Pattern for Site 23211-558

difficult to compare the results. Overall, the AAHX installations evaluated in this study have a mean first law efficiency of about $52 \%$.

Table 5.3 occasionally reports two mean efficiencies for one site. Two mean efficiencies are reported when the installation demonstrates a substantial change in efficiency. Only high utilization hours were used for calculating measures of thermal performance. Consequently the results are not truly a time series but they were analyzed sequentially. If something happened to change efficiency this would appear as a series of readings at the first efficiency followed by a series of readings at the new efficiency. This is shown on Figure 5.11 when the first law efficiency for 12111-117 is plotted as if it were a time series. Clearly something happened to cause a substantial increase in efficiency.

Many of the sites show an increase in the first law efficiency with decreasing $\Delta T$. Because heat exchanger theory indicates that the first law efficiency of the AAHX should be independent of $\Delta T$, it was hypothesized that 


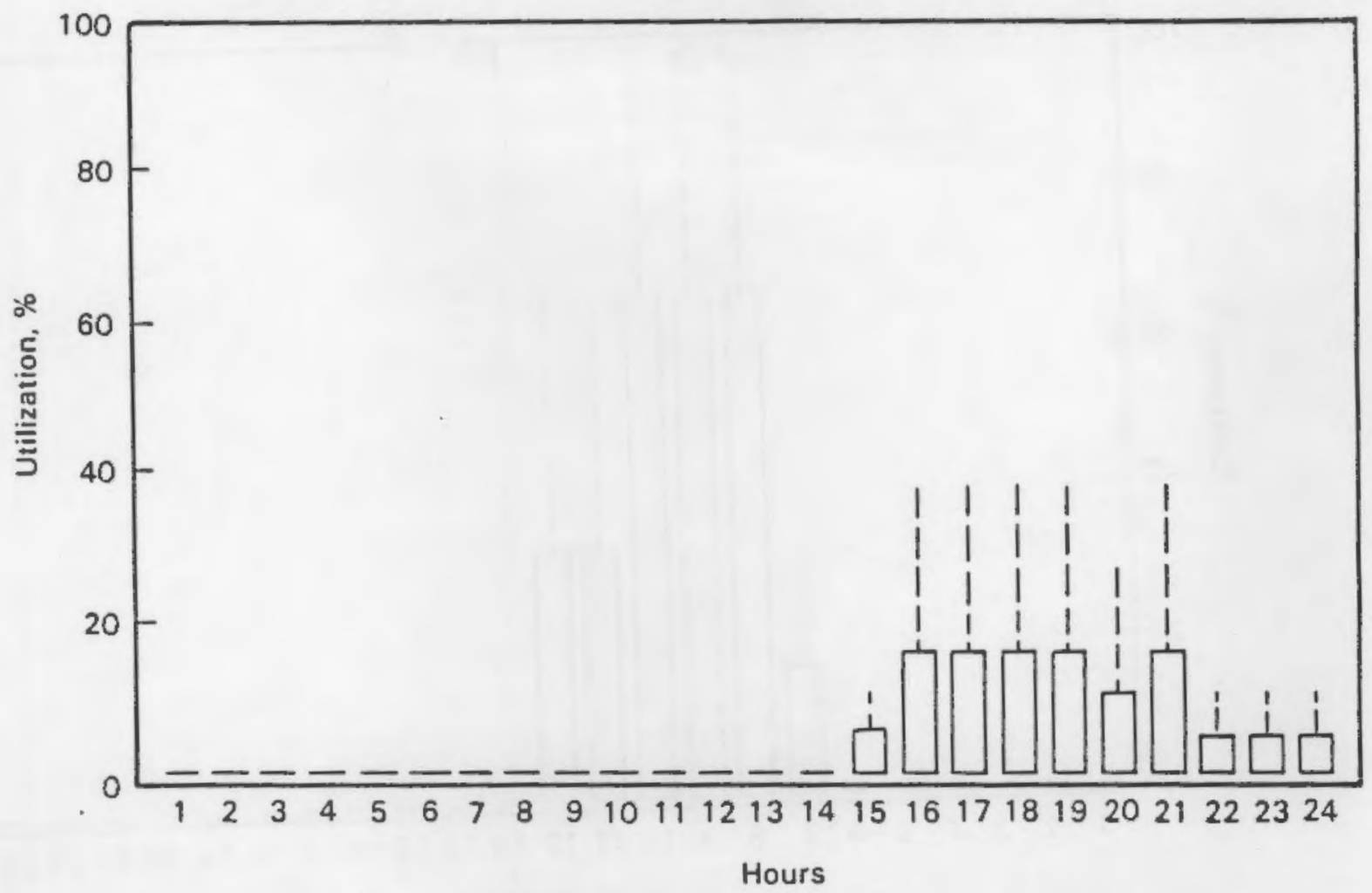

FIGURE 5.9. Daily Use Pattern for Site 42111-021

the of ten observed increase in first law efficiency could be caused by increased intake air flow such as would happen after filter cleaning. If filter cleaning was affecting first law efficiency then a plot of first law efficiency as a time series should show a gradual decrease in efficiency followed by a sudden jump which would be the result of the increased air flow associated with the filter cleaning. A review of time series first law efficiency data generally did not show this pattern. Two sites did show a sudden jump in efficiency that could be associated with filter cleaning, but a widespread impact of filter cleaning on first law efficiency was not observed.

\subsection{LATENT HEAT EFFECTS}

The impact of including latent heat effects on thermal performance is summarized on Table 5.7. Of the 22 sites analyzed for latent heat effects, eight were identified as having condensation during at least one of the high 


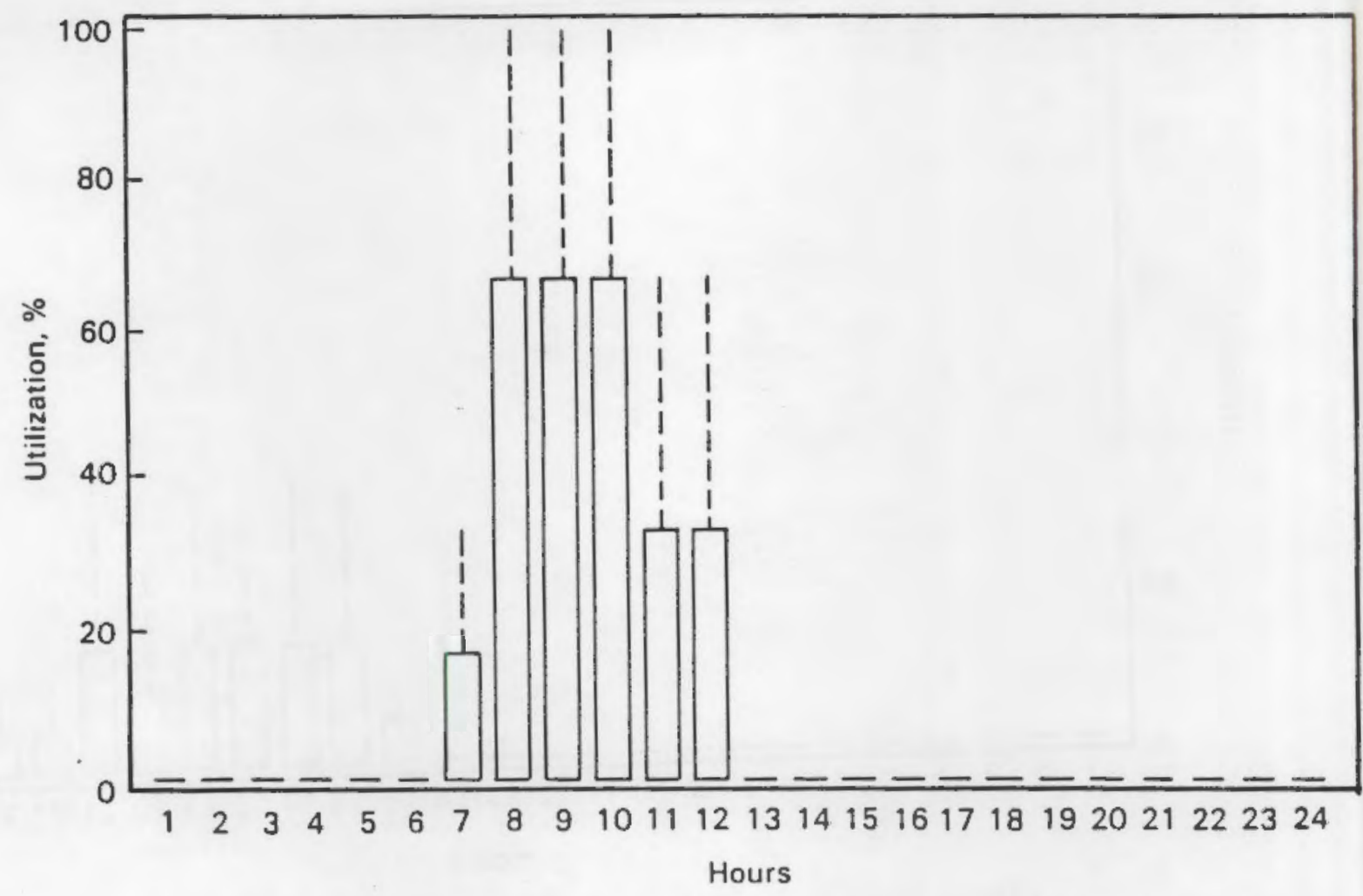

FIGURE 5.10. Daily Use Pattern for Site 41111-237

utilization hours. Three of the eight sites had only one hour with condensation. Due to the insignificant effect of such limited condensation, other indicators of latent heat transfer were not calculated for these sites. When condensation does occur, it can have a substantial impact on AAHX performance. The ratio of mean $Q_{s a v 1}$ to $Q_{\text {say }}$ shows that when condensation occurs, the displaced space heating energy consumption can be increased by approximately 15\%. In general, it does not appear that latent heat effects have a great impact on performance because condensation is rarely encountered. It should be noted that these calculations were conducted for hours with high utilization and not all available hours. It is possible that the selection of only high utilization hours may preferentially select hours without condensation, thus introducing a bias in the results. 
TABLE 5.3. Annual Performance of Air-to-Air Heat Exchanger Installations

\begin{tabular}{|c|c|c|c|c|c|c|c|c|c|}
\hline & & Averaglng & $\begin{array}{l}\text { Perlod } \\
\text { End }\end{array}$ & $\begin{array}{c}\text { Mean } \\
\text { Ut I I ization } \\
\text { h/day }\end{array}$ & $\begin{array}{r}\text { Mean } \\
\Delta \mathrm{T} \\
\therefore \mathrm{F} \\
\end{array}$ & $\begin{array}{l}\text { Moan } \\
\text { First Law } \\
\text { Efticiency }\end{array}$ & $\begin{array}{c}\text { Annual Space } \\
\text { MeatIng Energy } \\
\text { Savings, } \\
\text { kwh/yr } \\
\end{array}$ & $\begin{array}{c}\text { Annual AAHX } \\
\text { Energy } \\
\text { Consumption, } \\
\text { kwh/yr }\end{array}$ & $\begin{array}{c}\text { Ratlo of } \\
\text { Annual Space } \\
\text { Heatlng Savings } \\
\text { to AAHX Energy } \\
\text { ConsumptIon } \\
\end{array}$ \\
\hline $\begin{array}{l}12111-117 \\
12111-152 \\
12211-133 \\
12211-147 \\
12211-149 \\
23111-514 \\
23111-521 \\
23111-573 \\
23211-549 \\
23211-550 \\
23211-558 \\
31211-107 \\
31211-113 \\
31211-311 \\
31211-341 \\
31211-399 \\
32211-299 \\
41111-028 \\
41111-045 \\
41111-112 \\
41111-151 \\
41111-174 \\
41111-176 \\
411111-178 \\
41111-209 \\
41111-211 \\
41111-215 \\
41111-217 \\
41111-235 \\
411111-237 \\
41111-239 \\
41311-189 \\
41311-258 \\
42111-021 \\
42111-144 \\
42211-145 \\
42211-304 \\
42311-224\end{array}$ & $\begin{array}{l}11 \\
11 \\
11 \\
11\end{array}$ & $\begin{array}{c}\text { NA } \\
9 / 1 / 85 \\
1 / 28 / 86 \\
12 / 4 / 86 \\
9 / 1 / 85 \\
2 / 2 / 86 \\
10 / 27 / 85 \\
10 / 27 / 85 \\
1 / 9 / 85 \\
10 / 13 / 85 \\
10 / 2 / 85 \\
10 / 6 / 85 \\
1 / 9 / 85 \\
N A \\
9 / 1 / 85 \\
3 / 4 / 86 \\
10 / 4 / 85 \\
9 / 1 / 85 \\
1 / 27 / 86 \\
9 / 1 / 85 \\
1 / 9 / 85 \\
1 / 16 / 86 \\
9 / 1 / 85 \\
1 / 21 / 86 \\
3 / 20 / 86 \\
9 / 1 / 85 \\
11 / 24 / 85 \\
1 / 19 / 86 \\
11 / 24 / 85 \\
12 / 8 / 85 \\
1 / 9 / 85 \\
9 / 1 / 85 \\
1 / 9 / 85 \\
9 / 1 / 85 \\
10 / 12 / 85 \\
9 / 1 / 85 \\
9 / 1 / 85 \\
2 / 2 / 86 \\
1 / 5 / 86 \\
N A \\
11 / 24 / 85\end{array}$ & $\begin{array}{c}N A \\
4 / 26 / 86 \\
4 / 13 / 86 \\
4 / 26 / 86 \\
4 / 26 / 86 \\
4 / 12 / 86 \\
3 / 1 / 86 \\
3 / 1 / 86 \\
4 / 27 / 85 \\
4 / 27 / 86 \\
4 / 27 / 85 \\
4 / 13 / 86 \\
4 / 27 / 85 \\
N A \\
4 / 26 / 85 \\
4 / 19 / 86 \\
4 / 19 / 86 \\
4 / 27 / 86 \\
4 / 19 / 86 \\
4 / 12 / 86 \\
4 / 19 / 86 \\
4 / 23 / 86 \\
4 / 27 / 86 \\
4 / 19 / 86 \\
4 / 26 / 86 \\
4 / 27 / 86 \\
4 / 27 / 86 \\
4 / 12 / 86 \\
4 / 27 / 86 \\
4 / 27 / 86 \\
4 / 27 / 85 \\
4 / 12 / 86 \\
4 / 19 / 86 \\
3 / 15 / 86 \\
4 / 17 / 86 \\
4 / 12 / 86 \\
4 / 12 / 86 \\
4 / 12 / 86 \\
4 / 12 / 86 \\
N A \\
4 / 27 / 86\end{array}$ & $\begin{array}{c}\mathrm{NA} \\
2.3 \\
3.2 \\
2.9 \\
8.0 \\
19.2 \\
6.5 \\
9.0 \\
16.7 \\
8.8 \\
6.8 \\
6.7 \\
0.1 \\
\mathrm{NA} \\
23.3 \\
0 \\
9.2 \\
0.5 \\
1.4 \\
8.7 \\
3.4 \\
0.1 \\
3.3 \\
13.3 \\
0.7 \\
2.8 \\
0.2 \\
0.7 \\
6.2 \\
0.4 \\
9.5 \\
2.7 \\
17.8 \\
3.5 \\
1.7 \\
1.1 \\
22.5 \\
7.6 \\
15.3 \\
N A \\
16.7\end{array}$ & $\begin{array}{c}\text { NA } \\
41.9 \\
33.2 \\
30.9 \\
37.6 \\
24.1 \\
43.7 \\
42.1 \\
26.9 \\
32.7 \\
30.8 \\
31.4 \\
24.9 \\
N A \\
21.1 \\
16.5 \\
19.4 \\
27.1 \\
19.9 \\
22.5 \\
23.1 \\
29.3 \\
26.1 \\
20.7 \\
18.6 \\
25.2 \\
23.6 \\
25.1 \\
27.4 \\
23.9 \\
22.4 \\
25.8 \\
24.5 \\
27.3 \\
28.6 \\
37.7 \\
28.0 \\
25.4 \\
31.2 \\
N A \\
38.3\end{array}$ & $\begin{array}{l}0.358 \\
0.800 \\
0.774 \\
\text { NA } \\
0.695 \\
0.663 \\
0.697 \\
0.167 \\
\text { NA } \\
0.231 \\
\text { NA } \\
\text { NA } \\
\text { NA } \\
0.350 \\
0.423 \\
\text { NA } \\
0.585 \\
0.339 \\
0.600 \\
0.821 \\
\text { NA } \\
\text { NA } \\
0.683 \\
\text { NA } \\
\text { NA } \\
0.776 \\
0.102 \\
0.223 \\
0.378 \\
0.428 \\
\text { NA } \\
0.580 \\
\text { NA } \\
0.625 \\
\text { NA } \\
0.498 \\
0.343 \\
0.408 \\
0.451 \\
0.483 \\
0.796\end{array}$ & $\begin{array}{l}\text { NA } \\
483 \\
\text { NA } \\
\text { NA } \\
\text { NA } \\
\text { NA } \\
546 \\
\text { NA } \\
\text { NA } \\
721 \\
\text { NA } \\
\text { NA } \\
\text { NA } \\
\text { NA } \\
2056 \\
\text { NA } \\
\text { NA } \\
49 \\
-5 \\
1435 \\
\text { NA } \\
\text { NA } \\
455 \\
\text { NA } \\
\text { NA } \\
354 \\
\text { NA } \\
\text { NA } \\
\text { NA } \\
\text { NA } \\
\text { NA } \\
\text { NA } \\
\text { NA } \\
421 \\
\text { NA } \\
102 \\
1557 \\
\text { NA } \\
\text { NA } \\
\text { NA } \\
\text { NA }\end{array}$ & 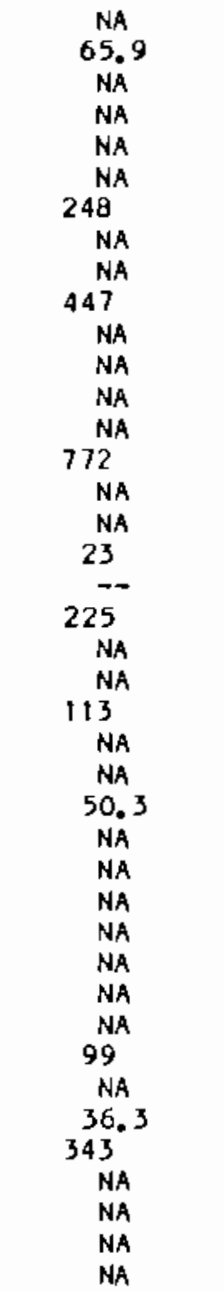 & $\begin{array}{l}\text { NA } \\
8.6 \\
\text { NA } \\
\text { NA } \\
\text { NA } \\
\text { NA } \\
2.2 \\
\text { NA } \\
\text { NA } \\
1.6 \\
\text { NA } \\
\text { NA } \\
\text { NA } \\
\text { NA } \\
2.7 \\
\text { NA } \\
\text { NA } \\
2.1 \\
:-1 \\
6.2 \\
\text { NA } \\
\text { NA } \\
4.2 \\
\text { NA } \\
\text { NA } \\
7.2 \\
\text { NA } \\
\text { NA } \\
\text { NA } \\
\text { NA } \\
\text { NA } \\
\text { NA } \\
\text { NA } \\
4.3 \\
\text { NA } \\
2.5 \\
4.5 \\
\text { NA } \\
\text { NA } \\
\text { NA } \\
\text { NA }\end{array}$ \\
\hline
\end{tabular}


IABLE 5.4. Mean Utilization of Air-to-Air Heat Exchangers by Climate Zone

\begin{tabular}{|c|c|c|}
\hline Climate Zone & I Climate Zone ? & Climate Zone 3 \\
\hline $\begin{array}{l}5.4 \\
3.1 \\
6.5 \\
20\end{array}$ & $\begin{array}{r}8.4 \\
5.4 \\
7.9 \\
12\end{array}$ & $\begin{array}{l}9.1 \\
7.8 \\
3.9 \\
6\end{array}$ \\
\hline
\end{tabular}

\subsection{ANNUAL ENERGY CONSUMPTION}

The calculation of annual energy consumption was attempted for 21 sites. Sufficient data existed to allow annual energy consumption calculations for 11 of the 21 sites. Tables presenting annual performance results are presented in Appendix $A$. The total annual displaced space-heating energy consumption, annual AAHX energy consumption, and mean ratio of displaced space-heating energy to AAHX electric energy consumption are reported in Table 5.3 . The aggregated results for the 11 sites are reported on Table 5.8 . The aggregations reported on Table 5.8 are for sites in all three climate zones combined.

The displaced space-heating energy consumption has a median value of $743 \mathrm{kWh} / \mathrm{yr}$. If this value is representative of the population of AAHX instal. lations, the cost effectiveness of AAHX installations must be seriously questioned. If power is available at $100 \mathrm{mil} / \mathrm{kWh}$, this would represent an energy savings of $\$ 74.30$ per year; however, assuming that AAHX power consumptions can be represented by the median value of $220 \mathrm{khh} / \mathrm{yr}$, the power required to run the AAHX will cost $\$ 22.90$ for a net savings of $\$ 51.40$. It is unlikely that this annual cost savings will recover the capital cost of the device. 
TABLE 5.5. Thermal Performance Characteristics

\begin{tabular}{|c|c|c|c|c|c|c|c|}
\hline \multirow[b]{3}{*}{ Site ID } & \multicolumn{2}{|c|}{$\begin{array}{c}\text { First Law Efficiency } \\
\text { Correlation } \\
\end{array}$} & \multicolumn{2}{|c|}{$\begin{array}{c}Q_{S a v} \\
\text { Correlation }\end{array}$} & \multirow{2}{*}{\multicolumn{2}{|c|}{$\begin{array}{l}\text { Inlet Temperature } \\
\text { Correlation }\end{array}$}} & \multirow{3}{*}{$\begin{array}{c}\text { Number of } \\
\text { High Utili- } \\
\text { zation } \\
\text { Hours } \\
\end{array}$} \\
\hline & \multirow[b]{2}{*}{$\begin{array}{l}x \text { Intercept } \\
\text { (decimal } \%)\end{array}$} & \multirow{2}{*}{$\left(\frac{\left.\begin{array}{c}\text { Slope } \\
\text { decimal } \%\end{array}\right)}{{ }^{0} \mathrm{C}}\right)$} & \multirow{2}{*}{$\left(\frac{k W h}{h}\right)$} & \multirow{2}{*}{$\begin{array}{l}\text { Slope } \\
\left(\frac{\mathrm{kwh}}{\mathrm{h}-0 \mathrm{C}}\right)\end{array}$} & & & \\
\hline & & & & & $\begin{array}{l}\text { Intercept } \\
{ }^{\circ} \mathrm{C} \\
\end{array}$ & $\begin{array}{l}\mathrm{S} 1 \text { ope } \\
{ }^{\circ} \mathrm{C} /{ }^{\circ} \mathrm{C}\end{array}$ & \\
\hline $12111-117$ I & 0.405 & -0.0028 & 0.119 & 0.0157 & 27.3 & -0.88 & 109 \\
\hline I I & 0.664 & 0.0065 & -0.005 & 0.0438 & 24.5 & -0.451 & 77 \\
\hline $1211-152^{(a)^{2}}$ & 0.581 & 0.0140 & -- & - & $\ldots$ & -- & 12 \\
\hline $12211-147$ & 0.600 & 0.0050 & - & -- & -- & - & 992 \\
\hline $1 ? 211-149$ & 0.407 & 0.0184 & 0.098 & 0.048 & 24.4 & -0.32 & 270 \\
\hline $23111-514$ & 0.758 & -0.0027 & 0.169 & 0.008 & 25.9 & -0.935 & 341 \\
\hline $3111-521$ & 0.278 & -0.0042 & 0.131 & 0.002 & 28.9 & -0.887 & 309 \\
\hline $23211-549$ & 0.082 & 0.0087 & 0.126 & 0.012 & 25.4 & -0.730 & 1199 \\
\hline $31211-1131$ & 0.353 & -0.0014 & 0.133 & 0.0164 & 22.3 & -0.727 & 2000 \\
\hline I I & 0.366 & -0.0043 & 0.092 & 0.0237 & 21.8 & -0.687 & 2635 \\
\hline $31211-341$ & 0.507 & 0.0072 & - & -- & - & -- & 3242 \\
\hline $31211-399$ & 0.136 & 0.0134 & 0.102 & 0.218 & 27.7 & -0.615 & 9 \\
\hline $32211-299$ & 0.545 & 0.0044 & -- & -- & - & -- & 79 \\
\hline $41111-028$ & 0.723 & 0.0052 & 0.057 & 0.0494 & 21.6 & -0.238 & 902 \\
\hline $41111-151$ & 0.573 & 0.0087 & 0.086 & 0.0360 & 27.1 & -0.731 & 98 \\
\hline $41111-178$ & 0.566 & 0.0152 & -0.040 & 0.0413 & 19.3 & -0.198 & 11 \\
\hline $41111-209$ & -0.119 & 0.0236 & 0.046 & 0.0166 & 21.1 & -0.512 & 13 \\
\hline $41111-211$ & 0.165 & 0.0065 & 0.097 & 0.0147 & 7.4 & -0.409 & 31 \\
\hline $41111-215$ & 0.402 & -0.0019 & 0.143 & 0.0124 & 23.3 & -0.606 & 928 \\
\hline $41111-217$ & 0.375 & 0.0042 & 0.105 & 0.0246 & 20.9 & -0.209 & 42 \\
\hline $41111-237$ & 0.444 & 0.0116 & 0.043 & 0.0191 & 21.2 & -0.296 & 143 \\
\hline $41311-189$ & 0.602 & 0.0015 & 0.090 & 0.0274 & 18.8 & -0.228 & 356 \\
\hline $42111-021$ & 0.501 & -0.0002 & 0.150 & 0.0084 & 32.6 & -0.733 & 17 \\
\hline $42111-144$ & 0.253 & 0.0052 & 0.034 & 0.0165 & 21.9 & -0.801 & 2431 \\
\hline $42211-145$ & 0.392 & 0.0011 & 0.056 & 0.0213 & 21.0 & -0.650 & 639 \\
\hline $42211-304$ & 0.551 & -0.0063 & 0.153 & 0.0120 & 25.9 & -0.776 & 439 \\
\hline $42371-2241$ & 0.585 & 0.0031 & 0.176 & 0.0123 & 30.9 & -0.553 & 288 \\
\hline I & 1.022 & -0.0140 & 0.229 & 0.0158 & 34.0 & -0.487 & 14 \\
\hline
\end{tabular}

(a) This site has unreasonable readings for air flows, which invalidated $Q_{s a v}$ and inlet temperature calculations. 
TABLE 5.6. Mean First Law Efficiency of Air-to-Air Heat Exchangers by Climate Zone

\begin{tabular}{ccc}
\multicolumn{3}{c}{ Mean First Law Efficiency } \\
\hline Climate Zone I & Climate Zone 2 & Climate Zone 3 \\
\cline { 3 - 3 } 0.50 & 0.60 & 0.37 \\
0.50 & 0.63 & 0.23 \\
0.22 & 0.17 & 0.29 \\
12 & 10 & 3
\end{tabular}

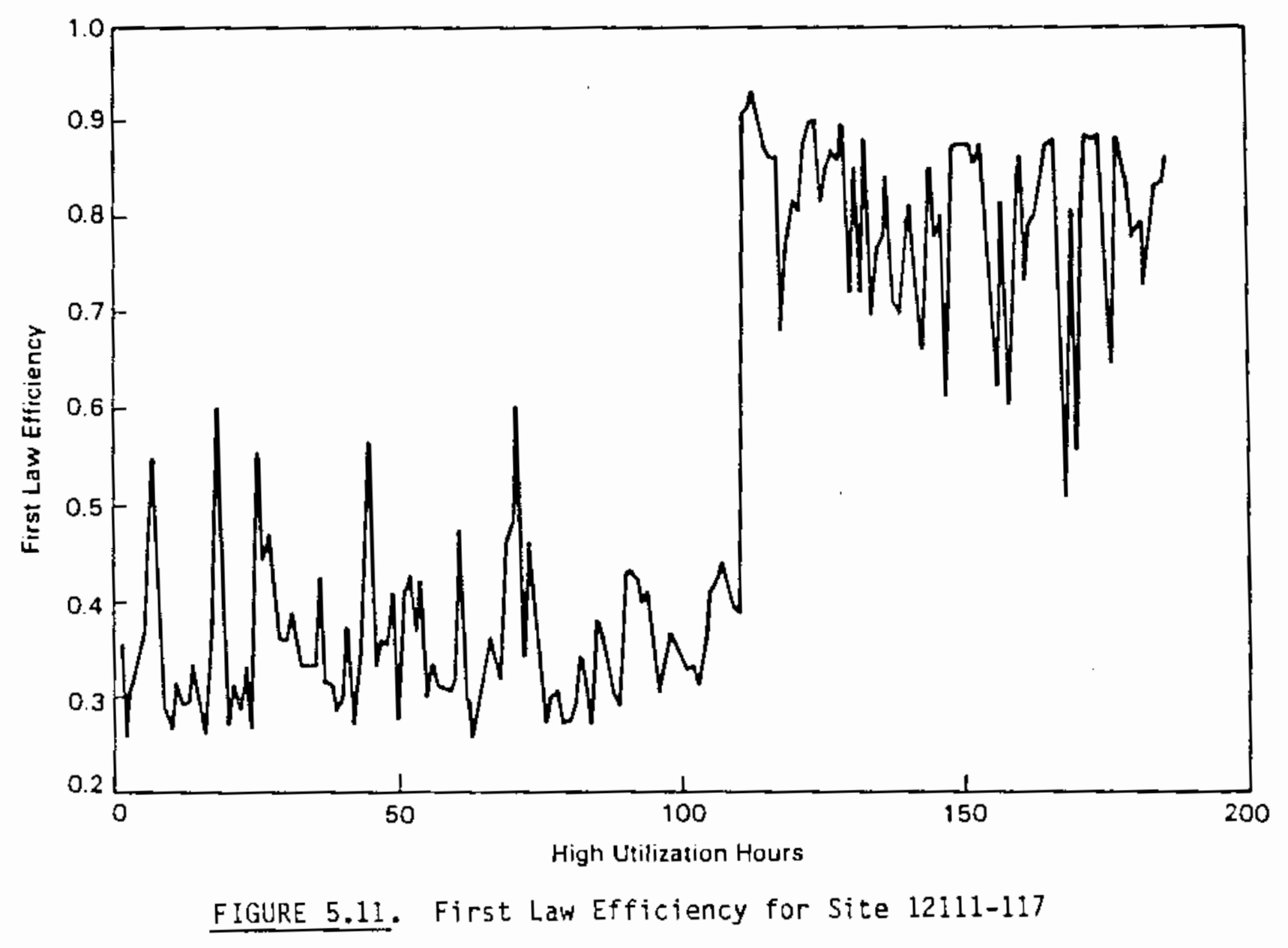


TABLE 5.7. Latent Heat Effects

\begin{tabular}{|c|c|c|c|c|}
\hline Site ID & $\begin{array}{c}\text { Number of Hours with } \\
\text { Exhaust Steam } \\
\text { Condensation }\end{array}$ & $\begin{array}{c}\text { Total Number } \\
\text { of Hours } \\
\end{array}$ & $\begin{array}{l}\text { Mean } \\
Q_{\text {Sayl }}\end{array}$ & $\begin{array}{c}\text { Mean } \\
Q_{\text {Say }} / Q_{\text {Say }} \\
\end{array}$ \\
\hline $12111-117$ & 92 & 306 & 1.24 & 1.18 \\
\hline $12111-152$ & no condensation & NA & NA & \\
\hline $12211-149$ & no condensation & NA & NA & \\
\hline $23111-514$ & 162 & 341 & 0.43 & 1.14 \\
\hline $23111-521$ & no condensation & NA & NA & \\
\hline $32111-549$ & 1 & 1200 & NA & NA \\
\hline $23211-113$ & no condensation & NA & NA & \\
\hline $31211-399$ & no condensation & NA & NA & \\
\hline $41111-028$ & 171 & 902 & 1.22 & 1.06 \\
\hline $41111-151$ & 20 & 98 & 0.89 & 1.19 \\
\hline $41111-178$ & 1 & 11 & NA & NA \\
\hline $41111-209$ & no condensation & NA & NA & \\
\hline $41111-211$ & no condensation & NA & NA & \\
\hline $41111-215$ & no condensation & NA & NA & \\
\hline $41111-217$ & no condensation & NA & NA & \\
\hline $41111-237$ & 28 & 131 & 0.43 & 1.16 \\
\hline $41311-189$ & 1 & 131 & NA & NA \\
\hline $42111-021$ & no condensation & NA & NA & \\
\hline $42111-144$ & no condensation & NA & NA & \\
\hline $42211-145$ & no condensation & NA & NA & \\
\hline $42211-304$ & no condensation & NA & NA & \\
\hline $42311-224$ & no condensation & NA & NA & \\
\hline
\end{tabular}

Mean

Median

Standard deviation

Number
TABLE 5.8. Annual Performance

\begin{tabular}{|c|c|c|}
\hline $\begin{array}{c}\text { Displaced Space Heating } \\
\text { Energy Consumption } \\
\left(0_{\text {sav }}\right), \mathrm{kWh} / \mathrm{yr} \\
\end{array}$ & $\begin{array}{c}\text { AAHX Energy } \\
\text { Consumption (AHE), } \\
\mathrm{kWh} / \mathrm{yr} \\
\end{array}$ & $\begin{array}{l}\text { Ratio of } \\
\text { Q } 5 \text { ay to AHE }\end{array}$ \\
\hline $\begin{array}{r}743 \\
483 \\
648 \\
11\end{array}$ & $\begin{array}{r}220 \\
113 \\
229 \\
11\end{array}$ & $\begin{array}{l}4.2 \\
4.2 \\
2.3 \\
11\end{array}$ \\
\hline
\end{tabular}




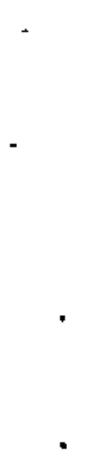




\subsection{CONCLUSIONS}

Section 6.1 will present conclusions concerning the results; Section 6.2 will present conclusions concerning the methods of analysis.

6.1 CONCLUSIONS CONCERNING RESULTS

The results of the AAHX analysis have been reviewed by PNL and the following conclusions drawn:

- Annual Utilization--There is a wide variation in AAHX utilization. Some installations are used constantly while others are either used intermittently or not at all. Most AAHX installations do not show a clear annual utilization pattern but a significant subset demonstrates tigntly controlled utilization. In general, annual utilization does not show seasonal variations. This sliggests that AAHX utilization is not strangly influenced by seasonal effects such as variation in outside temperature.

- Typical Daily use Patterns--The most important conclusion from the review of typical daily use patterns is the lack of any dominant use pattern. Individual owners use their AAHX installations in a variety of ways. The most common pattern is corstant utilization throughout a typical day.

- Mean Utilization--lhen all AAHX installations are considered, the mean utilization implies that an average AAHX installation would be operated approximately 7 hours per day but there is a large variation in the results as reflected by a large standard deviation. The results from the availabie sample do not show a decrease in AAHX utilization as one moves fron climate zone 1 to the colder clinate zones.

- First Law Efficiency--lihen all AAHX installations are considered, the mean first law efficiency is $52 \%$ with a large standard deviation. A 
review of hourly first law efficiency data arranged sequentially does not show a widespread impact of filter cleaning on first law efficiency.

- Latent Heat Effects--Based on our calculated results, latent heat effects did not have a significant impact on performance. This was caused by the limited number of high utilization hours with condensation.

- Displaced Annual Space Heating Energy--For the available sample, the mean annual displaced space-heating energy consumption is $743 \mathrm{kWh} / \mathrm{yr}$ while the mean annual AAHX energy consumption was $220 \mathrm{kWh} / \mathrm{yr}$. In both cases the standard deviations are very large when compared to the mean values.

The general impression resulting from this study is that the owners of AAHX installations operate their devices in a wide variety of ways. This results in a large variation in mean utilization and the lack of a dominant pattern in utilization during a typical day.

\subsection{CONCLUSIONS CONCERNING ANALYSIS METHOD}

Given the nature and amount of the available data, the method used in this report is appropriate but future monitoring of AAHX installations may profit by lessons learned in this study, such as the following.

- AAHX on/off indication--Any caiculation concerning AAHX performance is only relevant for periods when the device is operating. Future testing should include some method of selectively recording data for periods of operations. This would avoid having to identify high utilization time periods.

- Continuous Air Flow Monitoring--The lack of continuous air flow data seriously compromises the calculations that require air flow data, such as TIA and $Q_{S a v}$. Other measures of performance such as utilization and first law efficiency do not depend on air flow measurements and can be used with more confidence. 
- Latent Heat Effects--This study indicates that latent heat effects may not have a large impact on overall performance. If this finding is confirmed by other field tests of AAHX installations, this may suggest that humidity and condensate measurements are not required. 


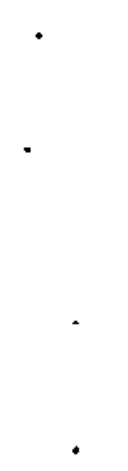




\subsection{REFERENCES}

Alexander, R. 1985. "Measured Performance of a Central Air-to-Air-Heat Recovery Ventilation System." Paper presented at Conservation in Buildings: Northwest Perspective, May 19-22, 1985, Butte, Montana.

Becker, R. A., and J. M. Chambers. 1984. S, An Interactive Environment for Data Analysis and Graphics. Wadsworth Advanced Books, Belmont, California.

Fisk, W. J., and I. Turiel. 1983. "Residential Air-to-Air Heat Exchangers: Performance, Energy Savings, and Economics. Energy and Buildings, 5:197-211.

National Center for Appropriate Technology (NCAT). 1984. Heat Recovery Ventilation for Housing: Air-to-Air Heat Exchangers. DOE/CE/15095-9, Butte, Montana.

Reiland, P., M. Mckinstry, and P. Thor. 1985. Preliminary Air-to-Air Meat Exchangers Testing Results for the Residential Standards Demonstration Programs. Office of Conservation, Bonneville Power Administration, Portland, oregon.

Schaub, David. 1983. Air-to-Air Meat Exchangers. EY3100, Washington State Energy office, Washington State Energy Extension Service, Snohomish Public Utility District, Snohomish, Washington.

Shurcliff, William A. 1982. Air-to-Air Heat Exchangers for Houses. Brick House Publishing Company, Andover, Massachusetts.

Van Wylen, G. J., and R. E. Sonntag. 1973. Fundamentals of Classical Thermodynamics. John Wiley and Sons, Inc., New York. 


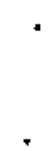


APPENDIX A

ANNUAL THERIAAL PERFORMANCE OF INOIVIOUAL SITES 


\section{Site ID 12111-117 Thermal Performance}

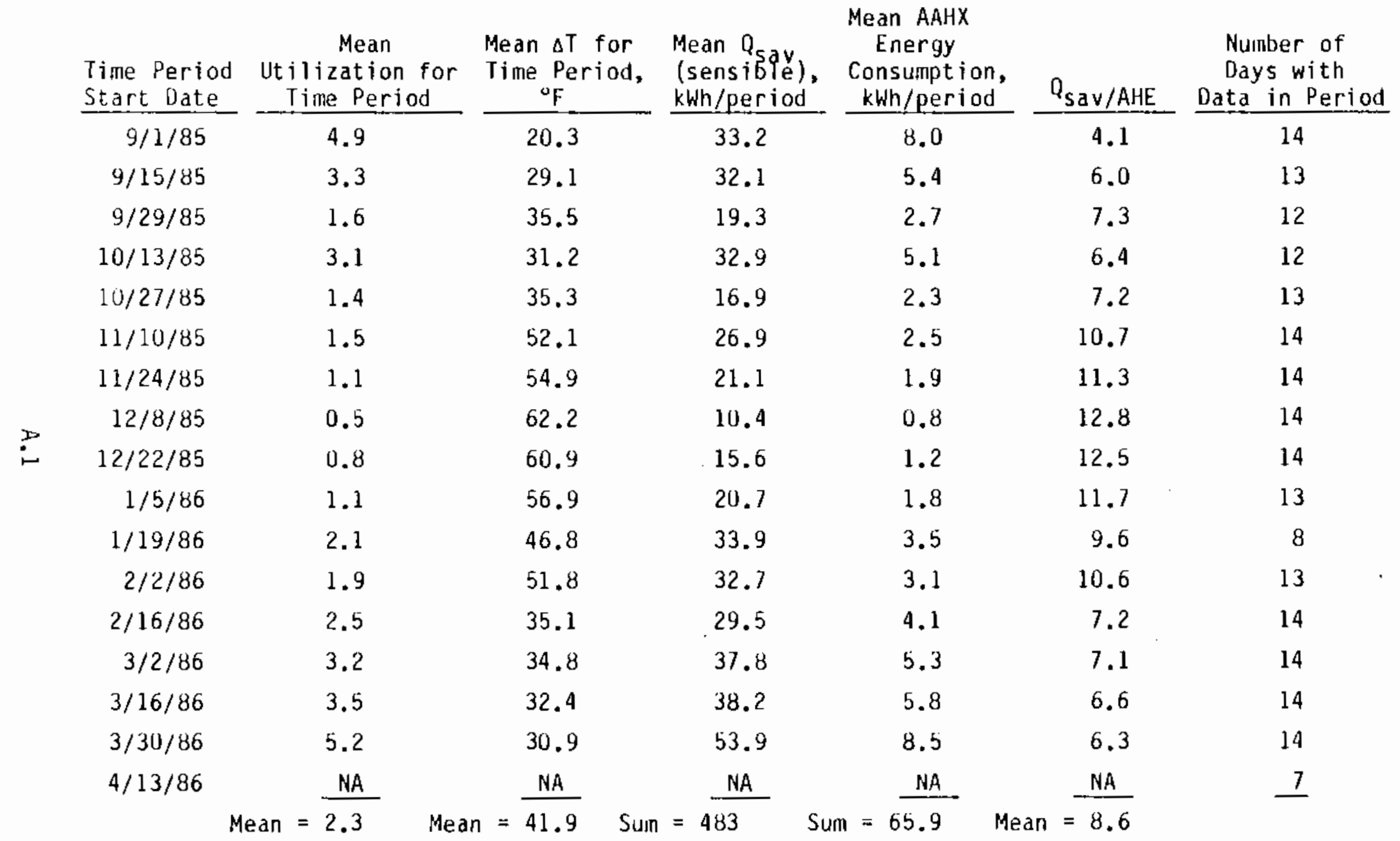


Site I0 12211-149 Thermal Performance

\begin{tabular}{|c|c|c|c|c|c|c|}
\hline $\begin{array}{l}\text { Time Period } \\
\text { Start Date }\end{array}$ & $\begin{array}{c}\text { Mean } \\
\text { Utilization for } \\
\text { Time Period } \\
\end{array}$ & $\begin{array}{l}\text { Mean } \Delta T \text { for } \\
\text { Time Period, } \\
\text { of }\end{array}$ & $\begin{array}{l}\text { Mean } Q_{\text {sav }} \\
\text { (sensibie), } \\
\text { kWh/period }\end{array}$ & $\begin{array}{l}\text { Mean AAHX } \\
\text { Energy } \\
\text { Consumption, } \\
\text { kWh/period }\end{array}$ & $Q_{\text {Sav } / A H E}$ & $\begin{array}{c}\text { Number of } \\
\text { Days with } \\
\text { Data in Period }\end{array}$ \\
\hline $9 / 1 / 85$ & NA & NA & NA & NA & NA & 0 \\
\hline $9 / 15 / 85$ & NA & NA & NA & NA & NA & 0 \\
\hline $9 / 29 / 85$ & NA & NA & NA & NA & NA & 0 \\
\hline $10 / 13 / 85$ & NA & NA & NA & NA & NA & 0 \\
\hline $10 / 27 / 85$ & NA & NA & NA & NA & NA & 0 \\
\hline $11 / 10 / 85$ & NA & NA & NA & NA & NA & 0 \\
\hline $11 / 24 / 85$ & NA & NA & NA & NA & NA & 0 \\
\hline $12 / 8 / 85$ & NA & NA & NA & NA & NA & 0 \\
\hline $12 / 22 / 85$ & NA & NA & NA & NA & NA & 0 \\
\hline $1 / 5 / 86$ & NA & $\mathrm{NA}$ & NA & NA & NA & 0 \\
\hline $1 / 19 / 86$ & NA & NA & NA & NA & NA & 0 \\
\hline $2 / 2 / 86$ & 19.6 & 34.2 & 279.5 & 66.2 & 4.2 & 11 \\
\hline $2 / 16 / 86$ & 19.6 & 22.5 & 192.6 & 65.9 & 2.9 & 4 \\
\hline $3 / 2 / 86$ & 18.8 & 23.2 & 189.8 & 63.5 & 3.0 & 14 \\
\hline $3 / 16 / 86$ & 18.9 & 20.7 & 173.1 & 63.9 & 2.7 & 14 \\
\hline $3 / 30 / 86$ & 19.2 & 19.9 & 170.2 & 64.9 & 2.6 & 14 \\
\hline $4 / 13 / 86$ & $\mathrm{NA}$ & NA & $\mathrm{NA}$ & NA & NA & 7 \\
\hline & $n=\overline{19.2}$ & $n=\overline{24.1}$ & $\mathrm{um}=\mathrm{NA}$ & Sum $=N A$ & $n=3.1$ & \\
\hline
\end{tabular}


Site ID 23111-514 Thermal Performance

\begin{tabular}{|c|c|c|c|c|c|c|}
\hline $\begin{array}{l}\text { Time Period } \\
\text { Start Date }\end{array}$ & $\begin{array}{c}\text { Mean } \\
\text { Utilization for } \\
\text { Time Period } \\
\end{array}$ & $\begin{array}{l}\text { Mean } \Delta \mathrm{T} \text { for } \\
\text { Time Period, } \\
{ }^{\circ} \mathrm{F}\end{array}$ & $\begin{array}{l}\text { Mean Qsav } \\
\text { (sensible), } \\
\text { kwh/period }\end{array}$ & $\begin{array}{l}\text { Mean AAHX } \\
\text { Energy } \\
\text { Consumption, } \\
\text { kWh/period } \\
\end{array}$ & $a_{\text {Sav/AHE }}$ & $\begin{array}{c}\text { Number of } \\
\text { Days with } \\
\text { Data in Period }\end{array}$ \\
\hline $9 / 1 / 85$ & NA & NA & NA & NA & NA & 0 \\
\hline $9 / 15 / 85$ & NA & NA & NA & NA & NA & 0 \\
\hline $9 / 29 / 85$ & NA & NA & NA & NA & NA & 0 \\
\hline $10 / 13 / 85$ & NA & NA & NA & NA & NA & 0 \\
\hline $10 / 27 / 85$ & NA & NA & NA & NA & NA & 3 \\
\hline $11 / 10 / 85$ & 4.8 & 58.5 & 28.2 & 10.7 & 2.6 & 10 \\
\hline $11 / 24 / 85$ & 4.8 & 62.3 & 29.7 & 10.9 & 2.7 & 14 \\
\hline $12 / 8 / 85$ & 5.2 & 51.9 & 28.5 & 11.7 & 2.4 & 13 \\
\hline $12 / 22 / 85$ & 5.1 & 52.9 & 28.7 & 11.6 & 2.5 & 14 \\
\hline $1 / 5 / 86$ & 7.2 & 44.4 & 36.6 & 16.3 & 2.2 & 13 \\
\hline $1 / 19 / 86$ & 7.9 & 42.1 & 38.8 & 17.7 & 2.2 & 13 \\
\hline $2 / 2 / 86$ & 8.0 & 52.9 & 44.6 & 18.0 & 2.5 & 13 \\
\hline $2 / 16 / 86$ & 6.9 & 36.4 & 31.7 & 15.6 & 2.0 & 14 \\
\hline $3 / 2 / 86$ & 8.3 & 34.7 & 37.0 & 18.6 & 2.0 & 8 \\
\hline $3 / 16 / 86$ & 5.6 & 30.1 & 23.4 & 12.6 & 1.9 & 14 \\
\hline $3 / 30 / 86$ & 6.2 & 30.8 & 26.1 & 13.9 & 1.9 & 10 \\
\hline $4 / 13 / 86$ & 7.9 & 28.4 & 32.4 & 17.8 & 1.8 & 8 \\
\hline & $a n=\overline{6.5}$ & $n=\overline{43.7}$ & $=5 \overline{446}$ & $n=248$ Mean & $=2.2$ & \\
\hline
\end{tabular}


Site 10 23111-521 Thermal Performance

\begin{tabular}{|c|c|c|c|c|c|c|}
\hline $\begin{array}{l}\text { Time Period } \\
\text { Start Date }\end{array}$ & $\begin{array}{l}\text { Mean } \\
\text { Utilization for } \\
\text { rime Period } \\
\end{array}$ & $\begin{array}{l}\text { Mean } \Delta T \text { for } \\
\text { Time Period, } \\
{ }^{\circ} \mathrm{F} \\
\end{array}$ & $\begin{array}{l}\text { Mean } Q_{\text {Say }} \\
\text { (sensible), } \\
\text { kwh/period }\end{array}$ & $\begin{array}{l}\text { Mean AAHX } \\
\text { Energy } \\
\text { Consumption, } \\
\text { kWh/perjod }\end{array}$ & $\mathrm{Q}_{\mathrm{Sav} / \mathrm{AHE}}$ & $\begin{array}{c}\text { Number of } \\
\text { Days with } \\
\text { Data in Period }\end{array}$ \\
\hline $9 / 1 / 85$ & NA & NA & NA & NA & NA & 0 \\
\hline $9 / 15 / 85$ & NA & NA & NA & NA & NA & 0 \\
\hline $9 / 29 / 85$ & NA & NA & NA & NA & NA & 0 \\
\hline $10 / 13 / 85$ & NA & NA & NA & NA & NA & 0 \\
\hline $10 / 27 / 85$ & 3.1 & 32.0 & 7.4 & 5.5 & 1.3 & 7 \\
\hline $11 / 10 / 85$ & 6.3 & 47.8 & 17.1 & 11.3 & 1.5 & 14 \\
\hline $11 / 24 / 85$ & 7.2 & 52.9 & 20.3 & 12.9 & 1.6 & 13 \\
\hline $12 / 8 / 85$ & 9.1 & 49.9 & 25.1 & 16.4 & 1.5 & 14 \\
\hline $12 / 22 / 85$ & 8.6 & 48.8 & 23.5 & 15.5 & 1.5 & 13 \\
\hline $1 / 5 / 86$ & 17.2 & 40.0 & 44.4 & 31.1 & 1.4 & 13 \\
\hline $1 / 19 / 86$ & 10.4 & 36.4 & 26.2 & 18.9 & 1.4 & 14 \\
\hline $2 / 2 / 86$ & 10.7 & 40.8 & 27.9 & 19.4 & 1.4 & 13 \\
\hline $2 / 16 / 86$ & 8.8 & 30.5 & 21.2 & 15.0 & 1.3 & 12 \\
\hline $3 / 2 / 86$ & NA & NA & NA & NA & NA & 2 \\
\hline $3 / 16 / 86$ & NA & NA & NA & NA & NA & 0 \\
\hline $3 / 30 / 86$ & NA & NA & $N A$ & NA & NA & 0 \\
\hline $4 / 13 / 86$ & NA & NA & NA & NA & NA & $\underline{0}$ \\
\hline & ean $=9.0$ & $n=42.1$ & $u m=N A$ & SuIn $=N A$ & $1=1.5$ & \\
\hline
\end{tabular}


Site ID 23211-549 Therinal Performance

\begin{tabular}{|c|c|c|c|c|c|c|}
\hline $\begin{array}{l}\text { Time Period } \\
\text { Start Date }\end{array}$ & $\begin{array}{c}\text { Mean } \\
\text { Utilization for } \\
\text { Time Period } \\
\end{array}$ & $\begin{array}{l}\text { Mean } \Delta T \text { for } \\
\text { Time Period, } \\
{ }_{0}= \\
\end{array}$ & $\begin{array}{l}\text { Mean } Q_{\text {say }} \\
\text { (sensible), } \\
\text { kwh/period }\end{array}$ & $\begin{array}{l}\text { Mean AAHX } \\
\text { Energy } \\
\text { Consumption, } \\
\text { kWh/period } \\
\end{array}$ & $0_{\text {Sav } / A H E}$ & $\begin{array}{c}\text { Number of } \\
\text { Days with } \\
\text { Data in Period }\end{array}$ \\
\hline $9 / 1 / 85$ & NA & NA & NA & $N A$ & NA & 0 \\
\hline $9 / 15 / 35$ & NA & NA & NA & NA & NA & 0 \\
\hline $9 / 29 / 85$ & NA & NA & NA & $N A$ & NA & 0 \\
\hline $10 / 13 / 85$ & 15.8 & 23.5 & 63.6 & 47.3 & 1.3 & 11 \\
\hline $10 / 27 / 85$ & 13.3 & 26.7 & 57.8 & 39.8 & 1.4 & 12 \\
\hline $11 / 10 / 85$ & 5.7 & 44.5 & 34.8 & 17.2 & 2.0 & 12 \\
\hline $11 / 24 / 85$ & 9.5 & 43.1 & 56.0 & 28.3 & 2.0 & 14 \\
\hline $12 / 8 / 85$ & 6.0 & 43.3 & 35.4 & 17.8 & 2.0 & 14 \\
\hline $12 / 22 / 85$ & 9.8 & 44.1 & 48.9 & 29.3 & 2.0 & 10 \\
\hline $1 / 5 / 86$ & 9.5 & 37.5 & 51.1 & 28.4 & 1.8 & 13 \\
\hline $1 / 19 / 86$ & 7.5 & 34.6 & 38.3 & 22.5 & 1.7 & 14 \\
\hline $2 / 2 / 86$ & 7.0 & 37.7 & 37.9 & 21.0 & 1.8 & 14 \\
\hline $2 / 16 / 86$ & 7.5 & 30.6 & 35.2 & 22.4 & 1.6 & 13 \\
\hline $3 / 2 / 86$ & 7.4 & 27.2 & 32.7 & 22.3 & 1.6 & 10 \\
\hline $3 / 16 / 86$ & 8.4 & 23.6 & 34.1 & 25.3 & 1.3 & 14 \\
\hline $3 / 30 / 86$ & 9.0 & 21.6 & 34.4 & 26.8 & 1.2 & 13 \\
\hline $4 / 13 / 86$ & 6.4 & 20.0 & 23.8 & 19.3 & 1.2 & 9 \\
\hline & Mean $=\overline{8.8}$ & $=\overline{32.7}$ & $=721$ & $=4 \overrightarrow{47}$ & $=1.6$ & \\
\hline
\end{tabular}


Site ID 31211-113 Thermal Performance

\begin{tabular}{|c|c|c|c|c|c|c|}
\hline $\begin{array}{l}\text { Time Period } \\
\text { Start Date }\end{array}$ & $\begin{array}{c}\text { Mean } \\
\text { Utilization for } \\
\text { Time Period } \\
\end{array}$ & $\begin{array}{c}\text { Mean } \Delta T \text { for } \\
\text { Time Period, } \\
\text { of }\end{array}$ & $\begin{array}{l}\text { Mean } Q_{\text {sav }} \\
\text { (sensible), } \\
\text { kWh/period } \\
\end{array}$ & $\begin{array}{l}\text { Mean AAHX } \\
\text { Energy } \\
\text { Consumption, } \\
\text { kWh/period } \\
\end{array}$ & $Q_{\text {Sav/AHE }}$ & $\begin{array}{c}\text { Number of } \\
\text { Days with } \\
\text { Data in Period }\end{array}$ \\
\hline $9 / 1 / 85$ & 23.0 & 10.0 & 72.2 & 44.8 & 1.6 & 6 \\
\hline $9 / 15 / 85$ & 22.8 & 9.9 & 71.2 & 44.5 & 1.6 & 13 \\
\hline $9 / 29 / 85$ & 22.6 & 14.6 & 90.1 & 44.0 & 2.0 & 14 \\
\hline $10 / 13 / 85$ & 22.5 & 14.9 & 90.9 & 43.8 & 2.1 & 14 \\
\hline $10 / 27 / 85$ & 22.3 & 18.5 & 105.3 & 43.5 & 2.4 & 12 \\
\hline $11 / 10 / 85$ & 22.4 & 30.9 & 156.9 & 43.7 & 3.6 & 13 \\
\hline $11 / 24 / 85$ & 22.7 & 33.9 & 171.4 & 44.3 & 3.9 & 12 \\
\hline $12 / 8 / 85$ & 22.6 & 34.1 & 171.3 & 43.9 & 3.9 & 13 \\
\hline $12 / 22 / 85$ & 24.0 & 32.6 & 175.6 & 46.8 & 3.8 & 13 \\
\hline $1 / 5 / 86$ & 24.0 & 22.5 & 130.6 & 46.7 & 2.8 & 13 \\
\hline $1 / 19 / 86$ & 24.0 & 23.1 & 133.2 & 46.8 & 2.8 & 14 \\
\hline $2 / 2 / 86$ & 24.0 & 25.5 & 144.1 & 46.8 & 3.1 & 14 \\
\hline $2 / 16 / 86$ & 24.1 & 17.9 & 110.6 & 46.9 & 2.4 & 13 \\
\hline $3 / 2 / 86$ & 24.0 & 17.2 & 107.2 & 46.7 & 2.3 & 14 \\
\hline $3 / 16 / 86$ & NA & NA & NA & NA & NA & 7 \\
\hline $3 / 30 / 86$ & 24.0 & 16.9 & 105.8 & 46.7 & 2.3 & 13 \\
\hline $4 / 13 / 86$ & 23.8 & 15.5 & 98.7 & 46.3 & 2.1 & 14 \\
\hline & $\Rightarrow 23.3$ & $=21.1$ & 2056 & 772 & $m=2.7$ & \\
\hline
\end{tabular}


Site 10 31211-399 Thermal Performance

\begin{tabular}{|c|c|c|c|c|c|c|}
\hline $\begin{array}{l}\text { Time Period } \\
\text { Start Date }\end{array}$ & $\begin{array}{c}\text { Mean } \\
\text { Utilization for } \\
\text { Time Period } \\
\end{array}$ & $\begin{array}{c}\text { Mean } \Delta T \text { for } \\
\text { Time Period, } \\
{ }^{\circ} \mathrm{F} \\
\end{array}$ & $\begin{array}{l}\text { Mean } Q_{\text {say }} \\
\text { (sensibie), } \\
\text { kWh/period } \\
\end{array}$ & $\begin{array}{c}\text { Mean AAHX } \\
\text { Energy } \\
\text { Consumption, } \\
\text { kWh/period }\end{array}$ & $Q_{\text {Sav/AHE }}$ & $\begin{array}{c}\text { Number of } \\
\text { Days with } \\
\text { Data in Period } \\
\end{array}$ \\
\hline $9 / 1 / 85$ & 0.4 & 13.2 & 1.3 & 1.D & 1.3 & 14 \\
\hline $9 / 15 / 85$ & 0.5 & 16.5 & 2.1 & 1.4 & 1.5 & 13 \\
\hline $9 / 29 / 85$ & 0.3 & 20.0 & 1.6 & 0.9 & 1.7 & 14 \\
\hline $10 / 13 / 85$ & 0.6 & 20.6 & 3.2 & 1.8 & 1.8 & 12 \\
\hline $10 / 27 / 85$ & 0.5 & 24.7 & 3.0 & 1.5 & 2.0 & 14 \\
\hline $11 / 10 / 85$ & 0.3 & 38.9 & 2.1 & 0.7 & 2.9 & 14 \\
\hline $11 / 24 / 85$ & 0.3 & 38.7 & 2.5 & D. 9 & 2.8 & 12 \\
\hline $12 / 8 / 85$ & 0.4 & 42.7 & 3.1 & 1.0 & 3.1 & 14 \\
\hline $12 / 22 / 85$ & 1.2 & 40.6 & 9.6 & 3.3 & 3.0 & 13 \\
\hline $1 / 5 / 86$ & 0.2 & 29.0 & 1.2 & 0.6 & 2.3 & 14 \\
\hline $1 / 19 / 86$ & 0.1 & 26.2 & 0.6 & 0.3 & 2.1 & 14 \\
\hline $2 / 2 / 86$ & 0.1 & 29.0 & 0.7 & 0.3 & 2.3 & 13 \\
\hline $2 / 16 / 86$ & 0.6 & 25.3 & 3.7 & 1.8 & 2.0 & 14 \\
\hline $3 / 2 / 86$ & 0.4 & 24.0 & 2.0 & 1.0 & 2.0 & 14 \\
\hline $3 / 16 / 86$ & 0.9 & 23.1 & 5.1 & 2.7 & 1.9 & 14 \\
\hline $3 / 30 / 86$ & 0.6 & 24.7 & 3.2 & 1.6 & 2.0 & 14 \\
\hline $4 / 13 / 86$ & 0.8 & 23.5 & 4.3 & 2.2 & 1.9 & 14 \\
\hline & $n=0.5$ & $=27.1$ & $=49.0$ & $n=22.9$ & $=2.1$ & \\
\hline
\end{tabular}


Site ID 41111-028 Thermal Performance

\begin{tabular}{|c|c|c|c|c|c|c|}
\hline $\begin{array}{l}\text { Time Period } \\
\text { Start Date }\end{array}$ & $\begin{array}{c}\text { Mean } \\
\text { Utilization for } \\
\text { Time Period } \\
\end{array}$ & $\begin{array}{l}\text { Mean } \Delta T \text { for } \\
\text { Time Period, } \\
{ }^{\circ} \mathrm{F} \\
\end{array}$ & $\begin{array}{l}\text { Mean } Q_{\text {sav }} \\
\text { (sensible), } \\
\text { kWh/period } \\
\end{array}$ & $\begin{array}{l}\text { Mean AAHX } \\
\text { Energy } \\
\text { Consumption, } \\
\text { kwh/period } \\
\end{array}$ & $Q_{\text {sav/AHE }}$ & $\begin{array}{c}\text { Number of } \\
\text { Days with } \\
\text { Data in Period }\end{array}$ \\
\hline $9 / 1 / 85$ & 12.9 & 11.0 & 64.5 & 19.6 & 3.3 & 13 \\
\hline $9 / 15 / 85$ & 12.2 & 13.7 & 73.7 & 18.6 & 4.0 & 13 \\
\hline $9 / 29 / 85$ & 9.3 & 15.9 & 64.2 & 14.2 & 4.5 & 13 \\
\hline $10 / 13 / 85$ & 0.5 & 16.2 & 3.2 & 0.7 & 4.6 & 12 \\
\hline $10 / 27 / 35$ & 19.7 & 21.8 & 180.9 & 30.1 & 6.0 & 14 \\
\hline $11 / 10 / 85$ & NA & NA & NA & NA & NA & 7 \\
\hline $11 / 24 / 85$ & 14.4 & 35.3 & 206.0 & 21.9 & 9.4 & 11 \\
\hline $12 / 8 / 85$ & 11.1 & 34.2 & 155.1 & 16.9 & 9.1 & 14 \\
\hline $12 / 22 / 85$ & 12.1 & 32.4 & 160.4 & 18.5 & 8.7 & 13 \\
\hline $1 / 5 / 86$ & 5.5 & 22.8 & 52.4 & 8.4 & 6.3 & 11 \\
\hline $1 / 19 / 86$ & 5.2 & 23.4 & 50.7 & 7.9 & 6.4 & 13 \\
\hline $2 / 2 / 86$ & 5.1 & 28.9 & 60.7 & 7.8 & 7.8 & 14 \\
\hline $2 / 16 / 86$ & 6.7 & 24.1 & 67.1 & 10.2 & 6.6 & 14 \\
\hline $3 / 2 / 86$ & 8.7 & 19.9 & 73.2 & 13.2 & 5.5 & 13 \\
\hline $3 / 16 / 86$ & 1.9 & 19.4 & 15.3 & 2.8 & 5.4 & 14 \\
\hline $3 / 30 / 86$ & 4.8 & 18.6 & 38.6 & 7.4 & 5.2 & 14 \\
\hline $4 / 13 / 86$ & $\mathrm{NA}$ & NA & NA & NA & NA & 7 \\
\hline & Mean $=\overline{8.7}$ & $n=\overrightarrow{22.5}$ & $\widehat{1435}$ & $11=225.8$ & $=\overline{6.2}$ & \\
\hline
\end{tabular}


Site ID 41111-151 Thermal Performance

\begin{tabular}{|c|c|c|c|c|c|c|}
\hline $\begin{array}{l}\text { Time Period } \\
\text { Start Date }\end{array}$ & $\begin{array}{c}\text { Mean } \\
\text { Utilization for } \\
\text { Time Period } \\
\end{array}$ & $\begin{array}{l}\text { Mean } \Delta T \text { for } \\
\text { Time Period, } \\
{ }^{\circ} \mathrm{F} \\
\end{array}$ & $\begin{array}{l}\text { Mean } Q_{\text {say }} \\
\text { (sensibie), } \\
\text { kWh/period } \\
\end{array}$ & $\begin{array}{l}\text { Mean AAHX } \\
\text { Energy } \\
\text { Consumption, } \\
\text { kWh/period } \\
\end{array}$ & $\mathrm{Q}_{\mathrm{Sav} / \mathrm{AHE}}$ & $\begin{array}{c}\text { Number of } \\
\text { Days with } \\
\text { Data in Period }\end{array}$ \\
\hline $9 / 1 / 85$ & 3.8 & 17.1 & 22.5 & 7.6 & 3.0 & 14 \\
\hline $9 / 15 / 85$ & 3.3 & 20.1 & 22.4 & 6.6 & 3.4 & 13 \\
\hline $9 / 29 / 85$ & 4.5 & 21.9 & 33.2 & 9.2 & 3.6 & 14 \\
\hline $10 / 13 / 85$ & 5.3 & 20.4 & 36.6 & 10.7 & 3.4 & 12 \\
\hline $10 / 27 / 85$ & 2.1 & 24.2 & 16.7 & 4.2 & 3.9 & 13 \\
\hline $11 / 10 / 85$ & 1.8 & 38.3 & 21.2 & 3.6 & 5.9 & 14 \\
\hline $11 / 24 / 85$ & 1.3 & 38.5 & 15.4 & 2.6 & 5.9 & 14 \\
\hline $12 / 8 / 85$ & 2.5 & 35.2 & 28.0 & 5.1 & 5.5 & 14 \\
\hline $12 / 22 / 85$ & 2.8 & 32.2 & 28.1 & 5.6 & 5.0 & 13 \\
\hline $1 / 5 / 86$ & 2.4 & 23.8 & 18.5 & 4.8 & 3.9 & 13 \\
\hline $1 / 19 / 86$ & 3.1 & 25.6 & 26.4 & 6.4 & 4.1 & 13 \\
\hline $2 / 2 / 86$ & 3.3 & 30.4 & 32.1 & 6.7 & 4.8 & 14 \\
\hline $2 / 16 / 86$ & 5.8 & 25.6 & 48.9 & 11.8 & 4.1 & 12 \\
\hline $3 / 2 / 86$ & 5.1 & 22.2 & 38.1 & 10.4 & 3.7 & 14 \\
\hline $3 / 16 / 86$ & NA & NA & NA & NA & NA & 7 \\
\hline $3 / 30 / 86$ & 4.2 & 21.9 & 30.5 & 8.4 & 3.6 & 12 \\
\hline $4 / 13 / 86$ & 1.4 & 20.4 & 9.6 & 2.8 & 3.4 & 14 \\
\hline & $\mathrm{an}=\overline{3.3}$ & $=26.1$ & $=4 \overline{55}$ & $=113$ & $n=\overline{4.2}$ & \\
\hline
\end{tabular}




\section{Site ID 41111-178 Thermal Performance}

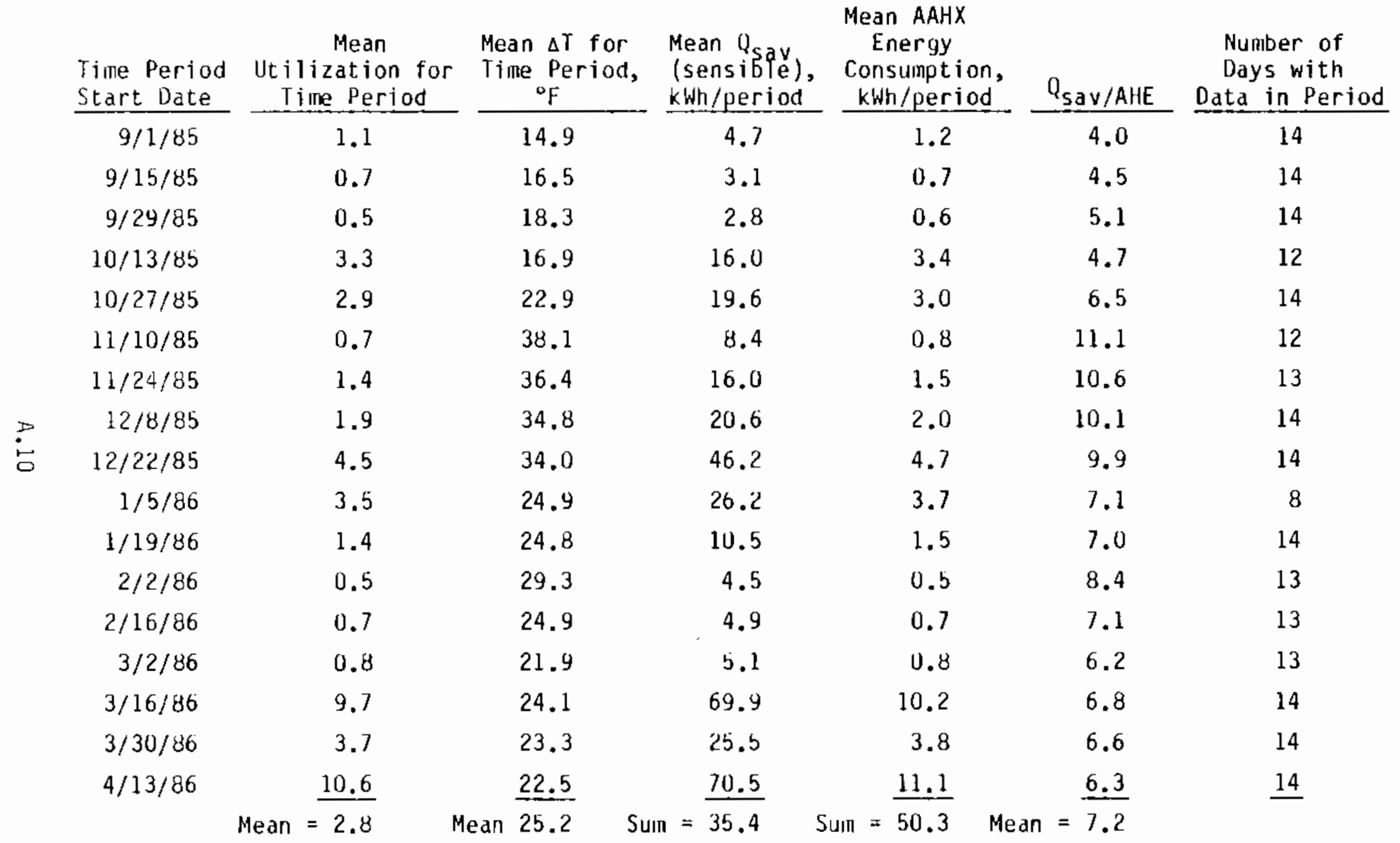


Site ID 41111-209 Thermal Performance

\begin{tabular}{|c|c|c|c|c|c|c|}
\hline $\begin{array}{l}\text { Time Period } \\
\text { Start Date }\end{array}$ & $\begin{array}{c}\text { Mean } \\
\text { Utilization for } \\
\text { Time Period } \\
\end{array}$ & $\begin{array}{l}\text { Mean } \Delta T \text { for } \\
\text { Time Period, } \\
{ }^{\circ} \mathrm{F} \\
\end{array}$ & $\begin{array}{l}\text { Mean } Q_{\text {sav }} \\
\text { (sensible), } \\
\text { kwh/period }\end{array}$ & $\begin{array}{l}\text { Mean AAHX } \\
\text { Energy } \\
\text { Consumption, } \\
\text { kWh/period } \\
\end{array}$ & $\mathrm{Q}_{\text {Sav/AHE }}$ & $\begin{array}{c}\text { Number of } \\
\text { Days with } \\
\text { Data in Period } \\
\end{array}$ \\
\hline $9 / 1 / 85$ & NA & NA & NA & NA & NA & 0 \\
\hline $9 / 15 / 85$ & NA & NA & $N A$ & $N A$ & NA & 0 \\
\hline $9 / 29 / 85$ & NA & NA & NA & $N A$ & NA & 0 \\
\hline $10 / 13 / 85$ & NA & NA & NA & NA & NA & 0 \\
\hline $10 / 27 / 85$ & NA & NA & NA & NA & NA & 0 \\
\hline $11 / 10 / 85$ & NA & NA & $N A$ & NA & NA & 0 \\
\hline $11 / 24 / 85$ & 0.2 & 30.5 & 1.0 & 0.5 & 2.1 & 10 \\
\hline $12 / 8 / 85$ & 0.0 & 30.9 & 0.0 & 0.7 & NA & 14 \\
\hline $12 / 22 / 85$ & 0.3 & 28.7 & 1.5 & 0.7 & 2.0 & 13 \\
\hline $1 / 5 / 86$ & 0.0 & 20.6 & 0.1 & 0.1 & 1.5 & 13 \\
\hline $1 / 19 / 86$ & 0.1 & 21.7 & 0.5 & 0.3 & 1.6 & 13 \\
\hline $2 / 2 / 86$ & 0.2 & 26.7 & 1.0 & 0.5 & 1.9 & 14 \\
\hline $2 / 16 / 86$ & 0.0 & 22.1 & 0.0 & 0.0 & NA & 11 \\
\hline $3 / 2 / 86$ & 0.6 & 18.9 & 2.0 & 1.4 & 1.4 & 13 \\
\hline $3 / 16 / 86$ & 0.0 & $N A$ & NA & 0.1 & NA & 7 \\
\hline $3 / 30 / 86$ & 0.1 & 17.9 & 0.3 & 0.2 & 1.4 & 12 \\
\hline $4 / 13 / 86$ & 0.2 & 17.8 & 0.4 & 0.3 & 1.4 & 13 \\
\hline & $\mathrm{n}=0.2$ & $n=23.6$ & $u m=N A$ & Suln $=N A$ & $=1.7$ & \\
\hline
\end{tabular}




\section{Site ID 41111-211 Thermal Performance}

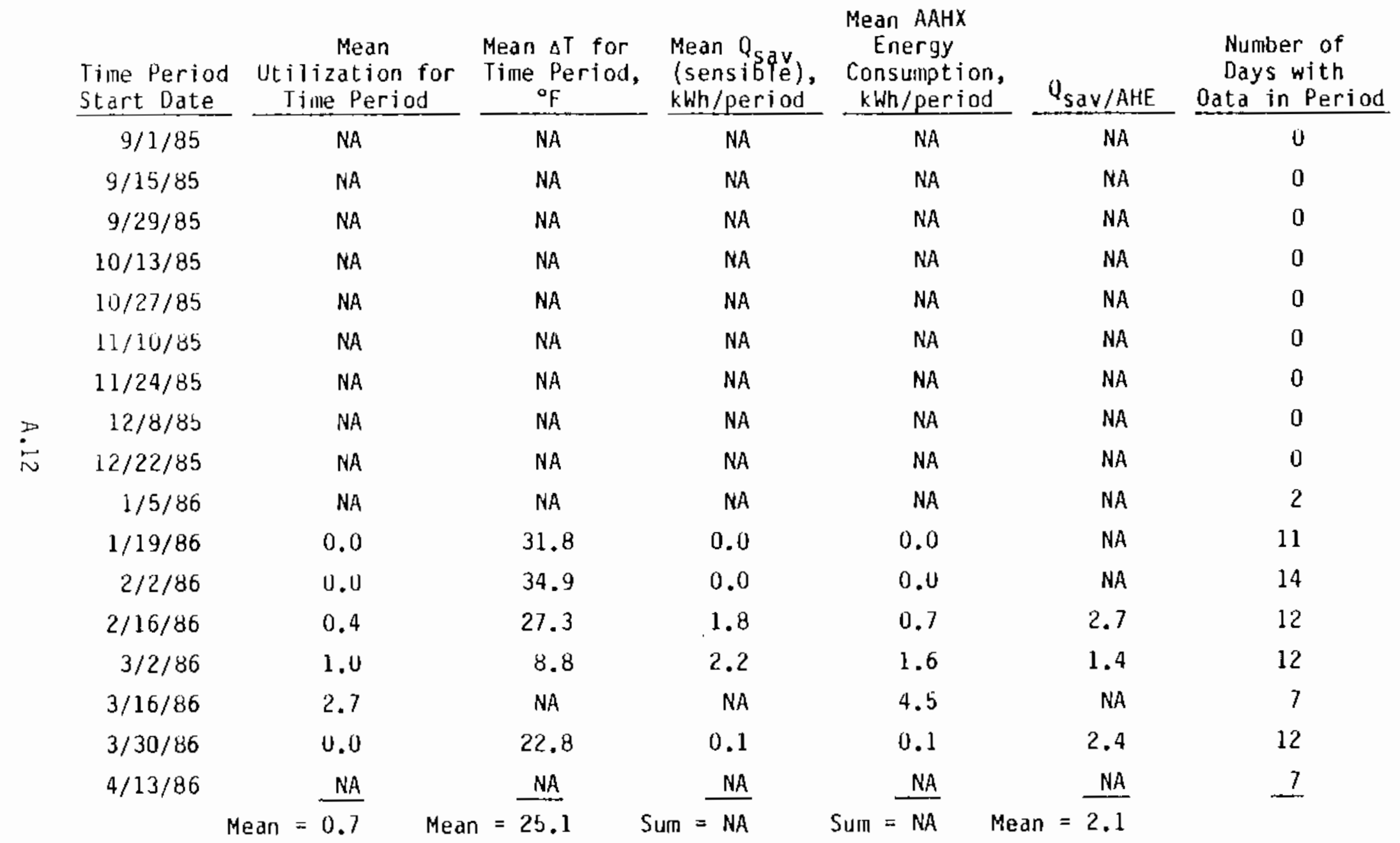


Site ID 41111-215 Therma I Performance

\begin{tabular}{|c|c|c|c|c|c|c|}
\hline $\begin{array}{l}\text { Time Period } \\
\text { Start Date }\end{array}$ & $\begin{array}{c}\text { Mean } \\
\text { Utilization for } \\
\text { Time Period } \\
\end{array}$ & $\begin{array}{l}\text { Mean } \Delta T \text { for } \\
\text { Time Period, } \\
\text { of } \mathrm{F}\end{array}$ & $\begin{array}{l}\text { Mean } Q_{\text {sav }} \\
\text { (sensible), } \\
\text { kWh/period } \\
\end{array}$ & $\begin{array}{l}\text { Mean AAHX } \\
\text { Energy } \\
\text { Consumption, } \\
\text { kWh/period } \\
\end{array}$ & $Q_{\text {sav } / A H E}$ & $\begin{array}{c}\text { Number of } \\
\text { Oays with } \\
\text { Data in Period }\end{array}$ \\
\hline $9 / 1 / 85$ & NA & NA & NA & NA & NA & NA \\
\hline $9 / 15 / 85$ & NA & NA & NA & NA & NA & NA \\
\hline $9 / 29 / 85$ & NA & NA & NA & NA & NA & NA \\
\hline $10 / 13 / 85$ & NA & NA & NA & NA & NA & NA \\
\hline $10 / 27 / 85$ & NA & NA & NA & NA & NA & NA \\
\hline $11 / 10 / 85$ & NA & NA & NA & NA & $\mathrm{NA}$ & NA \\
\hline $11 / 24 / 85$ & 0.5 & 36.7 & 2.6 & 0.9 & 2.9 & 14 \\
\hline $12 / 8 / 85$ & 8.0 & 34.6 & 42.8 & 15.4 & 2.8 & 14 \\
\hline $12 / 22 / 85$ & 1.7 & 33.6 & 8.9 & 3.3 & 2.7 & 13 \\
\hline $1 / 5 / 86$ & 4.3 & 25.8 & 19.2 & 8.2 & 2.3 & 12 \\
\hline $1 / 19 / 86$ & 3.7 & 26.0 & 16.9 & 7.2 & 2.3 & 13 \\
\hline $2 / 2 / 86$ & 0.6 & 31.2 & 3.1 & 1.2 & 2.6 & 14 \\
\hline $2 / 16 / 86$ & 1.1 & 26.3 & 4.8 & 2.0 & 2.4 & 12 \\
\hline $3 / 2 / 86$ & 1.0 & 20.8 & 4.0 & 2.0 & 2.1 & 12 \\
\hline $3 / 16 / 86$ & 3.2 & NA & NA & 6.2 & NA & 7 \\
\hline $3 / 30 / 86$ & 23.1 & 18.9 & 88.5 & 44.3 & 2.0 & 12 \\
\hline $4 / 13 / 86$ & 21.2 & 20.4 & 84.2 & 40.7 & 2.0 & 14 \\
\hline & Mean $=6.2$ & $n=27.4$ & um $=N A$ & Sum $=N A$ & $n=2.4$ & \\
\hline
\end{tabular}


Site ID 41111-217 Thermal Performance

\begin{tabular}{|c|c|c|c|c|c|c|}
\hline $\begin{array}{l}\text { Time Period } \\
\text { Start Date }\end{array}$ & $\begin{array}{c}\text { Mean } \\
\text { Utilization for } \\
\text { Time Period } \\
\end{array}$ & $\begin{array}{l}\text { Mean } \Delta T \text { for } \\
\text { Time Period, } \\
{ }^{\circ} \mathrm{F} \\
\end{array}$ & $\begin{array}{l}\text { Mean Qsav } \\
\text { (sensible), } \\
\text { kWh/period }\end{array}$ & $\begin{array}{l}\text { Mean AAHX } \\
\text { Energy } \\
\text { Consumption, } \\
\text { kWh/period } \\
\end{array}$ & $Q_{\text {SaV } / A H E}$ & $\begin{array}{c}\text { Number of } \\
\text { Days with } \\
\text { Data in Period }\end{array}$ \\
\hline $9 / 1 / 85$ & NA & NA & NA & NA & NA & NA \\
\hline $9 / 15 / 85$ & NA & NA & NA & NA & NA & NA \\
\hline $9 / 29 / 85$ & NA & NA & NA & NA & NA & NA \\
\hline $10 / 13 / 85$ & NA & NA & NA & NA & NA & NA \\
\hline $10 / 27 / 85$ & NA & NA & NA & NA & NA & NA \\
\hline $11 / 10 / 85$ & NA & NA & NA & NA & NA & 4 \\
\hline $11 / 24 / 85$ & NA & NA & NA & NA & NA & 6 \\
\hline $12 / 8 / 85$ & 0.7 & 32.4 & 5.7 & 1.5 & 3.7 & 14 \\
\hline $12 / 22 / 85$ & 0.8 & 29.9 & 5.6 & 1.6 & 3.5 & 13 \\
\hline $1 / 5 / 86$ & 0.5 & 22.1 & 2.6 & 0.9 & 2.8 & 13 \\
\hline $1 / 19 / 86$ & 0.1 & 23.9 & 0.5 & 0.2 & 2.9 & 13 \\
\hline $2 / 2 / 86$ & 0.0 & 27.6 & 0.2 & 0.0 & 3.3 & 14 \\
\hline $2 / 16 / 86$ & 0.3 & 23.3 & 1.9 & 0.6 & 2.9 & 12 \\
\hline $3 / 2 / 86$ & 0.0 & 19.2 & 0.0 & 0.0 & $N A$ & 11 \\
\hline $3 / 16 / 86$ & 0.0 & NA & NA & 0.0 & NA & 7 \\
\hline $3 / 30 / 86$ & 0.1 & 19.3 & 0.6 & 0.2 & 2.5 & 12 \\
\hline \multirow[t]{2}{*}{$4 / 13 / 86$} & 1.1 & 17.7 & 5.4 & 2.3 & 2.4 & 14 \\
\hline & lean $=0.4$ & $n=\overline{23.9}$ & Sum $=N A$ & $\mathrm{uml}=3.0$ & $a n=N A$ & \\
\hline
\end{tabular}


Site ID 41111-237 Thermal Performance

\begin{tabular}{|c|c|c|c|c|c|c|}
\hline $\begin{array}{l}\text { Time Period } \\
\text { Start Date }\end{array}$ & $\begin{array}{c}\text { Mean } \\
\text { Utilization for } \\
\text { Time Period } \\
\end{array}$ & $\begin{array}{c}\text { Mean } \Delta T \text { for } \\
\text { Time Period, } \\
{ }^{\circ} \mathrm{F}\end{array}$ & $\begin{array}{l}\text { Mean } Q_{\text {sav }} \\
\text { (sensible), } \\
\text { kWh/period } \\
\end{array}$ & $\begin{array}{l}\text { Mean AAHX } \\
\text { Energy } \\
\text { Consumption, } \\
\text { kWh/peri od } \\
\end{array}$ & $Q_{\text {Sav/AHE }}$ & $\begin{array}{c}\text { Number of } \\
\text { Days with } \\
\text { Data in Period }\end{array}$ \\
\hline $9 / 1 / 85$ & 0.0 & 17.6 & 0.0 & 0.0 & 0.0 & 13 \\
\hline $9 / 15 / 85$ & 0.0 & 19.3 & 0.0 & 0.0 & 0.0 & 13 \\
\hline $9 / 29 / 85$ & 0.0 & 20.5 & 0.0 & 0.0 & 0.0 & 13 \\
\hline $10 / 13 / 85$ & 0.0 & 18.8 & 0.0 & 0.0 & 0.0 & 14 \\
\hline $10 / 27 / 85$ & 0.0 & 24.9 & 0.0 & 0.0 & 0.0 & 13 \\
\hline $11 / 10 / 85$ & 0.0 & 34.1 & 0.0 & 0.0 & 0.0 & 11 \\
\hline $11 / 24 / 85$ & NA & NA & NA & NA & NA & 1 \\
\hline $12 / 8 / 85$ & 0.0 & 35.1 & 0.0 & 0.0 & 0.0 & 13 \\
\hline $12 / 22 / 85$ & 0.0 & 36.2 & 0.0 & 0.0 & 0.0 & 14 \\
\hline $1 / 5 / 86$ & NA & NA & NA & NA & NA & 0 \\
\hline $1 / 19 / 86$ & NA & NA & NA & NA & NA & 7 \\
\hline $2 / 2 / 86$ & 2.4 & 31.2 & 12.6 & 2.7 & 4.7 & 14 \\
\hline $2 / 16 / 86$ & 8.5 & 27.0 & 39.1 & 9.5 & 4.1 & 14 \\
\hline $3 / 2 / 86$ & 7.5 & 23.4 & 30.6 & 8.4 & 3.6 & 14 \\
\hline $3 / 16 / 86$ & 10.5 & 23.4 & 42.9 & 11.8 & 3.6 & 14 \\
\hline $3 / 30 / 86$ & 6.8 & 24.0 & 28.5 & 7.7 & 3.7 & 13 \\
\hline $4 / 13 / 86$ & NA & NA & NA & NA & $\underline{N A}$ & 4 \\
\hline & Mean $=2.7$ & $n=25.8$ & $i u m=N A$ & Sum $=N A$ & $a n=N A$ & \\
\hline
\end{tabular}


Site ID 41311-189 Thermal Performance

\begin{tabular}{|c|c|c|c|c|c|c|}
\hline $\begin{array}{l}\text { Time Period } \\
\text { Start Date } \\
\end{array}$ & $\begin{array}{c}\text { Mean } \\
\text { Utilization for } \\
\text { Time Period } \\
\end{array}$ & $\begin{array}{c}\text { Mean } \Delta T \text { for } \\
\text { Time Period, } \\
\text { of }\end{array}$ & $\begin{array}{l}\text { Mean } Q_{\text {sav }} \\
\text { (sensibPe), } \\
\text { kWh/period }\end{array}$ & $\begin{array}{l}\text { Mean AAHX } \\
\text { Energy } \\
\text { Consumption, } \\
\text { kwh/period }\end{array}$ & $Q_{\text {Sav/AHE }}$ & $\begin{array}{c}\text { Number of } \\
\text { Days with } \\
\text { Data in Period } \\
\end{array}$ \\
\hline $9 / 1 / 85$ & 4.7 & 14.2 & 20.0 & 7.7 & 2.6 & 14 \\
\hline $9 / 15 / 85$ & 4.6 & 14.5 & 19.9 & 7.6 & 2.6 & 14 \\
\hline $9 / 29 / 85$ & 4.9 & 19.6 & 26.7 & 8.1 & 3.3 & 14 \\
\hline $10 / 13 / 85$ & 4.5 & 19.8 & 24.5 & 7.4 & 3.3 & 10 \\
\hline $10 / 27 / 85$ & 4.5 & 25.2 & 30.0 & 7.5 & 4.0 & 13 \\
\hline $11 / 10 / 85$ & 4.5 & 39.6 & 43.5 & 7.4 & 5.9 & 14 \\
\hline $11 / 24 / 85$ & 5.0 & 39.9 & 49.1 & 8.3 & 5.9 & 12 \\
\hline $12 / 8 / 85$ & 4.4 & 38.6 & 41.6 & 7.2 & 5.7 & 14 \\
\hline $12 / 22 / 85$ & 1.9 & 37.1 & 17.0 & 3.1 & 5.5 & 14 \\
\hline $1 / 5 / 86$ & 2.2 & 25.2 & 14.3 & 3.6 & 4.0 & 13 \\
\hline $1 / 19 / 86$ & 2.2 & 26.5 & 15.2 & 3.6 & 4.2 & 14 \\
\hline $2 / 2 / 86$ & 2.1 & 33.4 & 17.5 & 3.5 & 5.1 & 13 \\
\hline $2 / 16 / 86$ & 2.2 & 26.7 & 15.1 & 3.6 & 4.2 & 14 \\
\hline $3 / 2 / 86$ & 2.0 & 22.1 & 11.9 & 3.3 & 3.6 & 13 \\
\hline $3 / 16 / 86$ & NA & NA & NA & NA & NA & 7 \\
\hline $3 / 30 / 86$ & NA & NA & NA & NA & NA & 0 \\
\hline $4 / 13 / 86$ & NA & NA & NA & NA & NA & 0 \\
\hline & $\operatorname{ean}=3.5$ & $n=27.3$ & $=421$ & $=99$ & $n=4.3$ & \\
\hline
\end{tabular}


Site ID 42111-021 Thermal Performance

\begin{tabular}{|c|c|c|c|c|c|c|}
\hline $\begin{array}{l}\text { Time Period } \\
\text { Start Date }\end{array}$ & $\begin{array}{c}\text { Mean } \\
\text { Utilization for } \\
\text { Iime Period } \\
\end{array}$ & $\begin{array}{l}\text { Mean } \Delta T \text { for } \\
\text { Time Period, } \\
{ }^{\circ} \mathrm{F}\end{array}$ & $\begin{array}{l}\text { Mean Qsav } \\
\text { (sensible), } \\
\text { kWh/period }\end{array}$ & $\begin{array}{l}\text { Mean AAHX } \\
\text { Energy } \\
\text { Consumption, } \\
\text { kWh/period } \\
\end{array}$ & $\mathrm{Q}_{\mathrm{Sav} / \mathrm{AHE}}$ & $\begin{array}{c}\text { Number of } \\
\text { Days with } \\
\text { Data in Period }\end{array}$ \\
\hline $9 / 1 / 85$ & 0.6 & 17.8 & 1.8 & 1.0 & 1.7 & 13 \\
\hline $9 / 15 / 85$ & 0.2 & 25.8 & 0.7 & 0.4 & 2.0 & 14 \\
\hline $9 / 29 / 85$ & 1.0 & 31.5 & 4.1 & 1.8 & 2.2 & 13 \\
\hline $10 / 13 / 85$ & 0.7 & 28.8 & 3.0 & 1.4 & 2.1 & 14 \\
\hline $10 / 27 / 85$ & 1.3 & 35.0 & 5.7 & 2.4 & 2.4 & 13 \\
\hline $11 / 10 / 85$ & 1.3 & 54.1 & 7.7 & 2.5 & 3.0 & 14 \\
\hline $11 / 24 / 85$ & 1.8 & 57.5 & 11.0 & 3.5 & 3.2 & 14 \\
\hline $12 / 8 / 85$ & 1.3 & 50.9 & 7.4 & 2.5 & 2.9 & 14 \\
\hline $12 / 22 / 85$ & 1.3 & 49.6 & 7.1 & 2.4 & 2.9 & 14 \\
\hline $1 / 5 / 86$ & 0.9 & 43.3 & 4.5 & 1.7 & 2.7 & 13 \\
\hline $1 / 19 / 86$ & 2.3 & 40.6 & 11.4 & 4.5 & 2.6 & 14 \\
\hline $2 / 2 / 86$ & 2.0 & 44.8 & 10.6 & 3.9 & 2.7 & 14 \\
\hline $2 / 16 / 86$ & 1.8 & 37.1 & 8.6 & 3.5 & 2.4 & 14 \\
\hline $3 / 2 / 86$ & 0.8 & 31.7 & 3.3 & 1.5 & 2.2 & 14 \\
\hline $3 / 16 / 86$ & 0.5 & 28.6 & 1.9 & 0.9 & 2.1 & 14 \\
\hline $3 / 30 / 86$ & 0.2 & 26.8 & 0.7 & 0.4 & 2.0 & 7 \\
\hline $4 / 13 / 86$ & NA & NA & NA & NA & NA & $\underline{N A}$ \\
\hline & $\operatorname{ean}=\overline{1.1}$ & $n=\overline{37.7}$ & $=\overline{101.9}$ & $u_{m} m=36.3$ & $n=2.5$ & \\
\hline
\end{tabular}




\section{Site I0 42111-144 Thermal Performance}

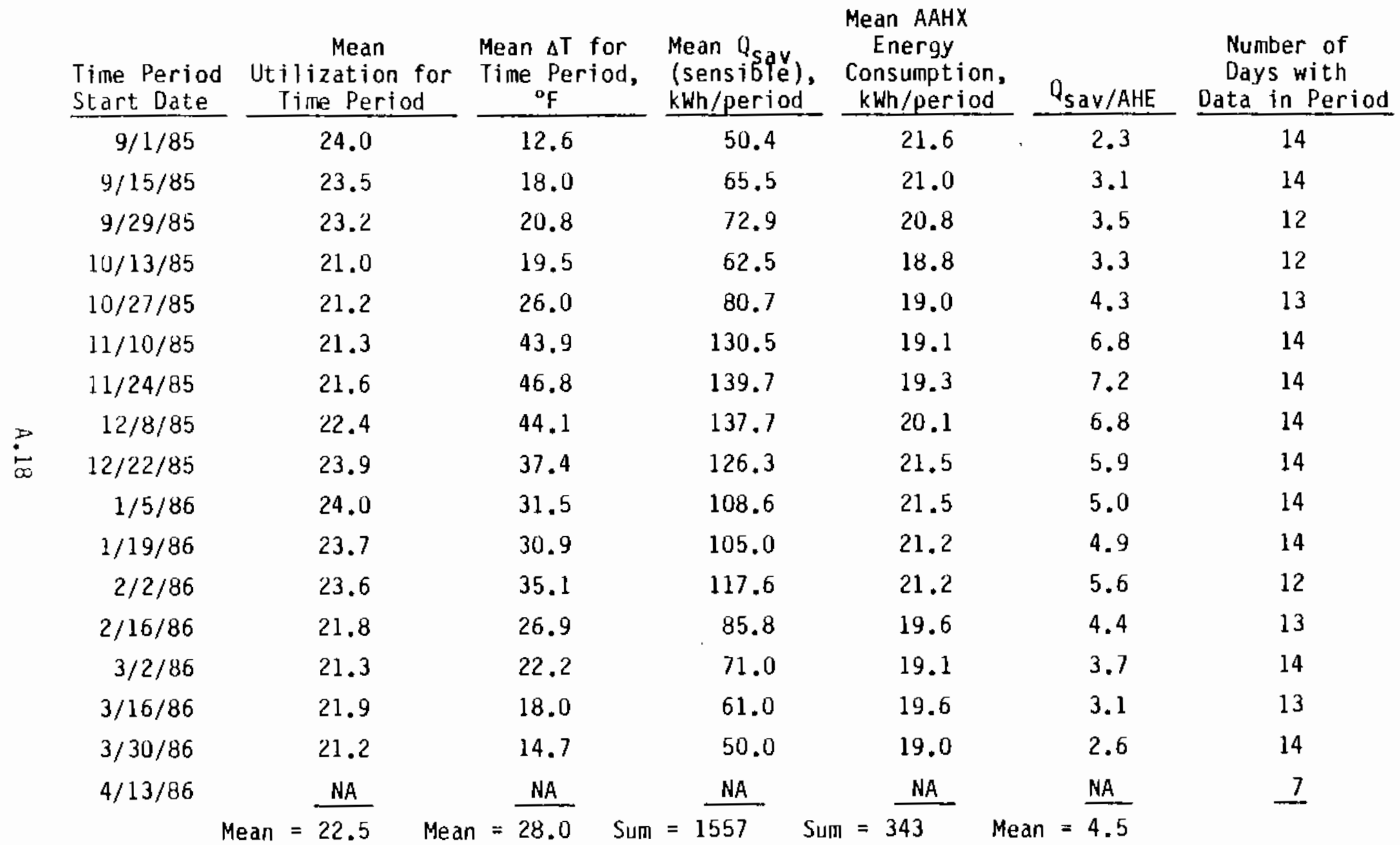


Site ID 42211-145 Thermal Performance

\begin{tabular}{|c|c|c|c|c|c|c|}
\hline $\begin{array}{l}\text { Time Period } \\
\text { Start Date } \\
\end{array}$ & $\begin{array}{c}\text { Mean } \\
\text { Utilization for } \\
\text { Time Period } \\
\end{array}$ & $\begin{array}{l}\text { Mean } \Delta T \text { for } \\
\text { Time Period, } \\
\text { o } \mathrm{F} \\
\end{array}$ & $\begin{array}{l}\text { Mean } 0_{\text {say }} \\
\text { (sensible), } \\
\text { kwh/period }\end{array}$ & $\begin{array}{l}\text { Mean AAHX } \\
\text { Energy } \\
\text { Consumption, } \\
\text { kWh/period } \\
\end{array}$ & $0_{\text {Sav/AHE }}$ & $\begin{array}{c}\text { Number of } \\
\text { Days with } \\
\text { Data in Period }\end{array}$ \\
\hline $9 / 1 / 85$ & $N A$ & NA & NA & NA & NA & 0 \\
\hline $9 / 15 / 85$ & NA & NA & NA & NA & NA & 0 \\
\hline $9 / 29 / 85$ & NA & NA & NA & NA & NA & 0 \\
\hline $10 / 13 / 85$ & NA & NA & NA & NA & NA & 0 \\
\hline $10 / 27 / 85$ & NA & NA & NA & NA & NA & 0 \\
\hline $11 / 10 / 8 b$ & NA & NA & NA & NA & NA & 0 \\
\hline $11 / 24 / 85$ & NA & NA & NA & NA & NA & 0 \\
\hline $12 / 8 / 85$ & NA & NA & NA & NA & NA & 0 \\
\hline $12 / 22 / 85$ & NA & NA & NA & NA & NA & 0 \\
\hline $1 / 5 / 86$ & NA & NA & NA & NA & NA & 7 \\
\hline $1 / 19 / 86$ & NA & NA & NA & NA & NA & 14 \\
\hline $2 / 2 / 86$ & 10.3 & 35.1 & 67.4 & 8.0 & 8.3 & 14 \\
\hline $2 / 16 / 86$ & 3.3 & 27.9 & 18.0 & 2.6 & 6.9 & 12 \\
\hline $3 / 2 / 86$ & 14.4 & 24.3 & 68.8 & 11.3 & 6.1 & 12 \\
\hline $3 / 16 / 86$ & 4.7 & 20.3 & 19.3 & 3.7 & 5.3 & 14 \\
\hline $3 / 30 / 86$ & 5.5 & 19.6 & 22.1 & 4.3 & 5.1 & 7 \\
\hline $4 / 13 / 86$ & NA & NA & NA & NA & $\underline{N A}$ & $\underline{N A}$ \\
\hline & Mean $=7.6$ & $=25.4$ & $u m=N A$ & Sum $=N A$ & $n=6.4$ & \\
\hline
\end{tabular}


Site ID 42211-304 Thermal Performance

\begin{tabular}{|c|c|c|c|c|c|c|}
\hline $\begin{array}{l}\text { Time Period } \\
\text { Start Date }\end{array}$ & $\begin{array}{c}\text { Mean } \\
\text { Utilization for } \\
\text { Time Period } \\
\end{array}$ & $\begin{array}{c}\text { Mean } \Delta T \text { for } \\
\text { Time Period, } \\
{ }^{\circ} \mathrm{F} \\
\end{array}$ & $\begin{array}{l}\text { Mean } Q_{\text {sav }} \\
\text { (sensible), } \\
\text { kwh/perjod }\end{array}$ & $\begin{array}{l}\text { Mean AAHX } \\
\text { Energy } \\
\text { Consumption, } \\
\text { kwh/period } \\
\end{array}$ & $Q_{\text {sav/AHE }}$ & $\begin{array}{c}\text { Number of } \\
\text { Days with } \\
\text { Data in Period } \\
\end{array}$ \\
\hline $9 / 1 / 85$ & NA & NA & NA & NA & NA & 0 \\
\hline $9 / 15 / 85$ & NA & NA & NA & NA & NA & 0 \\
\hline $9 / 29 / 85$ & NA & NA & NA & NA & $N A$ & 0 \\
\hline $10 / 13 / 85$ & NA & NA & NA & NA & NA & 0 \\
\hline $10 / 27 / 85$ & NA & NA & NA & NA & NA & 0 \\
\hline $11 / 10 / 85$ & NA & NA & NA & NA & NA & 0 \\
\hline $11 / 24 / 85$ & NA & NA & NA & NA & NA & 0 \\
\hline $12 / 8 / 85$ & NA & NA & NA & NA & NA & 4 \\
\hline $12 / 22 / 85$ & NA & NA & NA & NA & NA & 3 \\
\hline $1 / 5 / 86$ & 15.4 & 36.7 & 86.1 & 22.5 & 3.8 & 14 \\
\hline $1 / 19 / 86$ & 15.3 & 33.9 & 81.7 & 22.3 & 3.7 & 14 \\
\hline $2 / 2 / 86$ & 14.2 & 39.1 & 82.7 & 20.7 & 4.0 & 14 \\
\hline $2 / 16 / 86$ & 13.8 & 31.7 & 70.4 & 20.0 & 3.5 & 14 \\
\hline $3 / 2 / 86$ & 16.2 & 28.4 & 77.8 & 23.6 & 3.3 & 14 \\
\hline $3 / 16 / 86$ & 16.8 & 23.5 & 72.9 & 24.4 & 3.0 & 12 \\
\hline $3 / 30 / 86$ & 15.1 & 24.6 & 67.2 & 22.0 & 3.1 & 14 \\
\hline $4 / 13 / 86$ & NA & NA & NA & NA & NA & 7 \\
\hline & $n=15.3$ & $=31.2$ & $u m=N A$ & Sum $=N A$ & $n=3.5$ & \\
\hline
\end{tabular}




\section{Site ID 42311-224 Thermal Performance}

\begin{tabular}{|c|c|c|c|c|c|c|}
\hline $\begin{array}{l}\text { Time Period } \\
\text { Start Date }\end{array}$ & $\begin{array}{c}\text { Mean } \\
\text { Utilization for } \\
\text { Time_Period } \\
\end{array}$ & $\begin{array}{l}\text { Mean } \Delta T \text { for } \\
\text { Time Period, } \\
{ }^{\circ} \mathrm{F} \\
\end{array}$ & $\begin{array}{l}\text { Mean Qsav } \\
\text { (sensible), } \\
\text { kWh/period }\end{array}$ & $\begin{array}{c}\text { Mean AAHX } \\
\text { Energy } \\
\text { Consumption, } \\
\text { kwh/period }\end{array}$ & $Q_{\text {Sav/AHE }}$ & $\begin{array}{c}\text { Number of } \\
\text { Days with } \\
\text { Data in Period }\end{array}$ \\
\hline $9 / 1 / 85$ & NA & NA & $\mathrm{NA}$ & NA & NA & 0 \\
\hline $9 / 15 / 85$ & NA & NA & NA & NA & NA & 0 \\
\hline $9 / 29 / 85$ & NA & NA & NA & NA & NA & 0 \\
\hline $10 / 13 / 85$ & NA & NA & NA & NA & NA & 0 \\
\hline $10 / 27 / 85$ & NA & NA & NA & $N A$ & NA & 0 \\
\hline $11 / 10 / 85$ & NA & NA & NA & NA & $N A$ & 5 \\
\hline $11 / 24 / 85$ & 21.5 & 54.2 & 164.8 & 19.3 & 8.5 & 12 \\
\hline $12 / 8 / 85$ & 17.6 & 54.2 & 134.4 & 15.8 & 8.5 & 9 \\
\hline $12 / 22 / 85$ & NA & NA & NA & NA & NA & 3 \\
\hline $1 / 5 / 86$ & 18.7 & 40.1 & 117.5 & 16.7 & 7.0 & 12 \\
\hline $1 / 19 / 86$ & 9.9 & 38.7 & 60.8 & 8.9 & 6.9 & 11 \\
\hline $2 / 2 / 86$ & 14.2 & 44.2 & 94.9 & 12.7 & 7.5 & 12 \\
\hline $2 / 16 / 86$ & 16.4 & 33.9 & 93.7 & 14.7 & 6.4 & 14 \\
\hline $3 / 2 / 86$ & 18.7 & 30.2 & 100.1 & 16.8 & 5.9 & 14 \\
\hline $3 / 16 / 86$ & 18.3 & 27.7 & 93.4 & 16.4 & 5.7 & 14 \\
\hline $3 / 30 / 86$ & 16.3 & 28.4 & 84.4 & 14.6 & 5.8 & 13 \\
\hline $4 / 13 / 86$ & 15.6 & 31.6 & 85.5 & 14.0 & 6.1 & 5 \\
\hline & ean $=\overline{16.7}$ & $1=38.3$ & $u m=N A$ & Surn $=N A$ & $=6.8$ & \\
\hline
\end{tabular}


. 
APPENDIX B

DEFINITION OF ID NUMBER 


\section{DEFINITION OF ID NUMBER}

The site ID number includes information on a site. This appendix presents an explanation of the various components of the ID number. A sample ID number is shown in Figure $B .1$.

Each digit of the ID number describes a site characteristic using a numerical code. The digits represent the following characteristics:

- State containing site

1 = Idaho

2 = Montana

$3=$ Oregon

4 = Washington

- Cljmate zone

$1=$ Climate zone one

2 = Climate zone two

$3=$ Climate zone three

- Matching

1 = matched pair

2 = unmatched pair

- MCS dwelling type

$1=$ MCS dwelling

2 = control dwelling

- $S / M$ dwelling type

$1=$ single family

$3=$ multi family

- Site number--a number used to identify the site. 


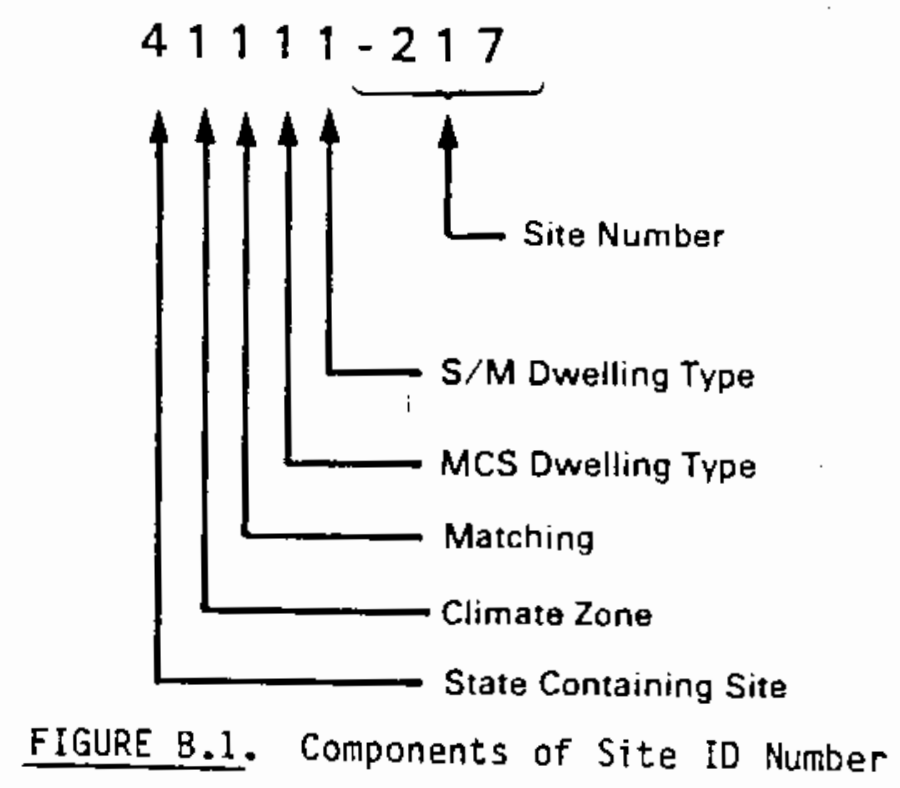




\section{DISTRIBUTION}

No. of

Copjes

OFFSITE

2 DDE/Office of Scientific and Technical Information

2 R. A. Gillman Bonneville Power Administration End-Use Research Section

P.0. Box 3621-RPEE

Portland, OR 97208

M. E. Taylor

Bonneville Power Administration

End-Use Research Section

P.0. Box 3621-RPEE

Portland, OR 97208

S. G. Hauser

Battelle Portland Office

500 NE Multnomah, Suite 650

Portland, OR 97232
No. of

Copies

W. M. Warwick

Battelle Portland Office

500 NE Multnomah, Suite 650

Portland, OR 97232

\section{ONSITE}

12

Pacific Northwest Laboratory

C. C. Connor

R. G. Pratt

W. F. Sandusky (4)

G. M. Stokes

Publishing Coordination

Technical Report Files (5) 
, 